$\mathrm{DOE} / \mathrm{RW}--0221$

TI89 007053

Office of Civilian Radioactive Waste Management

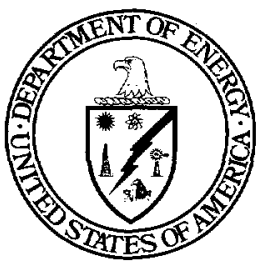

\title{
1988 Bulletin Compilation and Index
}

February 1989

U.S. Department of Energy

Office of Civilian Radioactive Waste Management

Washington, DC 20585 


\section{DISCLAIMER}

This report was prepared as an account of work sponsored by an agency of the United States Government. Neither the United States Government nor any agency thereof, nor any of their employees, make any warranty, express or implied, or assumes any legal liability or responsibility for the accuracy, completeness, or usefulness of any information, apparatus, product, or process disclosed, or represents that its use would not infringe privately owned rights. Reference herein to any specific commercial product, process, or service by trade name, trademark, manufacturer, or otherwise does not necessarily constitute or imply its endorsement, recommendation, or favoring by the United States Government or any agency thereof. The views and opinions of authors expressed herein do not necessarily state or reflect those of the United States Government or any agency thereof. 


\section{DISCLAIMER}

Portions of this document may be illegible in electronic image products. Images are produced from the best available original document. 


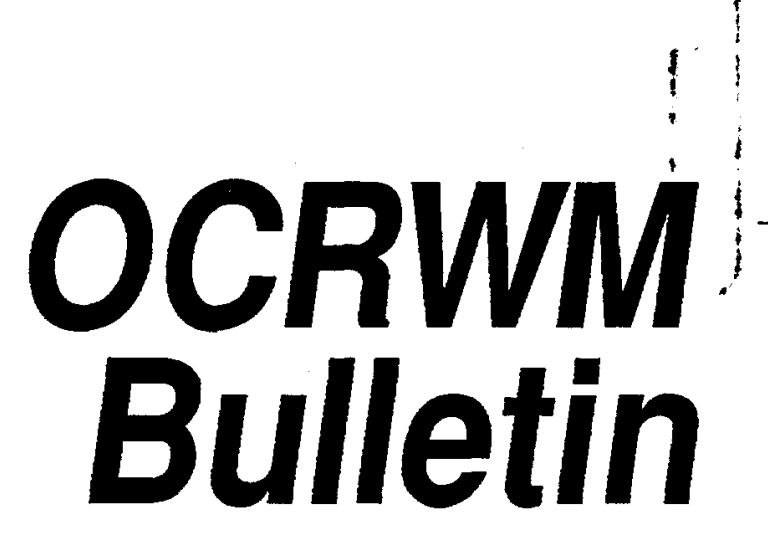

United States Department of Energy Office of Civilian Radioactive Waste Management Washington, $D C 20585$

\section{Introduction}

The OCRWM Bulletin is published by the Department of Energy, Office of Civilian Radioactive Waste Mangement to provide current information about the national program for managing spent fuel and high-level radioactive waste. This document is a compilation of issues from the 1988 calendar year. A table of contents and one index have been provided to assist in finding information contained in this year's Bulletins. The pages have been numbered consecutively at the bottom for easy reference.

\section{Table of Contents}

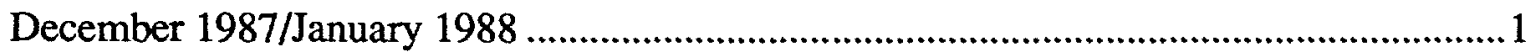

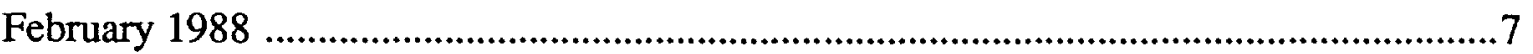

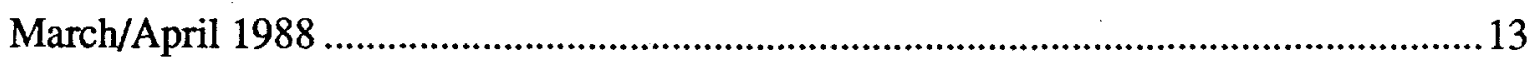

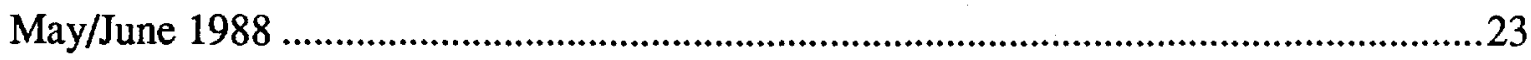

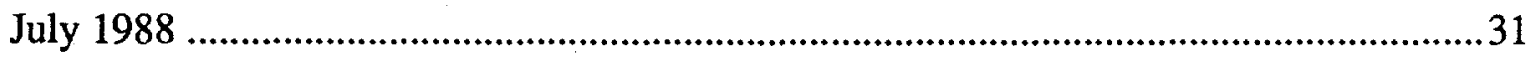

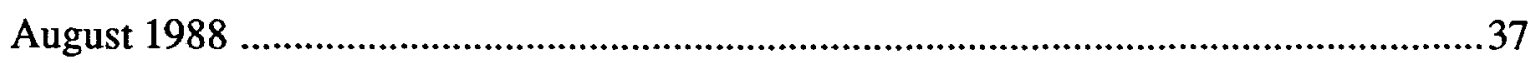

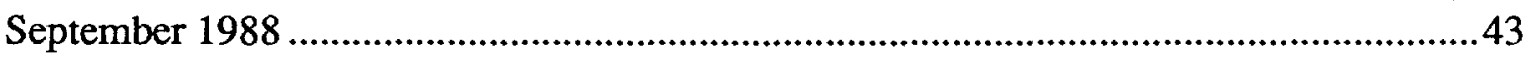

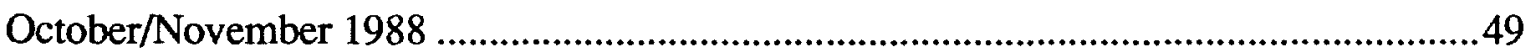

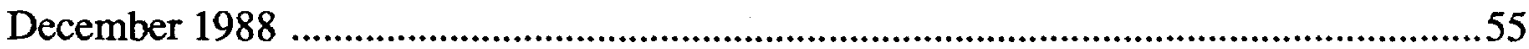

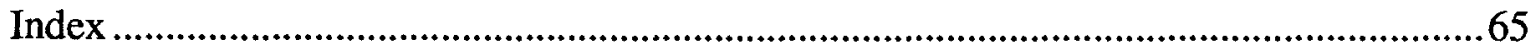




\section{OCRWM Bulletin}

United States Department of Energy

Office of Civilian Radioactive Waste Management

Washington, DC 20585

December 1987/January 1988

\section{Congress Amends Nuclear Waste Policy Act of 1982}

On Dec. 22, 1987, President Reagan signed into law the Budget Reconciliation Act for Fiscal Year 1988 (Public Law 100-203). In establishing the Conference agreement on this legislation, Congress approved a number of amendments to the Nuclear Waste Policy Act of 1982 (NWPA) giving the nuclear waste disposal program dramatic new directions. The following explanation of the Nuclear Waste Policy Amendments Act of 1987 is taken from the statement of the Reconciliation Conference managers.

\section{The First Repository}

(1) The Department of Energy (DOE) is directed to characterize the Yucca Mountain, NV, site for development of the first repository. Drilling of an exploratory shaft at the Yucca Mountain site may begin upon completion of the site characterization plan and public hearings required under the NWPA.

(2) Site-specific activities for the Hanford, WA, and Deaf Smith County, TX, sites shall terminate within 90 days of enactment of the budget reconciliation legislation.

(3) DOE is authorized to site and construct, subject to existing licensing requirements, a deep geologic nuclear waste repository only at the Yucca Mountain site. In the event that the Yucca Mountain site proves unsuitable for use as a repository, DOE is required to terminate site-specific activities and report to Congress.
(4) The provisions of the NWPA pertaining to the application of the National Environmental Policy Act (NEPA) are preserved, except that the existing requirement that the environmental impact statement accompanying DOE's repository siting recommendation consider alternative sites is eliminated. NEPA applies to the redirected program under this Act in the same way as NEPA applied to the NWPA. The conferees do not intend that enactment of the conference substitute result in any change in NEPA application except as expressly provided.

\section{Monitored Retrievable Storage}

(5) DOE's proposal to locate a monitored retrievable storage (MRS) facility is annulled and revoked. DOE is authorized to site, construct and operate one MRS facility as follows:

(a) DOE is authorized to conduct a survey of potentially suitable sites for an MRS facility. In so doing, the Secretary of Energy (the Secretary) may conduct site-specific activities at the sites for the purposes of gathering the information necessary to support a license application. The survey may begin after the MRS commission established by the conference substitute reports to Congress. (b) DOE may select a site from among those surveyed after the Secretary recommends to the President a site for development as a repository.

(c) The selection of a site for an MRS facility shall not require an environmental impact statement but shall be accompanied by an environmental assessment.

(d) At least 6 months prior to selecting a site for an MRS facility, DOE shall notify the affected State or Indian tribe. Prior to selection of an MRS site, DOE shall hold at least one public hearing in the vicinity of such site for the purposes of receiving recommendations of interested parties.

(e) No MRS may be located in Nevada. (continued on page 2)

\section{In This Issue}

\begin{tabular}{|lr|}
\hline \multicolumn{2}{|c|}{ In This Issue ... } \\
\hline $\begin{array}{l}\text { Congress Amends Nuclear Waste } \\
\text { Policy Act of 1982 }\end{array}$ \\
$\begin{array}{l}\text { Amendment to From-Reactor } \\
\text { Cask Development Strategy }\end{array}$ \\
$\begin{array}{l}\text { Science Applications International } \\
\text { Corporation Selected as Contractor } \\
\text { for Licensing Support System }\end{array}$ \\
$\begin{array}{l}\text { Selected Events Calendar } \\
\text { New Publications and Documents }\end{array}$ \\
\hline
\end{tabular}




\section{Congress Amends Nuclear Waste Policy Act of 1982 \\ (continued from page 1)}

(f) When DOE selects an MRS site, the host state may disapprove the selection. The State's disapproval may be overridden by Congress under the expedited procedures contained in the NWPA.

(g) Once a selection is made, the host state may enter into a benefits agreement pursuant to the conference substitute if such State surrenders its right to issue a notice of disapproval.

(h) Construction and operation of an MRS facility is subject to licensing by the Nuclear Regulatory Commission (NRC). The conditions imposed on such license are as follows:

- construction may not begin until a license for construction of a repository is issued by the NRC;

- the quantity of nuclear waste stored in the MRS may not exced 10,000 metric tons until the repository begins accepting nuclear waste;

- the quantity of nuclear waste may not exceed 15,000 metric tons; and

- construction of an MRS facility or acceptance of nuclear waste shall be prohibited during the time a repository license is revoked by the NRC or construction of the repository ceases.

(i) A three-member commission is established for the purposes of reporting to Congress by June 1 , 1989 , on the need for an MRS facility.

\section{The Second Repository}

(6) The requirements of the NWPA for the siting of a second deep geologic repository are repealed. DOE is directed to report to the President and Congress between 2007 and 2010 on the need for a second repository. Site-specific activities with respect to a second site are prohibited unless specifically authorized and appropriated. DOE is directed to terminate research on granite as a repository medium.

\section{The Negotiator}

(7) The President is directed to appoint a Negotiator to seek a State or Indian tribe willing to host a permanent repository or MRS at a suitable site. The Negotiator is authorized to negotiate the terms and conditions (including financial and institutional arrangements) under which the State or Tribe would be willing to host a repository or MRS facility. Congress must approve and enact implementing legislation for an agreement reached by the Negotiator and State or Tribe to take effect. The Negotiator's effort to find a State or Tribe willing to host a repository or MRS facility are independent of, and would proceed in parallel with, DOE's efforts to site a repository at Yucca Mountain, NV, and an MRS facility.

\section{Siting Benefits}

(8) Impact assistance and grants-equalto-taxes provisions of the NWPA are broadened:

(a) to extend technical assistance to affected local governments;

(b) to extend mitigation assistance to cover impacts of site characterization activities; and

(c) to extend financial assistance and grants-equal-to-taxes to affected local governments (including special purpose taxing districts).

(9) DOE is authorized to make payments to Nevada as follows:

(a) \$10 million per year after signing an agreement until the repository begins accepting nuclear waste; and (b) $\$ 20$ million per year after beginning to accept nuclear waste until closure of the repository.

DOE is also authorized to make payments to a state or Indian tribe hosting an MRS facility as follows:

(a) $\$ 5$ million per year after signing an agreement until the facility begins accepting nuclear waste; and

(b) \$10 million per year after beginning to accept nuclear waste until closure of the facility.

A state must waive its right to disapprove siting of a repository or MRS facility and its right to impact mitigation assistance under (8)(b) and (c), but not its right to technical assistance under (8)(a), in order to receive the foregoing payments. Impact assistance for a State or Indian tribe hosting an MRS facility under section 116 or 118 , as affected by section 149 , must be waived.

(10) An 11-member Nuclear Waste Technical Review Board is established to review technical aspects of DOE's nuclear waste program. The Board is authorized to make recommendations to $\mathrm{DOE}$ and Congress.

(11) DOE is prohibited from shipping spent fuel or high-level waste except in packages certified by the NRC. DOE also is required to abide by NRC regulations on advance notification of state and local governments of nuclear waste shipments. In addition, DOE is directed to provide technical assistance and funding for training public safety officials of local governments and Indian tribes pertaining to nuclear waste transportation.

(12) $\mathrm{DOE}$ is directed to study subseabed disposal and the impact of siting the permanent repository in Nevada. (continued on page 3) 


\section{Congress Amends Nuclear Waste Policy Act of 1982 \\ (continued from page 2)}

(13) DOE is directed to give special consideration to proposals from Nevada in siting Federal research projects.

(14) DOE is directed to establish a new Office of Subseabed Research to study subseabed disposal of nuclear waste.

OCRWM is now reviewing this new legislation and taking steps to implement it. See future issues of the OCRWM Bulletin.

\section{Science Applications International Corporation Selected as Contractor for Licensing Support System}

Science Applications International Corporation (SAIC) has been awarded a contract for $\$ 5.28$ million for the period Sept. 30, 1987, through March 29, 1990, in support of a Licensing Support System (LSS). DOE's primary goal in developing the LSS is to obtain a system that is capable of storing, searching, and retrieving, in full text, the records needed for geologic repository licensing.

The services to be performed by SAIC include:

- definition of LSS requirements (in coordination with Nuclear Regulatory Commission rulemaking [see OCRWM Bulletin, September and November, 1987] on the submission and management of records and documents related to the licensing of a geologic repository for the disposal of high-level radioactive waste);

- design of a system to meet those requirements;

- preparation of hardware, software, and telecommunications specifications;

- development of appropriate applications software and integration of acquired software with developed software;

- testing and implementation of the system and verification of initial operation;

- development of procedures and training materials and documentation of all systems and procedures; and

- assuring the satisfactory loading of up to 4 million pages of data into the operational system.

The design of the LSS to be developed under this contract does not preclude expansion of the system at a later date under separate contracting provisions to provide support to other activities under OCRWM, such as those conducted by the Office of Storage and Transportation Systems, the Office of Resource Management, or the Office of Policy and Outreach.

\section{New Publications and Documents}

Additional Information on Monitored Retrievable Storage, DOE/RW-0166, November 1987.

On March 31, 1987, DOE submitted to Congress a proposal for the construction of a facility for monitored retrievable storage (MRS). Since this proposal was submitted, a number of questions have been raised by the General Accounting Office, the State of Tennessee, and others concerning the need for an MRS facility and the feasibility of achieving comparable performance for the overall waste-management system without an MRS facility. This report was prepared to provide additional information to address these questions.

Long-Term Performance of High-Level Glass Waste Forms, NUREG/CR-4795, BMI-2143, November 1987.

This report prepared for the U.S. Nuclear Regulatory Commission summarizes the results of experimental, analytical, and modeling studies performed by the Battelle Columbus Division to evaluate the long-term performance of high-level waste glass.*

Long-Term Performance of Container Materials for High-Level Waste, NUREG/CR-4955, BMI-2155, November 1987.

This report prepared for the U.S. Nuclear Regulatory Commission by the Battelle Columbus Division describes the results of experimental and analytical studies of high-level waste container degradation. Corrosion and hydrogen embrittlement tests were conducted on selected materials to identify environmental and metallurgical factors that promote material degradation, especially stresscorrosion cracking. A major emphasis on overpack materials focused on cast and wrought low-carbon steels.*

* For copies of these reports, contact the National Technical Information Service, Springfield, VA 22161. 


\section{Amendment to From-Reactor Cask Development Strategy as Portrayed in the Office of Civilian Radioactive Waste Management Transportation Business Plan*}

\section{Background}

As described in the Transportation Business Plan (DOE/RW-0046), January 1986, OCRWM is conducting a sequentially-phased cask development program to meet the transportation requirements of the Nuclear Waste Policy Act of 1982 (NWPA). The development program is divided into four initiatives: from-reactor casks suitable for shipping either to a repository or monitored retrievable storage (MRS) facility; MRS to repository casks; casks for non-standard spent fuel and non-fuel components; and defense waste casks. Current activity is focused on the first initiative, the fromreactor cask. Initially, consideration was given to developing legal weight truck casks, overweight truck casks, rail and/or barge casks, and dual purpose (transportation and storage) casks. Several factors have led to an amendment to the original strategy for developing the fromreactor casks, as discussed below.

\section{Amendment}

At this juncture of implementing Initiative 1 (which is the project for development of prototype casks for the from-reactor cask fleet), OCRWM will develop only legal weight truck and rail/barge casks (100-ton). Development of overweight truck casks is deferred pending resolution of institutional issues associated with overweight operations. Active development of dual purpose cask designs will be deferred indefinitely. The opportunity for including dual purpose casks in future operations (as defined on page 20 of the Transportation Business Plan) remains unchanged.

\section{Discussion}

Initiative 1 has been implemented to this point in accordance with the Transportation Business Plan. That project is prepared to issue contracts to proceed with cask development. Because of the uncertainty in program needs, OCRWM has reassessed its original cask development strategy and has found that adjustments will be made to reflect current institutional and technical realities and to reduce current expenditures from the Nuclear Waste Fund.

The following long-held objectives of the Transportation Program do not change:

- All surface modes of transportation will be considered;

- Intermodal transportation will be used where appropriate;

- At least two designs for each cask category (now legal weight truck and rail/barge) must be developed;

- Transportation systems will maximize payload in order to minimize the number of shipments while meeting safety requirements;

- A diverse complement of cask design contractors will be qualified.

These objectives have been held consistently by the Transportation Program since the issuance of the precursor to the Business Plan, the Strategy Options Document (DOE/RW-0007), October 1984, and have been the subject of a long public review process.

Since the issuance of the Business Plan, a number of important events have oocurred:

- Additional program direction has been received with Congressional enactment of the Nuclear Waste Policy Amendments Act of 1987.

- An amendment to the Mission Plan for OCRWM (DOE/RW-0128), June 1987, has been issued which proposes deferring both the start-up of the first repository and the second repository and which proposes a monitored retrievable storage facility (MRS). A revision of the Mission Plan is currently being prepared.

- The Fiscal Year 1988 budget for the entire OCRWM program is about half of the original OCRWM planning base of $\$ 725$ million.

- Proposals received for the Initiative 1 solicitation were significantly above cost projections.
- An internal DOE Inspector General audit has made recommendations regarding the Transportation Program.

- Comments were requested of State, Tribal, industry and utility representatives at the Transportation Coordinating Group meeting in Denver on Oct. 7, 1987.

As a result of these events, OCRWM has decided that certain adjustments must be made even though the adjustments will reduce the system flexibility during system start-up, as originally defined in the Business Plan.

Overweight truck shipments in large numbers may prove to have significant associated administrative and institutional problems as is stated in a recent study performed for OCRWM. The resolution of issues created by extensive use of overweight truck shipments, such as uniform permitting, is being pursued by the Transportation Program. While progress is being made in resolving issues, it is slower than had been expected; therefore, it is still premature to suggest that overweight trucks are truly viable for fleet operation. Since there remains a very real possibility that, within a 2-3 year period, some of these issues may be sufficiently resolved to make a decision as to the appropriateness of exercising this option, reasonable efforts have to be made to retain the benefits of the fromreactor solicitation.

The use of the overweight truck option has not been foreclosed, but rather development and associated substantial cost commitments are deferred until more progress has been made in resolving the administrative and institutional issues. Also, the capacity increases for legal weight truck casks in some of the fromreactor cask proposals were much greater

* To be incorporated into the draft Transportation Plan which is scheduled to be issued in 1988.

(continued on page 5) 


\section{Amendment to From-Reactor Cask Development Strategy as Portrayed in the Office of Civilian Radioactive Waste Management Transportation Business Plan \\ (continued from page 4)}

than expected, making the legal weight truck casks potentially more competitive with overweight truck casks than was anticipated. Deferring the overweight truck cask development at this time potentially may cause some loss in flexibility since this type of cask can be efficiently used for intermodal shipments by rail while, generally speaking, legal weight trucks are less efficient. However, the advantages of providing an interim period for review of viability of this option far outweigh the potential flexibility which may be sacrificed temporarily.

The development of dual purpose casks by the Transportation Program was premised on the desirability of developing a full complement of casks in a range of weight categories that would be as efficient as possible for transport from the myriad of reactors of varying cask handling capability. It was further recognized that the dual purpose cask could be of immediate value to the utilities in meeting their near-term storage requirements. The desirability of having a very large cask, such as the 125-ton dual purpose cask, remains, but under present budgetary constraints, indications are that Nuclear Waste Fund expenditures would be more effectively allocated to a fewer number of designs in fewer weight categories. Though dual purpose casks are more efficient for transport from utilities that are able to handle them, a 100-ton rail/barge cask could serve the same utility for transport purposes. When faced with a choice between dual purpose casks and 100-ton rail/barge casks, the 100-ton rail/barge cask is the logical selection for a start-up fleet that would have to serve all reactors.

The choice becomes easier as other recently developed information becomes available. Total life cycle cost studies performed recently by OCRWM indicate that dual purpose casks may not be as competitive with other storage options, such as concrete module storage, as was assumed in the Business Plan. The cooperative programs under Section 218 of the NWPA also have proved very successful, and industry now appears quite able to proceed with storage-only and (possibly) dual purpose casks without involvement of the OCRWM Transportation Program. Furthermore, since the schedule for Initiative I has been extended by one year as a result of a delay in the procurement cycle, and with a 6-7 year development period, it is not clear that Federal development of these casks would provide significant benefit to the utilities by the early 1990 s.

These factors mandate at least a temporary deferral of active development of dual purpose cask designs by the OCRWM Transportation Program. Resolution of technical issues regarding certification and shipping of dual purpose casks will continue. The use of a utility supplied dual purpose cask is not foreclosed and the prescription for its viability to the utilities remains the same as described in the Business Plan.

By developing the legal weight truck and rail/barge casks, the core of the transportation fleet is still being produced. All reactors can still be serviced. Input to repository and MRS receiving and handling facility designs can still be provided on an equal basis for both truck and rail. Such design input is important since these surface facilities are particularly sensitive to cask capacities. Within the rail/barge and legal weight truck cask categories, at least two designs for each mode will continue to be developed. This strategy will increase the likelihood of at least one cask design being available for a start-up fleet in each weight category since there is a risk of failure to achieve a certificate of compliance for all packages. Therefore, the strategy will provide a backup capability for operations should an unforeseen cask certification problem arise. The multiple design efforts will also benefit from the resulting competition and mandatory exchange of design information.

This amendment to the from-reactor cask development strategy will satisfy the basic objectives of the Transportation Program. The development of high capacity legal weight truck casks and rail/barge casks will make it possible to transport spent fuel from all reactors with reasonable efficiency. The door is left open to permit overweight truck cask development at a later time if considered advantageous. Deferral of dual purpose cask development also appears to be prudent based on recent developments. These proposed changes will make it possible to meet the major goal of being ready to transport fuel when required for operation of a federal storage or disposal facility. They will also result in a significant reduction in transportation system development costs at this early stage of the program.

\section{Selected Events Calendar}

Jan. 28-29 Workshop on the Consultation Draft Site Characterization Plan for the Yucca Mountain, Nevada Site, Reno, Nevada. Contact Judy Leahy (202) 586-8320.

Feb. 28- "Waste Management '88", University of Tucson, Tucson, AZ.

March 3 Contact M. E. Wacks (602) 621-6160.

For details on DOE/NRC meetings call (1/800) 368-2235 for a recorded message. In the Washington, DC, area call 479-0487.

A telephone recording service has been established for the announcement of upcoming meetings related to the waste management program of the NRC. The number is (1/800) 368-5642; Ext. 79002. Washington, DC, area residents should call 427-9002.

For information on meetings and events occurring between issues of the OCRWM Bulletin use OCRWM INFOLINK, an electronic bulletin board that can be accessed through a standard computer communications capability on (202) 586-9359. The OCRWM Bulletin is now available through INFOLINK. it 


\section{OCRWM Bulletin}

United States Department of Energy Office of Civilian Radioactive Waste Management

Washington, DC 20585

February 1988

\section{Right-of-Way Reservation Granted to DOE at Yucca Mountain Site}

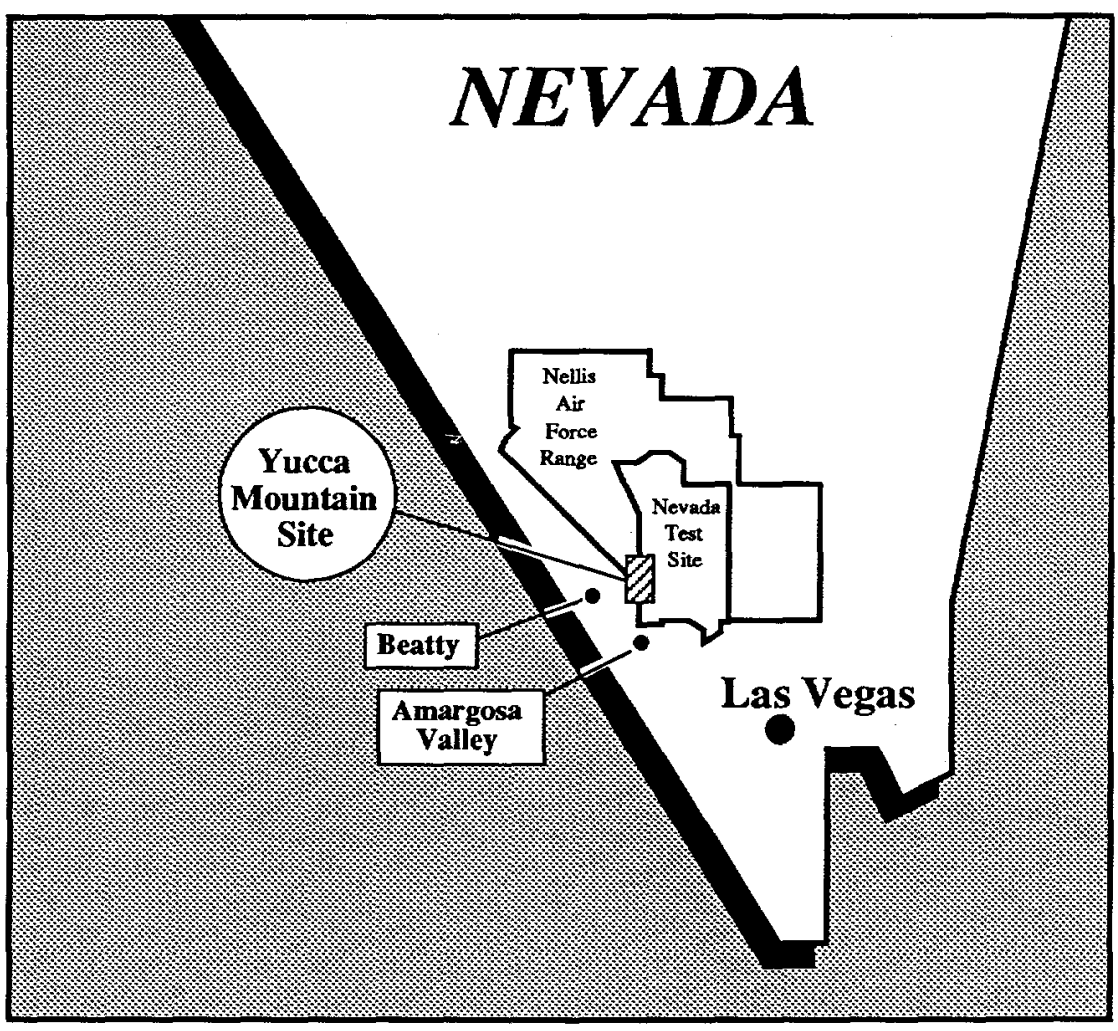

On Jan. 6, 1988, by grant of a right-of-way reservation (ROWR), the Bureau of Land Management (BLM) has authorized the use by DOE of public lands for site characterization activities in the vicinity of the Yucca Mountain site, Nevada. The lands covered by the ROWR include approximately 51,632 acres and are managed by the Department of Interior's BLM, with a portion of the lands located on the Nellis Air Force Range.

Through the Nuclear Waste Policy Amendments Act of 1987, Congress has directed DOE to characterize the Yucca Mountain site for development of the first repository. The ROWR focuses on Yucca Mountain and the range of site characterization activities that must be performed in order to technically establish the geologic and hydrologic conditions of the area. Six types of site characterization activities are planned: hydrologic, geologic, geophysical, geochemical, paleoclimatic, and meteorological. These activities include, but are not limited to, installation of environmental monitoring facilities; exploratory shaft construction and subsurface construction of research facilities; meteorological monitoring studies; installation of rain and stream flow gauges; and geologic mapping.

In granting this ROWR, the BLM retains the right to occupy and use the right-ofway or grant rights-of-way or other land uses for other purposes provided that the occupancy and use will not unreasonably interfere with the rights granted to DOE. After consultation with DOE, the BLM may authorize other uses within the "core area" where the exploratory shaft construction and other activities will take place. DOE will initiate consultation with BLM for proposed uses elsewhere within the ROWR area.

(continued on page 2)

\section{In This Issue}

Right-of-Way Reservation Granted to DOE at Yucca Mountian Site

OCRWM Grant and Project

Closeout Activities

Mission Plan Amendment to be

Developed by DOE

OCRWM Budget

Highlights of Actions Required in 1988 by the Nuclear Waste Policy

Amendments Act of 1987

Report Issued on Federal Interim Storage

Currently Scheduled OCRWM Short-Term Program Milestones

Selected Events Calendar

New Publications and Documents
Page

1

2

3

4

5

2

5

6

Published by the U.S. Department of Energy (DOE), Office of Civilian Radioactive Waste Management (OCRWM)

For further information about the national program or for copies of new publications and documents listed in the OCRWM Bulletin contact the U.S. Department of Energy, OCRWM, Office of External Relations and Policy, Mail Stop RW-40, 1000 Independence Avenue, SW, Washington, DC 20585, (202) 586-5722. The OCRWM Information Services Directory is available to provide sources of program information for the States, Indian Tribes, involved parties, and the public. 


\section{OCRWM Grant and Project Closeout Activities}

On Dec. 22, 1987, President Reagan signed into law the Nuclear Waste Policy Amendments Act of 1987 (Amendments Act). This legislation substantially changes the Nuclear Waste Policy Act of 1982 (NWPA) and the manner in which DOE conducts the radioactive waste disposal program.

\section{Grants Closeout}

Sections 5032 and 5033 of the Amendments Act provide for major changes to Sections 116 and 118 of the NWPA regarding provision of financial assistance to States and Indian Tribes. The amendment to Section 116 states: "No State, other than the State of Nevada, may receive financial assistance under this subsection after the date of the enactment of the Nuclear Waste Policy Amendments Act of 1987." As a result, no further financial assistance under the NWPA may be provided to the States of Louisiana, Mississippi, Texas, Utah, and Washington. The States have been directed to closeout all activities currently funded by grants under the NWPA. Any remaining grant funds can be used only for the purpose of engaging in an orderly close out of existing commitments. All remaining funds must be returned to
DOE in accordance with provisions outlined in 10 Code of Federal Regulations 600.123.

Section 5033 of the Amendments Act amends Section 118(b)(5) of the NWPA and provides that affected Indian Tribes may not receive any grants after Dec. 22, 1988.

\section{Project Closeout Activities}

Section 5011 of the Amendments Act directs the Secretary of Energy to provide for orderly phase-out of sitespecific activities, except in Nevada, (other than reclamation activities) within 90 days. Actions resulting from this Congressional direction include:

- the consultation drafts of the site characterization plans for the Hanford, WA, and Deaf Smith County, TX, sites will not be released;

- the meeting between DOE and the affected States and Indian Tribes, scheduled for Jan. 27, 1988, and the plenary session to initiate consultation on the draft site characterization plans scheduled for Jan. 28-29, 1988, were cancelled;
- the environmental monitoring and mitigation plans, the socioeconomic monitoring and mitigation plans, and the environmental regulatory compliance plans for the Hanford and Deaf Smith sites will not be released;

- the meetings of the Office of Geologic Repositories coordinating groups, scheduled to occur within 90 days of the passage of the Amendments Act will not be held. These include the Geosciences Coordinating Group, the Quality Assurance Coordinating Group, the Performance Assessment/ Safety Assessment Coordinating Group, the Environmental Coordinating Group, and the Institutional/ Socioeconomic Coordinating Group. However, the current plan is to hold the Transportation Coordinating Group Meeting as scheduled on March 29-30, 1988, in Atlanta, GA.

In addition to the above actions, planning that addresses such activities as site reclamation, closing of information offices, termination of contracts, disposition of equipment, and disposition of work-in-progress is underway at the Texas and Washington sites.

\section{Right-of-Way Reservation Granted to DOE at Yucca Mountain Site}

(continued from page 1)

It is not anticipated that site characterization activities will interfere with current or planned activities on the lands within the ROWR area. Archeological and threatened and endangered species surveys will be conducted by DOE prior to the start of surface disturbing activities. DOE will fulfill all requirements of the National Environmental Policy Act and all requirements of the Plan of Development that is included in the ROWR and further listed in Sections 4.1.1.4 and 4.1.2.6 of the Environmental Assessment for the Yucca Mountain site. Mitigation and reclamation will be used to return lands disturbed by site characterization to a stable ecological state with a form and productivity similar to the predisturbance state. Reclamation activities will occur in three phases: interim reclamation and site stabilization which will occur during site preparation and construction; final reclamation following abandonment or termination of sites; and post-reclamation monitoring.

The ROWR is for site characterization activities and does not convey any rights for the construction or initial operation of a nuclear waste repository.

\section{Currently Scheduled OCRWM Short-Term Program Milestones}

April 1988

Issue OCRWM Annual Report to Congress

Spring 1988 Issue draft Mission Plan Amendment

July 1988

Issue Annual Capacity Report 


\section{Office of Civilian Radioactive Waste Management Budget (Dollars in Thousands)}

\begin{tabular}{|c|c|c|c|}
\hline Activity & $\begin{array}{c}\text { FY } 1987 \\
\text { Actual }\end{array}$ & $\begin{array}{l}\text { FY } 1988 \\
\text { Estimate }\end{array}$ & $\begin{array}{l}\text { FY } 1989 \\
\text { Request c }\end{array}$ \\
\hline First Repository. & $\$ 296,881$ & $\$ 240,900$ & $\$ 289,661$ \\
\hline Second Repository . . . . . . . . . . & $19,800^{\text {a }}$ & 3,500 & 0 \\
\hline Monitored Retrievable Storage $\ldots \ldots \ldots \ldots$ & 20,000 & 4,000 & 15,000 \\
\hline $\begin{array}{l}\text { Transportation, Systems Integration } \\
\text { and Engineering Development } \ldots \ldots \ldots \ldots\end{array}$ & 25,500 & 37,000 & 43,600 \\
\hline $\begin{array}{l}\text { Program Management and } \\
\text { Technical Support } \ldots \ldots \ldots \ldots \ldots \ldots\end{array}$ & 45,871 & 56,800 & 62,232 \\
\hline Capital Equipment. . . . . . & 11,944 & 17,800 & 23,339 \\
\hline Construction $\ldots \ldots \ldots$ & $\begin{array}{c}0 \\
79,000^{b}\end{array}$ & 0 & 0 \\
\hline Total Program. . & $\$ 498,996$ & $\$ 360,000$ & $\$ 433,832$ \\
\hline
\end{tabular}

a/ Of this amount, $\$ 10,200,000$ was largely in support of nonsite specific investigations of the suitability of crystalline rock for repository medium. The remaining $\$ 9,600,000$ supported, to a great extent, the development of generic experimental techniques and analytical methods to be applied to repository geologic media taking advantage of applicable international experience.

b/ DOE reserve pending completion of the terms contained in the Continuing Resolution P.L. 99-500 and P.L. 99-591.

c/ Submitted to Congress on February 18, 1988. Details of budget request to appear in March OCRWM Bulletin.

\section{Mission Plan Amendment to be Developed by DOE}

When the original Mission Plan for the Civilian Radioactive Waste Management Program was issued in June 1985 to provide "an informational basis sufficient to permit informed decisions to be made in carrying out the programs required under the (Nuclear Waste Policy) Act" (NWPA), it was recognized that the information it contained would change over time requiring the document to be updated. In June 1987, following the procedures in Section 301 of the NWPA, the Mission Plan was amended to reflect the nomination and recommendation of sites for detailed site characterization, a 5-year extension of the schedule, a postponement of site-specific activities for a second repository, and other changes in OCRWM's priorities.

Since the June 1987 amendment to the Mission Plan, Congress has passed the Nuclear Waste Policy Amendments Act (Amendments Act) that has resulted in such significant changes in the OCRWM program (see OCRWM Bulletin for December
1987/January 1988), that the Mission Plan will be amended again. This action is needed in order to inform Congress and the public how DOE intends to implement the NWPA in view of the provisions of the Amendments Act and to summarize the current status of the Civilian Radioactive Waste Management Program. The process of developing a Mission Plan Amendment (MPA) is now underway.

While the details of the MPA are yet to be determined, the MPA is expected to cover such topics as:

- DOE's current plans for fulfilling its responsibilities under the Amendments Act. This will include a description of the authorized wastemanagement system, the development schedule for the wastemanagement system, an explanation of the waste-acceptance strategy for a system that consists of one repository and a Monitored Retrievable Storage facility, and contingency plans.
- An explanation of how the technical plans and activities for the program elements have been changed by the Amendments Act and what principal developments have occurred since the June 1985 Mission Plan and the June 1987 amendment.

- A description of institutional plans and activities including DOE's interactions with new organizations established by the Amendments Act, as well as with those, such as the State of Nevada, with which there has been an established relationship. Also included will be discussions of the transportation institutional program, consultation and cooperation, and financial assistance.

- A discussion of how the new program will be managed.

A draft of the MPA is scheduled to be completed in spring-1988 and will be available for review and comment. to 


\section{Highlights of Actions Required in 1988 by the Nuclear Waste Policy Amendments Act of 1987}

\begin{tabular}{|c|c|c|}
\hline Date & Action By & Action \\
\hline Enactment & $\begin{array}{l}\text { Secretary } \\
\text { Director, Office of } \\
\text { Research } \\
\text { President }\end{array}$ & $\begin{array}{l}\text { Terminate all second repository site-specific activities. } \\
\text { Offer to enter into benefits agreement with Nevada, } \\
\text { Offer to Nevada to designate representative to conduct on-site } \\
\text { oversight of site characterization activities. } \\
\text { Terminate grants to all states except Nevada. } \\
\text { Appoint Director of Office of Energy Subseabed Disposal Research. } \\
\text { Appoint Nuclear Waste Negotiator with advice and consent of } \\
\text { Senate. }\end{array}$ \\
\hline $1 / 21 / 88$ & $\begin{array}{l}\text { President Pro Tempore } \\
\text { of Senate } \\
\text { Speaker of the House }\end{array}$ & Appoint three members to MRS Commission. \\
\hline $2 / 20 / 88$ & Secretary & Establish university-based Subseabed Consortium. \\
\hline $3 / 21 / 88$ & $\begin{array}{l}\text { Secretary } \\
\text { National Academy of } \\
\text { Sciences (NAS) } \\
\text { President }\end{array}$ & $\begin{array}{l}\text { Terminate all site-specific activities at Texas and Washington sites } \\
\text { (except reclamation). } \\
\text { Recommend to President } 22 \text { persons to serve on Nuclear Waste } \\
\text { Technical Review Board (NWTRB). } \\
\text { Appoint } 11 \text { persons to NWTRB from among } 22 \text { recommended by } \\
\text { NAS. }\end{array}$ \\
\hline $4 / 20 / 88$ & $\begin{array}{l}\text { Nuclear Waste Technical } \\
\text { Review Board }\end{array}$ & Terms begin -5 members for 2 years, 6 members for 4 years. \\
\hline $6 / 22 / 88$ & Secretary & Conclude phaseout of crystalline rock research programs. \\
\hline $9 / 22 / 88$ & Secretary & $\begin{array}{l}\text { Report to Congress on analysis of institutional, cost, environmental } \\
\text { and other factors related to subseabed disposal with } \\
\text { recommendations. }\end{array}$ \\
\hline $10 / 1 / 88$ & Secretary & $\begin{array}{l}\text { Report to Congress on study and evaluation of dry cask storage at } \\
\text { reactor sites. }\end{array}$ \\
\hline $12 / 22 / 88$ & $\begin{array}{l}\text { Secretary } \\
\text { Secretary } \\
\text { Nuclear Waste Technical } \\
\text { Review Board }\end{array}$ & $\begin{array}{l}\text { Report to Congress on potential impacts on Nevada in } 14 \text { subject } \\
\text { areas resulting from locating repository in Nevada. } \\
\text { Terminate all grants to Indian Tribes related to states other than } \\
\text { Nevada. } \\
\text { Submit first report to Congress and annually thereafter. }\end{array}$ \\
\hline $12 / 31 / 88$ & $\begin{array}{l}\text { Director, Office of } \\
\text { Subseabed Disposal Research }\end{array}$ & Submit first annual report to Congress. \\
\hline
\end{tabular}




\section{Report Issued on Federal Interim Storage}

DOE has issued its fifth annual report to Congress on possible plans for providing limited Federal Interim Storage (FIS) capacity for U.S. commercial spent nuclear fuel.

The Nuclear Waste Policy Act (NWPA) charges DOE with developing a waste management system for the permanent disposal of spent nuclear fuel and high-level radioactive waste in a deep, geologic repository. Until DOE takes title to the spent fuel, the owners and operators of civilian nuclear power reactors have the primary responsibility for providing storage for their spent fuel.
DOE also has responsibility, under the NWPA, for providing not more than 1,900 metric tons of capacity for interim storage of spent fuel from civilian power reactors that cannot reasonably provide adequate storage capacity on-site. However, the Nuclear Regulatory Commission (NRC) must make a determination of the eligibility of an applicant for FIS under the criteria and procedures in Title 10, Code of Federal Regulations, Parts 1 and 53.

The objective of the current FIS program is to plan for a Federal capability to store, on an interim basis, this spent fuel if required. To date, the NRC has not received any applications from nuclear power plants for a determination of eligibility for FIS.

If it becomes necessary to implement deployment of FIS, the Federal Interim Storage Fund established by the NWPA will be used to provide full cost recovery to the government from FIS users. OCRWM has developed a plan to assure deployment capability when and if it is necessary, but it is premature to identify specific sites and plans at this time as no expressed need has arisen.

\section{Selected Events Calendar}

March 15

Mar. 22-24

Mar. 29-30

Apr. 18-19

May 18-19

June
Fiscal Year 1989 Budget Hearings, House Energy and Water Subcommittee of the House Appropriations Committee, Washington, DC.

High-Level Waste Licensing Support System Advisory Committee Meeting, Reno, NV.

Contact Howard Bellman, The Conservation Foundation, (202) 293-4800.

Transportation Coordinating Group Meeting, Waverly Hotel Atlanta, GA.

Contact Ellen Livingston-Behan, (202) 646-6676. For reservations contact the Waverly Hotel at (404) $953-4500$.

High-Level Waste Licensing Support System Advisory Committee Meeting, Washington, DC. Contact Howard Bellman, The Conservation Foundation, (202) 293-4800.

High-Level Waste Licensing Support System Advisory Committee Meeting, Washington, DC. Contact Howard Bellman, The Conservation Foundation, (202) 293-4800.

High-Level Waste Licensing Support System Advisory Committee Meeting (date to be determined), Reno, NV. Contact Howard Bellman, The Conservation Foundation, (202) 293-4800.

For details on DOE/NRC meetings call (1/800) 368-2235 for a recorded message. In the Washington, DC, area call $479-0487$.

A telephone recording service has been established for the announcement of upcoming meetings related to the waste management program of the NRC. The number is (1/800) 368-5642, Ext. 79002. Washington, DC, area residents should call 427-9002.

For information on meetings and events occurring between issues of the OCRWM Bulletin use OCRWM INFOLINK, an electronic bulletin board that can be accessed through a standard computer communications capability on (202) 586-9359. The OCRWM Bulletin is now available through INFOLINK. 


\section{New Publications and Documents}

Consultation Draft Site Characterization Plan, Overview, Yucca Mountain Site, Nevada Research and Development Area, DOE/RW-0161, Jamuary 1988.

This Overview consists of brief summaries of important topics covered in the consultation draft of the site characterization plan for the Yucca Mountain Site, Nevada. It contains brief descriptions of the disposal system, the site, the repository, and the waste package. In addition, it discusses the characterization program to be carried out at the Yucca Mountain site. It is intended primarily for the management staff of organizations involved in DOE's repository program who might wish to understand the general scope of the site characterization program, the activities to be conducted, and the facilities to be constructed rather than the technical details of site characterization.

OCRWM Backgrounder: Radiation and High-Level Radioactive Waste, DOE/RW-0167, February 1988.

This Backgrounder presents information about the sources, effects, and relative risks of ionizing radiation.

OCRWM Backgrounder: Geographic Distribution of High-Level Radioactive Waste, DOE/RW-0168, February 1988.

This Backgrounder provides a tabulation in terms of metric tons and cubic meters of existing and projected spent nuclear fuel by State in 1986 and 2000. It also provides a tabulation in cubic meters of existing and projected national inventories of high-level radioactive waste by source and State.

OCRWM Backgrounder: Health and Safety Protection in the Management of the Nation's High-Level Radioactive Waste, DOE/RW-0169, February 1988.

OCRWM separates the safety issues for geologic repositories into three major categories; systems safety, radiological safety, and industrial safety (OCRWM Safety Plan, DOE/RW-0119, December 1986). This Backgrounder discusses each of these categories and describes the policies, standards, and activities relevant to the pursuit of safety in OCRWM's management of spent nuclear fuel and high-level radioactive waste.

OCRWM Backgrounder: The Multiple Barrier System of Geologic Disposal of Spent Nuclear Fuel and High-Level Radioactive Waste, DOE/RW-0170, February 1988.

This Backgrounder describes the three elements that comprise the multiple barrier system, namely the waste package, the repository, and the host geologic medium. These elements are designed to complement each other in order to provide a high degree of nuclear waste containment and isolation.

Environmental Monitoring and Mitigation Plan for Site Characterization, Nevada Nuclear Waste Storage Investigations Project, Revision 1, DOE/RW-0176, January 1988.

This report describes the site-specific Environmental Monitoring and Mitigation Plan to be implemented during site characterization at the Yucca Mountain site to document compliance with Section 113(a) of the Nuclear Waste Policy Act.

Draft Environmental Regulatory Compliance Plan for Site Characterization of the Yucca Mountain Site, Nevada Nuclear Waste Storage Investigations Project, DOE/RW-0177, January 1988.

This document describes the plan by the Nevada Nuclear Waste Storage Investigations Project Office will comply with applicable environmental statutes and regulations. Also, it discusses how DOE will address State and local environmental statutes and regulations.

Socioeconomic Monitoring and Mitigation Plan for Site Characterization, Nevada Nuclear Waste Storage Investigations Project, Revision 1, DOE/RW-0179, January 1988.

This report describes the site-specific Socioeconomic Monitoring and Mitigation Plan to be implemented during site characterization at the Yucca Mountain site to document compliance with Section 113(a) of the Nuclear Waste Policy Act.

Implementation Plan for Deployment of Federal Interim Storage Facilities for Commercial Spent Nuclear Fuel, DOE/RW-0120, January 1987.

This is the fifth annual report to Congress on possible plans for providing limited Federal Interim Storage capacity for U.S. commercial spent fuel. 
United States Department of Energy Office of Civilian Radioactive Waste Management Washington, DC 20585

March/April 1988

\section{OCRWM Fiscal Year 1989 Budget Request}

\section{Budget Overview}

The FY 1989 budget proposed for OCRWM is based on the Nuclear Waste Policy Act of 1982 (NWPA) as amended by the Amendments Act of 1987 (Amendments Act; see OCRWM Bulletin December 1987/January 1988 for highlights). The budget request for FY 1989 from the Nuclear Waste Fund is $\$ 449$ million as compared to $\$ 360$ million in FY 1988 (Table 1). Since the NWPA requires the annual submission of a triennial budget under the Nuclear Waste Fund, in the discussion of the FY 1989 Nuclear Waste Fund program, estimates for FY 1990 and FY 1991 are included. The FY 1990 estimate is $\$ 624$ million and the FY 1991 estimate is $\$ 666$ million. For the years FY 1989 , FY 1990 , and FY 1991 the request and estimates are considerably lower than projected in previous years due to the new mandate to characterize only one repository candidate site instead of three and to terminate activities related to a second repository. For example, the FY 1988 budget request submitted to Congress last year estimated FY 1989 and FY 1990 as $\$ 1.10$ billion and $\$ 1.06$ billion, respectively. Therefore, in those two years the estimated savings are almost $\$ 1.1$ billion.

The FY 1989 budget request for the Civilian Radioactive Waste Research and Development program, as part of DOE's Energy Supply Research and Development programs, is $\$ 2.5$ million (see Table 2, page 2).

(continued on page 2)

\begin{tabular}{|l|r|r|r|}
\hline \multicolumn{4}{|c|}{ Table 1 } \\
FY 1989 Congressional Budget Request, Nuclear Waste Fund \\
(Dollars in Thousands)
\end{tabular}

In This Issue

OCRWM Fiscal Year 1989 Budget Request

OCRWM Organization Realigned Along Functional Lines

Status of Phaseout and Reclamation Activities

Meetings on the Yucca Mountain SCP/CD

Solicitation Closing Date

Extended for SEDM Contractor

Initial Version of Dry Cask

Storage Study to be Available for Comment

Currently Scheduled OCRWM Short-Term Program Milestones

Selected Events Calendar

New Publications and Documents

Published by the U.S. Department of Energy (DOE), Office of Civilian Radioactive Waste Management (OCRWM)

For further information about the national program or for copies of new publications and documents listed in the OCRWM Bulletin contact the U.S. Department of Energy, OCRWM, Office of External Relations and Policy, Mail Stop RW-40, 1000 Independence Avenue, SW, Washington, DC 20585, (202) 586-5722. The OCRWM Information Services Directory is available to provide sources of program information for the States, Indian Tribes, involved parties, and the public. 


\section{OCRWM Fiscal Year 1989 Budget Request}

(continued from page 1)

\section{Nuclear Waste Program}

The goal of the Nuclear Waste Fund program is to site, characterize, obtain licenses for, construct, and operate a waste management system, including a transportation system, for the disposal of spent nuclear fuel and high-level radioactive waste from commercial and atomic energy defense activities in a manner that is safe and environmentally acceptable. The mandate was established by the NWPA. While the goal remains unchanged, the site characterization program has been refocused because of the passage of the Amendments Act.
Table 2

FY 1989 Congressional Budget Request, Energy Supply Research and Development, Civilian Radioactive Waste Research and Development (Dollars in Thousands)

\begin{tabular}{|l|r|r|c|}
\hline & \multicolumn{2}{|c|}{$\begin{array}{c}\text { FY 1987 } \\
\text { Appropriation 1988 }\end{array}$} & $\begin{array}{c}\text { FY 1989 } \\
\text { Request }\end{array}$ \\
\hline $\begin{array}{l}\text { Spent Fuel Storage Development } \\
\text { Program Direction }\end{array}$ & $\begin{array}{r}\$ 6,287 \\
200\end{array}$ & $\begin{array}{r}\$ 4,800 \\
200\end{array}$ & $\begin{array}{r}\$ 2,300 \\
198\end{array}$ \\
Total Civilian R\&D & $-\$ 6,487$ & $\$ 5,000$ & $\$ 2,498$ \\
\hline Staffing & 3 & 3 & 3 \\
\hline
\end{tabular}

\section{First Repository}

Under the Amendments Act, DOE is directed to characterize only one site - the Yucca Mountain site in Nevada-to determine its suitability for the first repository and to terminate site-specific activities at the Hanford site in Washington and the Deaf Smith County site in Texas.

\begin{tabular}{|l|c|c|}
\hline \multicolumn{2}{|c|}{ Table 3 } \\
\multicolumn{2}{|c|}{ Schedule for the First Repository } \\
(In Calendar Years)
\end{tabular}

The FY 1989 request for activities associated with the first repository (including capital equipment) is $\$ 301$ million as compared to $\$ 256$ million for FY 1988. The estimate for FY 1990 is $\$ 405$ million and for FY 1991 is $\$ 435$ million. The increase in FY 1989 is needed to begin carrying out full site characterization including the issuance of the site characterization plan; to initiate construction of the first of two exploratory shafts; to complete pre-advanced conceptual design engineering studies for systems integration, waste package, and repository activities; and to provide financial assistance to the State of Nevada and affected units of local governments in Nevada.

The current schedule for major milestones associated with work at the Yucca Mountain site is essentially the same as that presented in the June 1987 OCRWM Mission Plan Amendment, with two exceptions: the start of exploratory shaft construction and the start of in-situ testing. Table 3 shows the current schedule.

(continued on page 3) 


\section{OCRWM Fiscal Year 1989 Budget Request}

(continued from page 2)

\section{Current and Planned First Repository Activities}

\section{Issuance of Site Characterization Plan for Nevada}

The Site Characterization Plan (SCP), which describes testing and analysis to be conducted at the Yucca Mountain site, was issued as a Consultation Draft to the State of Nevada and the Nuclear Regulatory Commission (NRC) on Jan. 8, 1988. The first general session, intended to begin the process of technical workshops with Nevada and the NRC, was held Jan. 28-29, 1988, in Reno, NV (for details of this meeting, see article on page 5). Also, associated environmental and socioeconomic plans were issued prior to Jan. 8. OCRWM plans to finalize the SCP so that it can be issued for public hearings and review and comment followed by initiation of exploratory shaft construction in June 1989.

The NRC has requested technical meetings on a number of SCP subjects. These meetings are being scheduled and the State of Nevada is invited to participate. As with other DOE and NRC technical meetings, these meetings are open to the public.

\section{Surface-based Testing}

During FY 1989, geologic, tectonic/ seismologic, hydrologic, and geochemical investigations will continue at the Yucca Mountain site as full site characterization proceeds. These investigations will complement initiation of exploratory shaft construction. Borehole and core sample drilling and testing will be increased, as well as envi- ronmental and socioeconomic characterization.

\section{International Programs}

An evaluation is currently being done of all ongoing international research programs to determine what continuation is appropriate. Following that evaluation, steps will be taken to phaseout funding for those research programs whose program objectives are not consistent with the Amendments Act.

It is important to the U.S. program to continue active participation in international cooperative activities in the area of radioactive waste management, such as those conducted under bilateral agreements and through participation in forums provided by such international organizations as the International Atomic Energy Agency and the Nuclear Energy Agency of the Organization for Economic Cooperation and Development.

In addition, DOE and the NRC, in accordance with Section 223 of the Nuclear Waste Policy Act, have jointly offered to cooperate and provide technical assistance to nonnuclear weapon states in a variety of areas related to radioactive waste management. This cooperation is continuing.

\section{Supporting First Repository Activities}

During FY 1989, engineering activities will include continuing the review and updating of the technical data base; systems engineering analysis and performance assessment to support preparation for the advanced conceptual design engineering work; continuing waste forms and materials and waste package environment testing and modeling; updating the rock mechanics data base; and international activities, as appropriate, in support of the first repository program.

Efforts will continue to implement the Environmental Monitoring and Mitigation Plan and monitoring data reports will be compiled. In addition, during FY 1989, environmental impact statement (EIS) scoping hearings may be held and an EIS implementation plan may be prepared.

Financial assistance to State and affected units of local governments for oversight will continue as required by Section 175 of the Amendments Act. DOE will submit a report to Congress on the potential impact of locating a repository at Yucca Mountain. In addition, DOE has offered to negotiate a Benefits Agreement with the State of Nevada. If an agreement is reached, benefits would then start.

\section{Phaseout and Reclamation}

For details in phaseout and reclamation activities see article on page 9 .

\section{Second Repository}

In accordance with the Amendments Act, the second repository program was terminated and closeout activities have been initiated. No funding for second repository activities is requested in $\mathrm{FY}$ 1989, FY 1990, or FY 1991.

(continued on page 4) 


\section{OCRWM Fiscal Year 1989 Budget Request}

(continued from page 3)

\section{Monitored Retrievable Storage (MRS)}

The Amendments Act authorizes an MRS facility as an integral part of the overall waste management system and places certain conditions on the timing of its siting and construction. The FY 1989 request for activities associated with the MRS program is $\$ 15$ million compared to $\$ 4$ million in FY 1988. The increase is primarily to initiate testing and demonstration of storage modules and packaging and handling equipment; to conduct design studies; and to begin a survey and evaluation of potential MRS sites. The estimate for FY 1990 is \$44 million and for FY 1991 is $\$ 53$ million.

This funding level for FY 1989 will provide for updating the analysis of the MRS facility need and role, conducting design tradeoff studies, and the development of facility design requirements and specifications. Design studies will be conducted to optimize system design and operations, to specify interfaces with the overall waste system, and to support the start of definitive facility design. Following submission of the MRS Review Commission report in June 1989, as called for in the Amendments Act, siting activities, including a survey and evaluation of potentially suitable sites, will be initiated.

Detailed planning for regulatory compliance will continue and work with national organizations to finalize plans for future interactions will proceed. Consistent with the Amendments Act, this funding level will permit DOE to provide and administer grants to interested States, Indian Tribes, or units of local governments to assess the feasibility of siting an MRS facility in their jurisdictions.

\section{Transportation and Systems Integration}

The FY 1989 request for transportation and systems integration activities is $\$ 44$ million compared to $\$ 37$ million in FY 1988. The estimate for FY 1990 is $\$ 74$ million and for FY 1991 is $\$ 81$ million.

\section{Transportation}

In FY 1989, work will continue on preliminary design of the from-reactor casks. Fabrication of scale models and verification testing will be initiated. Activities to resolve cask-certification technical issues will continue. In order to support the cask development program, DOE will continue to develop a cask components data base, materials data base, and automated cask handling technology. Development of functions and requirements for facilities needed to operate the transportation system will continue. Cooperative agreements with State and Tribal organizations, meetings, workshops, institutional planning, and issue resolution specific to a Nevada repository will continue at a level comparable to that in FY 1988.

\section{Systems Integration}

In FY 1989, a major portion of the reactor interface assessment project will be completed. In addition, as required by the Amendments Act, DOE is currently conducting a study and evaluation of the use of dry cask storage technology at reactor sites for temporary storage of spent fuel until such time as a permanent repository is constructed and licensed to operate. A report to Congress is due to be submitted by Oct. 1, 1988 (see article on page 8 ).

\section{Program Management and Technical Support}

For program management and technical support, the FY 1989 request is $\$ 74$ million compared to $\$ 60$ million in FY 1988 (including capital equipment). The increase is primarily to provide for program technical support and integration efforts. The estimate for FY 1990 is $\$ 86$ million and for FY 1991 is $\$ 82$ million.

As a major continuing initiative, $\mathrm{DOE}$ is in the process of developing an automated information storage and retrieval system known as the Licensing Support System (LSS) that will assist DOE in the licensing of a repository for the disposal of spent nuclear fuel and high-level radioactive waste. Access to the LSS will be available to interested parties prior to consideration of DOE's license application by the NRC.

Technical support includes continuing the reference data base on waste inventories and characteristics, and DOE will continue to participate in the waste acceptance issue resolution process involving utility representatives and other program elements. Also included in technical support are financial audit activities, annual fee verification and calculation studies, fund management activities, records management, and litigation support. In FY 1989, DOE will continue activities for the outreach program, including information reviews; continue international cooperation and participation in activities applicable and beneficial to OCRWM, and review foreign waste policy activities and development of procedures; and continue cooperative activities with national organizations.

(continued on page 5) 


\section{OCRWM Fiscal Year 1989 Budget Request}

(continued from page 4)

\section{Nuclear Regulatory Commission Fees}

DOE is currently conducting negotiations with the NRC to establish a Memorandum of Understanding to provide for payment from the Nuclear Waste Fund to the NRC for licensing-related activities. Based on an estimate of the level of activities and funding that may result from these negotiations, DOE is requesting $\$ 15$ million in FY 1989. The estimate for both FY 1990 and for FY 1991 is also $\$ 15$ million.

\section{Nuclear Waste Fund}

The Nuclear Waste Fund, established by the NWPA to collect fees from the generators and owners of spent nuclear fuel and high-level radioactive waste, is reviewed each year to assess the adequacy of the 1 mill per kilowatt hour fee established by the law. Based on the refocusing of the program, DOE is currently conducting its annual total system life-cycle costs analysis and assessing the adequacy of the current fee. Commercial utilities have been paying into the Fund since April 1983. Table 4 provides a status of the Fund.

\section{Table 4}

Nuclear Waste Fund Status, Cumulative through Jan. 31, 1988 (Dollars in Millions)

\section{RECEIPTS}

Fees

One-Time................. \$1,442.0

On-going (1 mill) .......... 1,773.2

Total Fees................... 3,215.2

Interest....................... $\quad 474.3$

Total Receipts............... 3,689.5

DISBURSEMENTS ........... $-1,721.9$

BALANCE .................... \$1,967.6

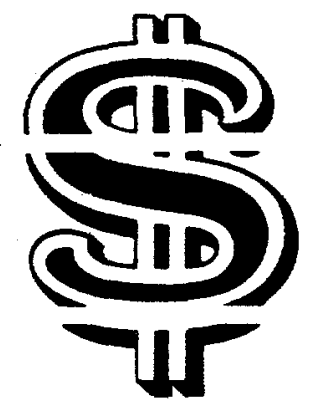

\section{Civilian Radioactive Waste R\&D}

The goal of the Civilian Radioactive Waste $R \& D$ program is to encourage and expedite the development and demonstration of technologies for the addition of new, temporary, onsite storage capacity for spent nuclear fuel to permit the orderly continuation of electricity generation operations by the utilities. The FY 1989 request is $\$ 2.5$ million compared to $\$ 5$ million in FY 1988. This decrease is due to the completion of participation in various cooperative agreements associated with spent fuel storage development.

In FY 1989, cooperative demonstrations will be completed with Virginia Power involving dry storage and rod consolidation, Carolina Power and Light involving concrete horizontal cask dry storage, and Northeast Utilities Services Company involving rod consolidation. In addition to issuing several reports on special studies, an annual update will be issued on the "Spent Fuel Requirements Report."

\section{Meetings on the Yucca Mountain Site Characterization Plan Consultation Draft}

On Jan. 8, 1988, DOE issued its Site Characterization Plan/Consultation Draft (SCP/CD) for the Yucca Mountain site in Nevada to serve as a vehicle for technical discussions with the State of Nevada and the NRC. To start these discussions a meeting was held in Reno, NV, on Jan. 28-29, 1988, to provide background information on the SCP/CD and environmental and socioeconomic documents to the technical experts of the State of Nevada, the NRC, other interested parties, and members of the general public who wished to attend the meeting.

Among the topics included in the agenda were the:

- SCP/CD and the consultation process;

- Background, organization, and preparation of SCPs;

- Issues hierarchy and issue resolution strategy;

- Yucca Mountain site top-level strategy;

- Implementation of the issue resolution strategy for the Yucca Mountain site; and

- Yucca Mountain site characterization program.

The meeting began with a presentation from representatives of Citizens Alert who requested greater efforts to publicize such meetings well in advance. A representative of the Nevada Nuclear Waste Study Committee supported the consultation process and encouraged the public to participate in the workshops. After the introductory remarks by Carl Gertz (Project Manager, Nevada Waste Management Project Office) and Stephen Kale (Associate Director, Office of Geologic Repositories), a (continued on page 6) 


\section{Meetings on the Yucca Mountain Site Characterization Plan Consultation Draft}

(continued from page 5)

statement of Nevada's concerns was given by Robert Loux, Executive Director, State of Nevada Nuclear Waste Project Office. A series of presentations followed which were given to provide an overview of the SCP/CD. In addition, environmental and socioeconomic documents associated with site characterization were discussed.

DOE proposed a series of workshops to explain complex aspects of the plans. The State of Nevada and the NRC were encouraged to raise technical concerns about the SCP/CD during the workshops. The objective of DOE is to develop an SCP that reflects these early consultations, in order to get the best possible review of the document when it is released to the public in late 1988.

DOE provided a document request form, and numerous requests for information were made. When the SCP is scheduled to be released, public meetings will be held. These opportunities for interaction and comment will be publicized widely to encourage public interest and participation.

Subsequent to the meeting in Nevada, the NRC transmitted to DOE on Mar. 7, 1988, the results of its technical review of the SCP/CD. In its Draft Point Papers the NRC identified five principal technical concerns, which they have termed "objections", and recommended that DOE not start site characterization work until they are resolved. These address:

- Need to recognize the range of alternative conceptual models of the Yucca Mountain site that can be supported by the existing limited data base.

- Status of the Quality Assurance plans for site characterization activities (i.e., any site characterization data collected before QA programs are in place may not be usable in the licensing process).

- Need to include the conceptual design information on the proposed Exploratory Shaft Facility to allow evaluation of potential interference of proposed investigations with each other or interference of construction operations in the shafts and drifts with these investigations.

- Potentially adverse impacts that could result from the proposed locations of the exploratory shafts in areas that may be subject to erosion and flooding.

- Effect of shaft penetration into the Calico Hills formation 400 feet below the repository horizon that may have significant negative impacts on the waste isolation capability of the site.

These five objections pertain to difficult issues which have been discussed extensively in the past and for which DOE intends to seek resolution during completion of the SCP. A workshop was held on Mar. 21-24, 1988, in Washington, DC, to discuss the NRC Draft Point Papers. At this meeting, DOE and the support contractor staffs sought clarifications from the NRC staff. Highlights of the sessions follow:

- Alternative Conceptual Models-The NRC staff indicated the need for clarification in the SCP/CD for alternative conceptual models. OCRWM conducted a technical workshop in Las Vegas on Apr. 11-14, 1988, on alternative conceptual models of the ground water system at Yucca Mountain. The results of this workshop will be reported in the next issue of the Bulletin.

- Design and Rock Mechanics - The NRC staff indicated the need for a better integrated drilling program, expanded discussion of the seals program, and rationale for the extent of shaft sinking in the Calico Hills and its effect on long-term repository performance.

- Geology and Geophysics-The NRC staff emphasized the need for identification of alternative testing strategies where possible.

- Hydrology and Climatology - The NRC staff expressed concern that DOE's analytical approach for ground water travel may not identify the actual fastest pathway.

- Waste Package-There was discussion on substantially complete containment. The NRC staff suggested a more conservative approach.

- Geochemistry-DOE and the NRC were generally in agreement with the program.

- Quality Assurance-DOE and the NRC agreed that DOE would provide a QA qualified program before new activities are initiated.

DOE is pleased by the thoroughness of the NRC review - such a review is what was sought when the SCP was issued in Consultation Draft form. DOE intends to address and resolve the NRC comments as appropriate, during the consultation period, prior to the release of the statutory SCP. 


\section{OCRWM Organization Realigned Along Functional Lines}

OCRWM has been reorganized. The main feature of the reorganization is the establishment of four functional program offices and an Office of Quality Assurance to replace the former project-oriented structure. The realignment, which applies only to DOE's headquarter's organization, places increased emphasis on quality assurance, facility licensing, systems integration, and external interactions.

Charles E. (Ed) Kay, Deputy Director of OCRWM, remains as Acting Director of OCRWM, a position he has held since the program's first permanent Director left DOE last November.

A new, separate Office of Quality Assurance will report to the Director of OCRWM. The purpose of this office is to assure development and implementation of an effective quality assurance program to demonstrate the technical performance of the waste management system. This is essential to obtain the required licenses from the NRC and establish the public confidence in the technical quality of the program.

Pierre Saget, detailed from DOE's Richland Operations Office, is currently Acting Director until a permanent Director is named. Sharing in the responsibility of establishing this function is William Kehew, on detail from DOE's Chicago Operations Office.

The four functional offices will each be headed by an Associate Director and a Deputy Associate Director.

The Office of Program Administration and Resource Management is responsible for administrative management and support services; cost and scheduling activities; budget preparation; grants and financial assistance programs; land acquisition; procurement activities, including the Management and Operating Contract for systems engineering, development and management support; and utility contracts. Samuel Rousso has been named as Associate Director and James C. Bresee as Deputy Associate Director.

The Office of Facilities Siting and Development is responsible for site characterization of the Yucca Mountain site in Nevada and the siting of an MRS facility. This Office is also responsible for the design and development of the repository; MRS facility and waste package; socioeconomic planning; consultation and cooperation; and benefits agreements. Stephen $\mathrm{H}$. Kale and Jerome D. Saltzman have been named as
Associate Director and Deputy Associate Director, respectively.

The Office of Systems Integration and Regulations is responsible for overall systems integration; facility licensing; regulatory and environmental compliance; transportation systems development and operation; risk, safety, and performance assessment; and spent fuel storage activities. Ralph Stein has been named as Associate Director and Keith A. Klein as Deputy Associate Director.

Thomas H. Isaacs has been named as Associate Director with Lake H. Barrett as Deputy Associate Director of the Office of External Relations and Policy. This Office is responsible for managing programs and interactions with the newly established MRS Review Commission and the Nuclear Waste Technical Review Board, as well as continuing external interactions with the State, local, and Tribal governments, the National Academy of Sciences, international organizations, the news media, the public, and Congress. In addition, this Office will coordinate development of program policy, strategy, and contingency planning.

A revised organization chart for OCRWM is shown below.

\section{OFFICE OF CIVILIAN RADIOACTIVE WASTE MANAGEMENT}

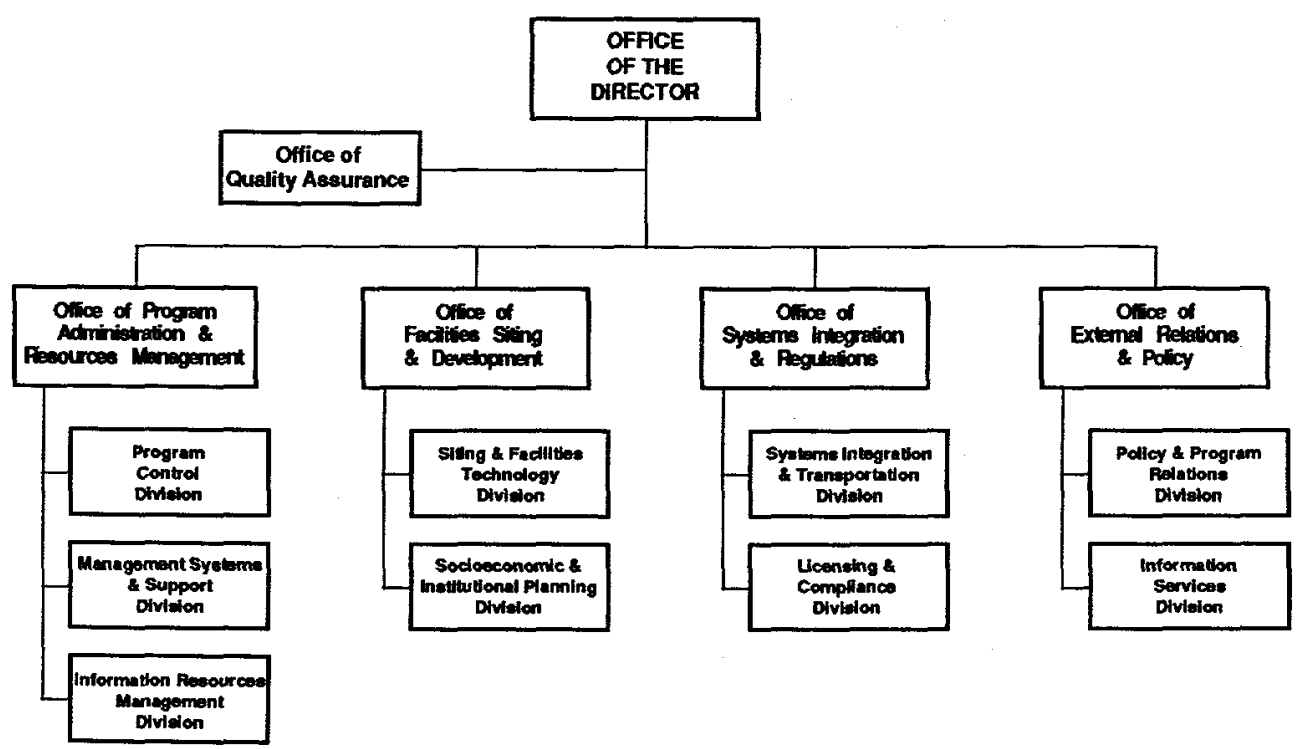




\section{Solicitation Closing Date Extended For SEDM Contractor}

On Oct. 5, 1987, a solicitation was issued for a Management and Operating Contractor for Systems Engineering, Development and Management (SEDM) of the Nuclear Waste Management System for the Ultimate Disposal of High-Level Radioactive Waste and Spent Fuel (see OCRWM Bulletins October and November 1987). Due to the passage of the Amendments Act on Dec. 22, 1987, and its refocusing of the program, the solicitation was revised and reissued on Feb. 25, 1988, and the closing date has been extended to Apr. 25, 1988.

The contractor will be responsible for design and analysis of the nuclear waste management system to ensure that the system is optimized and that the interfaces between the system elements are clearly specified and controlled, including transportation considerations. The contractor will be assigned specific responsibilities to ensure that the First Repository Candidate Site is characterized consistent with the NWPA as amended; and that, if found suitable, the selected site is engineered and developed through receipt of an NRC Construction Authorization. The contractor will provide the strategy options, leadership, and resources to assist DOE in obtaining the NRC licenses.

\section{Selected Events Calendar}

May 9-13 Title I Exploratory Shaft Facility Design Review, Contact Dean Stucker, OCRWM (202) 586-1238.

May 18-19 High-Level Waste Licensing Support System Advisory Committee Meeting, Washington, DC. Contact Howard Bellman, The Conservation Foundation, (202) 293-4800.

May 25-27 Close Out of Exploratory Shaft Facility Design Comments. Contact Dean Stucker, OCRWM, (202) 586-1238.

June 29-30 High-Level Waste Licensing Support System Advisory Committee Meeting, Reno, NV. Contact Howard Bellman, The Conservation Foundation, (202) 293-4800.

For details on DOE/NRC meetings call (1/800) 368-2235 for a recorded message. In the Washington, DC, area call 479-0487. A telephone recording service has been established for the announcement of upcoming meetings related to the waste management program of the NRC. The number is (1/800) 368-5642, Ext. 20436. Washington, DC, area residents should call 492-0436. For information on meetings and events occurring between issues of the OCRWM Bulletin use OCRWM INFOLINK, an electronic bulletin board that can be accessed through a standard computer communications capability on (202) 586-9359. The OCRWM Bulletin is now available through INFOLINK.

\section{Initial Version of Dry Cask Storage Study to be Available for Comment}

In accordance with Section 5064 of the Amendments Act, OCRWM is preparing a report on the use of dry cask storage (and other technologies currently being considered) at reactor sites. The study will assess the utility industry's spent nuclear fuel storage needs through the start of operation of the geologic repository scheduled for the year 2003 .

Preparation of this study and evaluation has been started by OCRWM, and the completed report will be submitted to Congress as required by the Amendments Act. The primary objectives of the study are to:

- Consider the costs of dry cask storage technology, the extent to which dry cask storage at reactor sites will affect human health and the environment, the extent to which the storage at reactor sites affects the costs and risks of transporting spent nuclear fuel to a central location such as an MRS facility, and any other appropriate factors.

- Consider the extent to which the Nuclear Waste Fund can be used, and should be used, to provide funds to construct, operate, maintain, and safeguard spent nuclear fuel in dry cask storage at reactor sites.

As part of this study, the views of State and local governments and the public will be solicited. To do this, an initial version of the report, scheduled for release this summer, will be made available on request to Gregory Hartkopf, OCRWM, U.S. Department of Energy, RW-32, Washington, DC 20585. A public comment period will take place after release. After reviewing comments received, DOE will determine if modifications to the report are warranted before it is submitted to Congress. In any case, comments received will be included in a comment appendix to the report.
店 


\section{Status of Phaseout and Reclamation Activities}

The Amendments Act calls for an orderly phaseout of site-specific activities at the basalt and salt sites and for termination of all site-specific activities (other than reclamation) at those sites by Mar. 21, 1988. To implement these provisions of the Amendments Act, OCRWM:

- Immediately notified all prime contractors, grantees, National Laboratories, and other Federal agencies of the Amendments Act requirements for termination of sitespecific activities and for an orderly phaseout. OCRWM also issued formal, technical guidance directing those parties to suspend or limit their activities;

- Concurrently, undertook a comprehensive review of all activities and developed plans for an orderly phaseout. The planning process was intended to ensure that site-specific activities would be terminated no later than Mar. 21, 1988, and that valuable information that might be needed for future uses would be preserved;

- Directed that detailed plans for reclamation be developed;

- Issued formal termination letters with specific directives to the majority of prime contractors and took the actions necessary to ensure near-term completion of open contracts.

After Mar. 21, 1988, the remaining managerial and administrative tasks include the following:

- Compilation, review, editing, indexing, and/or publication of key project documents, including computer programs;
- Final cataloging, classification, and disposition of surplus property;

- Closing of information and other offices in Louisiana, Mississippi, Utah, Washington State, and Texas;

- Employee outplacement and management and administration of grants and terminated contracts.

Reclamation activites at the basalt and salt sites include reclaiming the Near Surface Test Facility, the exploratory shaft, the Waste Pond, and the borehole sites in Utah, Louisiana, Mississippi, and Washington State. In addition, DOE will remove the seismic and erosion monitoring network and weather monitoring stations in Texas.

\section{New Publications and Documents}

\section{Quarterly Report on Program Cost and Schedule, First Quarter FY 1988, DOE/RW-0188, 1988.}

This report is intended to provide a summary of the cost and schedule performance for the civilian radioactive waste program. Performance data are presented for each of the major program elements. Also included in this report is the status of the Nuclear Waste Fund revenues and disbursements. This report includes performance data through December 1987.

\section{Peer Review for High-Level Waste Repositories, NUREG-1297*, Nuclear Regulatory Commission, Office of Nuclear Material Safety} and Safeguards

This document provides guidance on areas where a peer review is appropriate, the acceptability of the peers, and the conduct and documentation of a peer review in the high-level nuclear waste repository program.

Qualification of Existing Data for High-Level Nuclear Waste Repositories, NUREG-1298*, Nuclear Regulatory Commission, Office of Nuclear Material Safety and Safeguards

Subpart $\mathrm{G}$ of 10 Code of Federal Regulations 60 specifies a quality assurance program for items and activities important to safety and waste isolation. This document provides guidance on the use and qualification of data that have not been initially collected under a 10 CFR 60, Subpart G quality assurance program.

* For copies of these reports contact the National Technical Information Service, Springfield, VA 22161.

\section{Correction}

On page 4 of the February 1988 issue of the OCRWM Bulletin please note the following corrections:

- It is the Director, Office of Energy Research, who appoints the Director of the Office of Subseabed Research.

- By Jan. 21, 1988, the President. Pro Tempore of the Senate and the Speaker of the House are to appoint three members to the Monitored Retrievable Storage Review Commission.

- The reports of the Nuclear Waste Technical Review Board are to be issued semi-annually.

\section{Currently Scheduled OCRWM Short-Term Program Milestones}

May $1988 \quad$ Issue OCRWM Annual Report to Congress

May $1988 \quad$ Issue draft Mission Plan Amendment

July 1988 Issue Annual Capacity Report 
DO $\mathrm{NOT}$

THIS PAS

$88: 22$ 


\section{OCRWM Bulletin}

United States Department of Energy Office of Civilian Radioactive Waste Management Washington, $D C 20585$

\section{Excerpts from Recent Testimony by Charles E. Kay, Acting Director, OCRWM}

During May 1988, Acting Director Charles E. (Ed) Kay made presentations about the OCRWM program to the Subcommittee on Energy and the Environment of the Committee on Interior and Insular Affairs of the House of Representatives and to the Nuclear Regulatory Commission (NRC). Excerpts from these presentations follow:

\section{Testimony Before Congress}

(The purpose of this testimony, delivered on May 12, 1988, was to review transportation activities now being planned and conducted as part of the development of an integrated system for disposing of spent fuel and high-level radioactive waste. Before turning to a discussion of specific transportation issues and initiatives, the effect of recent legislation on the waste-management program as a whole was summarized as well as federal regulatory considerations that affect the transportation program. The remainder of the testimony was devoted to discussion of the four major elements of the transportation program: institutional interactions; cask design, development and testing; support systems development; and planning for transportation operations.)

\section{Institutional Interactions}

"DOE formally initiated a strong program of institutional interactions to complement all our transportation activities with publication of the Transportation Institutional Plan (DOE/RW-0094) in August 1986. As described in the plan, we are seeking and encouraging public participation in program planning by sponsoring and participating in a wide range of meetings and workshops, with special emphasis placed on the meeting of the Transportation Coordination Group (see article on page 3.) We are also continuing to develop a wide range of public information materials on program activities. Information products expected to be released in 1988 include detailed discussion papers on major transportation issues and the first iteration of a "comprehensive transportation plan" that reviews procedures and activities related to institutional, business and operational elements of the transportation program.

"To assist in the study of issues of special interest to States and Indian Tribes and to promote the cooperative development of plans and procedures, we have also initiated contractual arrangements with national, regional and transportation related organizations...In working with these and other groups, our attention most recently has focused on specific concerns as affected by the Amendments Act...

"Routing...Routing decisions will be central to transportation operations and, in addition, to schedules and plans for such activities as training, shipment inspections and emergency response ....aspects associated with routing that must be addressed in program planning include:

- The extent to which DOE will assist States and Indian Tribes in evaluating and designating highway routes as alternatives to Interstate System highways, in accordance with (Department of Transportation) DOT routing regulations;

(continued on page 4)

\section{In This Issue}

\section{Page}

Excerpts from Recent Testimony by Charles E. Kay, Acting Director, OCRWM

DOE Offers Onsite

Representation at Yucca

Mountain and Offers to

Negotiate Benefits Agreement

with Nevada

Clark County, Nevada, Designated as "Affected Unit

of Local Government"

Report on Transportation Coordinating Group Meeting

Nuclear Regulatory Commission Establishes Advisory Committee on Nuclear Waste

Currently Scheduled OCRWM Short-Term Program Milestones

Selected Events Calendar

Published by the U.S. Department of Energy (DOE), Office of Civilian Radioactive Waste Management (OCRWM)

For further information about the national program or for copies of new publications and documents listed in the OCAWM Bulletin contact the U.S. Department of Energy. OCRWM, Office of External Relations and Policy, Mail Stop RW-40, 1000 independence Avenue, SW, Washington, DC 20585, (202) 586-5722. The OCRWM Information Services Directory is available to provide sources of program information for the States, Indian Tribes, involved parties, and the public. 


\section{DOE Otfers Onsite Representation at Yucca Mountain and Offers to Negotiate Benefits Agreement With Nevada}

On Apr. 6, 1988, Secretary of Energy John S. Herrington wrote to Nevada Governor Richard $\mathrm{H}$. Bryan to offer to work with the State of Nevada to take advantage of new opportunities for consultation on nuclear waste activities that were provided by the Amendments Act.

Secretary Herrington informed Governor Bryan that, pursuant to section 5031 of the Amendments Act, DOE is prepared to enter into negotiations with the State on the development of the Benefits Agreement outlined in that section. Among other benefits, such an agreement would provide for State and local representation on a Review Panel with broad review and advisory responsibilities. It would also include a schedule of annual payments to the State.
Under section 5011 of the Amendments Act, Nevada has the opportunity to designate a representative to conduct oversight activities on site at Yucca Mountain. A similar position was offered by DOE in the past. An onsite representative would enhance the exchange of information and State participation benefiting both the State and DOE.

In this letter, DOE renewed its offer of Nov. 19, 1986, to enter into negotiations with Nevada for a Consultation and Cooperation Agreement under section 117 of the Nuclear Waste Policy Act. On May 20, 1988, Governor Bryan advised Secretary Herrington that the State of Nevada would not accept the DOE offers.

\section{Clark County Designated an "Affected Unit of Local Government"}

While the Clark County Commissioners remained opposed to site characterization of the Yucca Mountain site in Nevada as the only candidate site at this time for a permanent geologic repository, on Apr. 11, 1988, Clark County asked Secretary of Energy John S. Herrington, that it be designated as an "affected unit of local government" under the authority of Section 5002 of the Amendments Act. The Yucca Mountain candidate site is located in Nye County which is contiguous with Clark County. Clark County is the most populous county in Nevada and a major transportation, commercial and administrative center. It is also home to DOE's Nevada Operations Office which supervises programs taking place at the Nevada Test Site and Yucca Mountain.

DOE, in response, noted on Apr. 21 that "it is vital that local governments which may be affected by the program actively participate in its development" of a safe and environmentally acceptable repository site for radioactive waste. Accordingly, under the authority of the Amendments Act, Clark County has been designated as an affected unit of local government. This designation makes Clark County eligible to receive participation grants and impact mitigation assistance.

\section{Currently Scheduled OCRWM Short-Term Program Milestones}

July 1988

Sept. 1988

Oct. 1988

(
Evaluation to Congress to Congress

\section{Issue Annual Capacity Report}

Issue Fee Adequacy

Issue Report on Dry Cask Storage

\section{Nuclear Regulatory Commission Establishes Advisory Committee on Nuclear Waste}

In a Federal Register Notice published on Apr. 26, 1988, the NRC announced the establishment of the Advisory Committee on Nuclear Waste. The NRC has determined that the establishment of this committee is necessary and in the public interest in order to obtain expert advice and recommendations on all aspects of the management of radioactive wastes within the purview of NRC's regulatory responsibilities.

The purpose of the Committee is to provide advice and recommendations on topics, issues and activities related to the regulation of nuclear wastes. Such activities encompass:

- Regulation of high-level waste, including the licensing of highlevel waste repositories;

- Licensing and regulation of lowlevel waste disposal repositories; and

- Handling, processing, transporting, storing and safeguarding wastes, including but not limited to spent fuel, nuclear wastes mixed with other hazardous substances and uranium mill tailings. 


\section{Report on Transportation Coordination Group Meeting}

The Transportation Coordination Group (TCG) met in Atlanta, GA, on Mar. 29-30, 1988. Attending the meeting were representatives of OCRWM, States, Indian Tribes, utilities and the transportation industry. Highlights of the meeting follow:

\section{DOE Transportation Reports}

\section{- Cask Design and Development}

The Idaho Operations Office, which provides support for cask design and development activities, noted continued progress in contract negotiations for the development of "from-reactor" casks. Under current planning, two legal-weight truck casks and three rail-and-barge casks will be designed, all having capacities significantly greater than casks that are currently in use. Contracts will cover the design and development of casks, the development of test models, certification of cask designs by the NRC and the delivery of up to two prototype casks. At the time of the TCG meeting, one contract had been signed with General Atomics for the development of a legalweight truck cask. On Apr. 1, 1988 , a contract for the design of a rail-and-barge cask was completed with the Nuclear Assurance Cotporation.

\section{- Support System and Operations} Planning

Alternative approaches for providing the support facilities, equipment and services needed for an operating transportation system are being evaluated at the Oak Ridge Operations Office. Specifications for a cask maintenance facility will be developed during cask design. The development of other support facilities, such as a control center for operations, will proceed as functional requirements of an operational transportation system are defined.

\section{Systems Studies and Institutional Activities}

Progress reported by the Chicago Operations Office included development of a transportation system study plan and continued support of institutional activities with States and Indian Tribes and technical organizations. The Chicago Operations Office is also supporting preliminary planning for an OCRWM emergency preparedness workshop to discuss existing emergency preparedness programs and activities, review requirements for training assistance under the Amendments Act and identify information needs related to planning, training and emergency response. A list of proposed discussion items for the workshop agenda was distributed at the TCG meeting and comments were requested.

\section{Reports on Cooperative Agreement Activities}

Reports on activities conducted under cooperative agreements with OCRWM were provided by representatives of the following organizations:

\section{- Southern States Energy Board(SSEB)}

The SSEB has begun work on a "Transportation Report." Other nearterm activities include the development of a list of State routing authorities and a summary of emergency response capabilities and mutual aid agreements in the region.

- Western Interstate Energy Board (WIEB)

Activities include a survey of mutual aid agreements in the region, the development of issue papers on quality assurance and rail transport issues and a review of the NRC's "modal study."

\section{- National Congress of} American Indians (NCAI)

NCAI is focusing its activities on information dissemination (with issuance of a high-level waste newsletter), identification of Tribal contacts and the identification of Indian Tribal reservations and lands that may be affected by future transportation activities.

\section{- National Conference of State Legislatures (NCSL)}

Major work of the NCSL relates to the development of legislative updates and fact sheets on such topics as hazardous materials regulations and training.

\section{Selected Events Calendar}

June 29-30 High-Level Waste Licensing Support System Advisory Committee Meeting, Reno, NV. Contact Howard Bellman, The Conservation Foundation, (202) 293-4800.

For details on DOE/NRC metings call (1/800) 368-2235 for a recorded meskage. In the Washington, DC, ares call 479-0487,

A telephone recording service bas boen extablished for the announcement of upcoming meetings related to the waste manngement program of the NRC. The number is (1/800) 368-5642, Ext. 20436. Washington, DC, area residents sbould call 492-0436.

For information on moetings and events occurring between issues of the OCRWM Bulletin use OCRWM INFOLINK, an electronic bulletin boand that can be uccessed through a standerd compater commmications capability on (202) 586-9359. The OCRWM Bwletin is now available through INFOLINK. 


\section{Excerpts from Recent Testimony by Charles E. Kay, Acting Director, OCRWM}

(continued from page 1)

\begin{abstract}
The process by which representative routes should be identified for transportation analyses conducted in support of the environmental studies of potential repository and Monitored Retrievable Storage Facility (MRS) sites; and
\end{abstract}

- The procedures that will be used to select routes for actual shipping to waste disposal and storage facilities.

"...Under the direction of DOE headquarters, Oak Ridge National Laboratory has developed a number of computerized transportation programs and data bases which contain essentially a computerized atlas of highways, rail lines or navigable waterways. The programs can be used to generate potential routes based on a selection of point of origin, destination and selected constraints. DOE has made these programs available to States, Indian Tribes, national and regional organizations to assist in route evaluations and the designation of preferred routes (consistent with DOT regulations).

"...Rather than attempting to speculate on specific routes at this time, we believe it is more important to work collaboratively with representative organizations on a process and schedule for addressing routing issues. We are therefore proposing as a goal for next year a cooperative effort with States, Indian Tribes and representative groups to develop a schedule and process more specifically, a routing plan - for addressing routing during all phases of the waste management program... We plan to introduce specific ideas for this plan at a routing workshop expected to be held in late $1988 . .$.

"Assistance for training...Section 180(c) of the Amendments Act requires DOE to provide technical assistance and funds to States for the training of public safety officials in local governments and Indian Tribes through whose jurisdictions waste may be transported to a repository or monitored retrievable storage facility....

"We believe that the schedule for the development and operation of the overall waste management system affords the time necessary for carefully evaluating all issues related to training and the need for training assistance.

"This effort will be coordinated with the development of routing policies and the previously proposed routing plan and will be implemented in phases well ahead of waste disposal and storage facilities....

"In the area of emergency response, clarification of roles will initially be assisted by a DOE workshop planned for the spring of 1989 to review emergency response resources, issues and information needs. Topics of discussion are expected to include roles for emergency response, planning, training and equipment.

"Clarification of emergency response roles will further be assisted by DOE's development of a comprehensive document that describes the Department's emergency response equipment, personnel and procedures. DOE has developed over the years extensive emergency response capabilities in the event of any accident involving radioactive materials... DOE has eight emergency response regions nationwide, supported by numerous experts ready to respond to accidents. This capability can be mobilized within two hours of notification and dispatched to an accident scene anywhere in the continental United States. Arrival time of the emergency response resources is based on the travel distance required and the severity of the accident.
"DOE also sponsors emergency response workshops around the country on a regularly scheduled basis. Training covers first responder actions related to both general hazardous and radioactive material shipments. To date, over 5,000 people in 39 States have received DOE emergency response training....

"Prenotification ..... As required by Section 180(b) of the amended NWPA, DOE will comply with NRC shipment prenotification procedures when shipping waste to disposal and storage facilities. Current NRC regulations require that written notice be provided to States before spent fuel and highlevel radioactive waste are shipped within or through their borders. It should also be noted that DOE has committed to provide notice to Indian Tribes before shipping waste through their reservations, and is now evaluating the potential use of satellite tracking during transportation operations to supplement written prenotification and provide real-time shipping information.

\section{Cask Design and Testing}

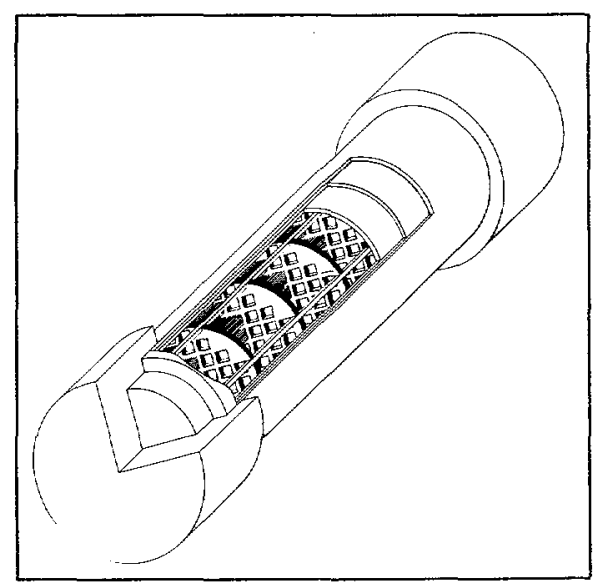

"DOE is proceeding with the design and development of "from-reactor" casks suitable for shipping waste either to a repository or to an MRS facility. Contracts are expected to be finalized (continued on page 5) 


\section{Excerpts from Recent Testimony by Charles E. Kay, Acting Director, OCRWM}

(continued from page 4)

in 1988 for the design of two legalweight truck casks and three rail-andbarge casks. The proposed designs promise a considerable increase in cask capacity, which in turn should result in a significant reduction in the number of trips required to move spent fuel.

"Initiatives are also planned for the design and development of casks suitable for (1) shipping waste from an MRS facility to a repository, (2) shipping non-standard fuel and fuel bearing components and (3) shipping high-level defense waste. Such initiatives will be implemented in the future on a phased basis.

\section{Support System Development}

"We have begun to evaluate alternative approaches for providing the support facilities, equipment and services needed for an operating transportation system. Specifications for a cask maintenance facility will be developed during cask design. The development of other support facilities, such as a control center for operations, will proceed as functional requirements of an operational transportation system are defined.

\section{Operations Planning}

"Operations planning has proceeded in two major areas: reviewing management options and evaluating the technical and procedural requirements for an operational transport system. Consistent with NWPA principles, we plan to use private industry to the maximum extent possible in managing future transportation operations. We, therefore, have initiated a preliminary review of potential management configurations and industry's willingness and capability to provide efficient management services....

\section{Conclusion}

"...the amended NWPA provides DOE with new guidance on the implementation of all aspects of the waste management program, including transportation. While the recent amendments to the NWPA established specific requirements for certain transportation activities, it should be noted that several of these new legislated requirements confirmed already established DOE policy in the use of NRC certified casks and NRC rules related to prenotification of shipments. In addition, the basic objectives of the transportation program have not changed. Those objectives call for DOE to develop a transportation system that is safe, secure and efficient, meets all applicable regulatory standards and provides opportunities for meaningful public participation in all phases of program planning. We believe that significant progress has been made to date in satisfying these objectives, and look forward to providing continued opportunities for coordinated planning with all interested parties...."

\section{Testimony Before the Nuclear Regulatory Commission}

(The purpose of this testimony, delivered on May 17, 1988, was to continue the practice of periodic presentations of OCRWM program activities and significant accomplishments to the NRC. In addition to reviewing some program highlights, e.g. the OCRWM reorganization (OCRWM Bulletin March/April 1988), the solicitation for a Management and Operating Contractor (OCRWM Bulletin March/April 1988), the issuance of the Site Characterization Plan/Consultation Draft (OCRWM Bulletin September 1987 and
November 1987) and the Dry Cask Storage Study (OCRWM Bulletin March/April 1988), the testimony addressed areas of joint and special NRC interest as highlighted below.)

\section{DOE/NRC Consultations}

"In addition to the consultations on the Site Characterization Plan/Consultation Draft (SCP/CD), we have also had other interactions, such as the recent DOE/NRC site visit, to observe the U.S. Geological Survey Southern Great Basin Seismic Monitoring Network....we have (also) completed a useful five-day workshop on Alternative Conceptual Models, a Quality Assurance (QA) meeting, and NRC staff has attended our Technical Project Office meetings and observed DOE audits of our contractors.

"Clearly, the value of consultations is accepted and recognized by the Department. We see as a priority nearterm consultation on the topics of quality assurance; the exploratory shaft location, design and construction; clarification of definitions in $10 \mathrm{CFR}$ $60 . .$. ; determination of methodology for calculating ground water travel time; and seismicity characterization methodology.

\section{Repository Design Parameters}

"...The NRC and DOE have agreed that, in developing the site characterization program, DOE will use performance allocation. In the words of the NRC staff, "DOE will select tentative values for the contributions that each of the natural and engineered barriers can reasonably be expected to provide to the overall waste isolation performance of the site. Such allocation is the rationale for (continued on page 6) 


\section{Excerpts from Recent Testimony by Charles E. Kay, Acting Director, OCRWM (continued from page 5)}

establishing specifically what information site characterization will have to produce.' It should be emphasized that these 'tentative values' are simply guides for developing a testing program and designs. As data is obtained and the site characterization program matures, these values may change.

“The NRC Position Point Paper and regular interactions between NRC and DOE staff are important vehicles for assessing how well DOE is implementing performance allocation. As the program matures, changes in our parameters will be reported in our semi-annual progress reports. While there may be some technical differences, I believe that the performance allocation process for guiding the site characterization program is currently proceeding well.

\section{Policy of Conservatism}

"With respect to alternative conceptual models for the Yucca Mountain site, DOE concurs with the NRC staff concerns and understands the basis for the objection. DOE and the NRC agreed to an approach to adequately address the concerns and rescind the objection, and DOE is currently implementing that approach in its revision of the SCP/CD....

\section{Early Resolution of Issues}

"Issue resolution is a key purpose of site characterization in order to demonstrate compliance with applicable Federal regulations. We concur with the NRC that a major goal of the high-level repository program is to ensure, to the extent practicable, resolution of licensing issues prior to the licensing hearing.

"To achieve that goal, we are developing a process of interactions with the staff that should lead to the early resolution of issues. This process includes the development of position papers for review with the staff, followed by reports that will consider the issue in greater depth and possibly, if warranted, rulemaking....

\section{Development of an Information Retrievable System}

"As you know, the Licensing Support System (LSS) computer system being developed by OCRWM to support the requirements of all parties in the repository licensing process will be based on a detailed set of system specifications. These specifications will be derived from statutory, programmatic and user requirements... Because of the importance and magnitude of the LSS, the Office of Management and Budget (OMB) has made development of the LSS system a top priority within the Executive Branch.

"As a first effort toward developing a sound requirements foundation for subsequent design work, (three) reports in a series of four reports have been issued by OCRWM. The Preliminary Needs Analysis and the Preliminary Data Scope constitute the system requirements basis for developing a conceptual LSS design, which (is) presented in the third report... The fourth report, a Benefit-Cost Analysis which will evaluate the conceptual (LSS) design alternatives, is scheduled for delivery to OMB with copies to the NRC and other parties in July.

"In addition to these studies, a multiuser prototype is to be tested both in Nevada and Washington, D.C., that will contain 120,000 pages of the SCP/CD and its over 2,000 associated references, as well as associated program documents all in full text with images of the pages of the documents. The prototype is expected to be available for use in early 1989.
"Building on these reports and later refinements, I am hopeful that we will be able to facilitate the discovery process and review of relevant licensing information for licensing proceedings; establish the information base for licensing proceedings before the license applications are submitted; and make it possible for the NRC to meet the statutory three year application review period....

\section{Implementation of a Quality Assurance Program}

"Policy guidance for the QA program is provided by the Director of OCRWM - a responsibility that I take with the utmost seriousness. To emphasize the importance of managing for quality, OCRWM has...established an Office of Quality Assurance to be managed by a Director who reports directly to the Director of OCRWM.

"Current goals of this new Office are to establish a qualified QA program by Jan. 1, 1989, secure approval of OCRWM's QA program by the NRC and achieve a favorable review of the QA program by the Nuclear Waste Technical Review Board when it becomes operative....

\section{State and Local \\ Government Interactions}

\section{Informal Cooperation}

"DOE has worked cooperatively with the State of Nevada in many forums. For example, State representatives have attended the Project Office's monthly technical project manager's meetings, arrangements were made for the contractors of the State to tour the Yucca Mountain site, a protocol has been established for their access, as appropriate, to the Nevada Test (continued on page 7 ) 


\section{Excerpts from Recent Testimony by Charles E. Kay, Acting Director, OCRWM}

(continued from page 6)

Site and office space near Yucca Mountain has been offered to State scientists....And of particular importance, the State attends all NRC/DOE meetings. DOE remains committed to maintaining positive, cooperative interactions with the State of Nevada and appropriate local governments.

\section{Consultation and Cooperation}

"DOE continues to hold open its offer to the State of Nevada to begin consultation and cooperation negotiations under Section 117 of the Nuclear Waste Policy Act. DOE reaffirms the general policy, goals and intentions that were contained in Section 4.2, "Consultation and Cooperation," of the 1985 Mission Plan.

\section{Benefits Agreements}

“...On Apr. 6, 1988, Secretary Herrington informed Governor Bryan of Nevada that DOE is prepared to enter into negotiations with Nevada on the development of a Benefits Agreement...Among other benefits, such an agreement would provide for State and local representation on a Review Panel with broad review and advisory responsibilities. It would also include a schedule of annual payments to Nevada.

\section{Financial Assistance}

"DOE intends to ensure that the State of Nevada and affected units of local government are adequately funded so that they may fully and effectively participate in the program...

"On Apr. 21, 1988, in response to a request from the Board of County Commissioners of Clark County which is contiguous with Nye County where the Yucca Mountain site is located, Secretary Herrington designated Clark County as an affected unit of local government. This will facilitate Clark County's active participation in the development of an acceptable repository site... .

\section{Conclusions}

"I hope that my discussion of program highlights and areas of joint and special concern has demonstrated that DOE will conduct the site characterization program so as to ensure sound management, efficient use of resources and above all the successful demonstration of regulatory compliance. Our approach will be determined, realistic and credible.

"...We fully expect that the NRC will be very demanding of the DOE program in order to develop the confidence and reasonable assurance that the public health and safety will be protected. We believe that a technically competent and astute regulator is in the program's best interest, and we have and will foster a healthy relationship of mutual respect with the NRC so that useful and constructive technical and policy exchanges can take place." 


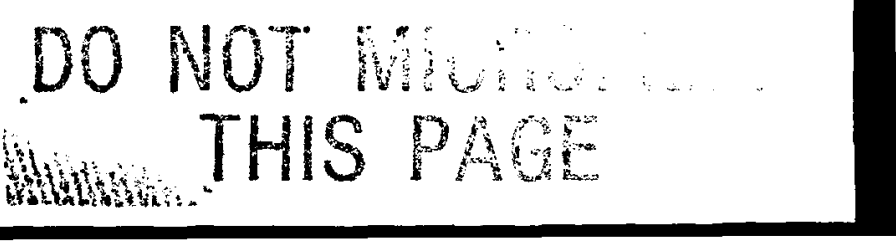




\section{OCRWM Bulletin}

United States Department of Energy Office of Civilian Radioactive Waste Management Washington, DC 20585

\section{Draft Mission Plan Amendment Issued for Comment}

Pursuant to section 301 of the Nuclear Waste Policy Act of 1982 (NWPA), DOE submitted a Mission Plan to Congress in July 1985. More recently, in June 1987, the Mission Plan was amended to explain significant developments and new information in the OCRWM program. As a result of the passage of the Nuclear Waste Policy Act of 1987 (Amendments Act), a draft 1988 Mission Plan Amendment (MPA) has been prepared by DOE. When finalized, the MPA will inform Congress of DOE's plans for implementing the new focus for the OCRWM program provided by the Amendments Act.

The MPA covers the general strategy for the waste management program as well as plans for both technical and institutional activities. More specifically it discusses such topics as:

- A description of the authorized waste management system, the development schedule for the waste management system and an explanation of the waste acceptance strategy for a system that consists of one repository and a Monitored Retrievable Storage facility.

- An explanation of how the technical plans and activities for the program elements have been changed by the Amendments Act and what principal developments have occurred since the June 1985 Mission Plan and the June 1987 Mission Plan Amendment.
- A description of institutional plans and activities including DOE's interactions with new organizations established by the Amendments Act, as well with those, such as the State of Nevada, with which there has been an established relationship. Also included are discussions of the transportation institutional program, consultation and cooperation and financial assistance.

- A discussion of how the new program will be managed.

The draft Mission Plan Amendment is being transmitted to the States, previously affected Indian Tribes, affected units of local government and Federal agencies. In addition, copies of the draft Amendment are being mailed for review and comment to nearly 7,000 addressees on the OCRWM mailing list who have previously expressed an interest in receiving program documents and status reports.

A copy of the Amendment may also be obtained by contacting any one of the DOE offices at the following addresses:

$$
\begin{aligned}
& \text { U.S. Department of Energy } \\
& \text { Office of Civilian } \\
& \text { Radioactive Waste Management } \\
& \text { Office of External Relations } \\
& \text { and Policy, RW-40 } \\
& 1000 \text { Independence Avenue, S.W. } \\
& \text { Washington; DC } 20585 \\
& \text { (202) 586-5722 }
\end{aligned}
$$

Nevada Nuclear Waste

Storage Investigations

Waste Management Project Office

U.S. Department of Energy

Nevada Operations Office,

Phase 2, Suite 200

101 Convention Center Drive

Las Vegas, NV 89109

(702) 295-8769

Repository Technology and

Transportation Division

U.S. Department of Energy

9800 South Cass Avenue

Argonne, IL 60439

(312) $972-2188$

(continued on page 5)

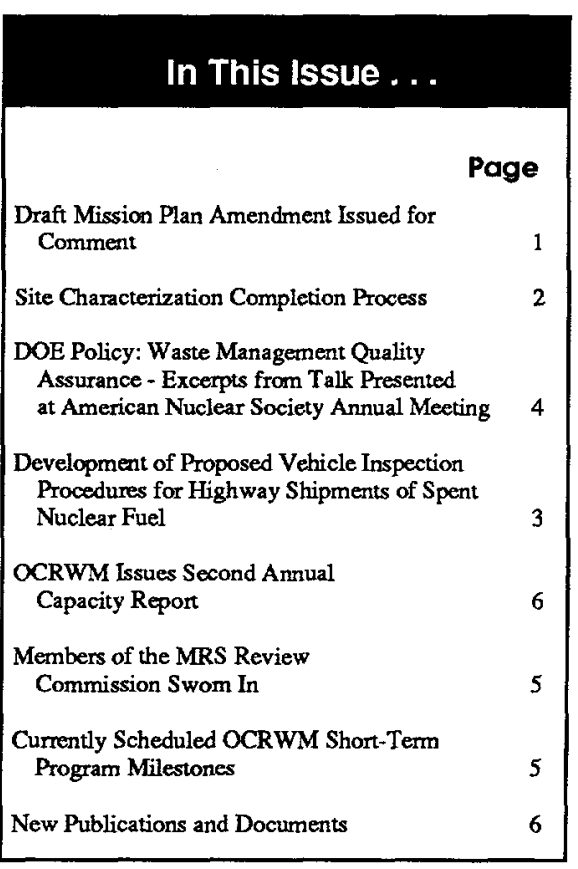




\section{Site Characterization Plan Completion Process}

Site characterization is the process to determine the suitability of the site for development as a repository and to provide information needed for licensing. Site characterization includes exploration and testing both at the surface and at the planned depths at which high-level nuclear waste will be emplaced. DOE's site characterization plan (SCP) for the Yucca Mountain site in Nevada is based on the requirements specified in the Nuclear Waste Policy Act of 1982 (NWPA) and 10 Code of Federal Regulations Part 60. In general, it is intended to:

- Describe the site, the preliminary designs of the repository and waste package and the waste emplacement environment in sufficient detail so that the basis for the site characterization program can be understood.

- Identify the issues (i.e., questions related to the performance and design of the repository) to be resolved during site characterization, establish the information needed and present the strategy for resolving these issues.

- Describe the general plans for the work needed to acquire and analyze the information in order to resolve the outstanding issues.

As a result of discussions with affected and interested parties, DOE concluded that the best interest of all parties would be served if an initial consultation process were conducted on the SCP. On Jan. 8, 1988, DOE issued its Site Characterization Plan/Consultation Draft (SCP/ CD) for the Yucca Mountain site in Nevada to serve as a vehicle for technical reviews. These reviews have been completed, and an SCP organization and completion process has been established to incorporate revisions and issue the SCP at the end of 1988 .

The organizational structure for completion of a statutory SCP is shown below.

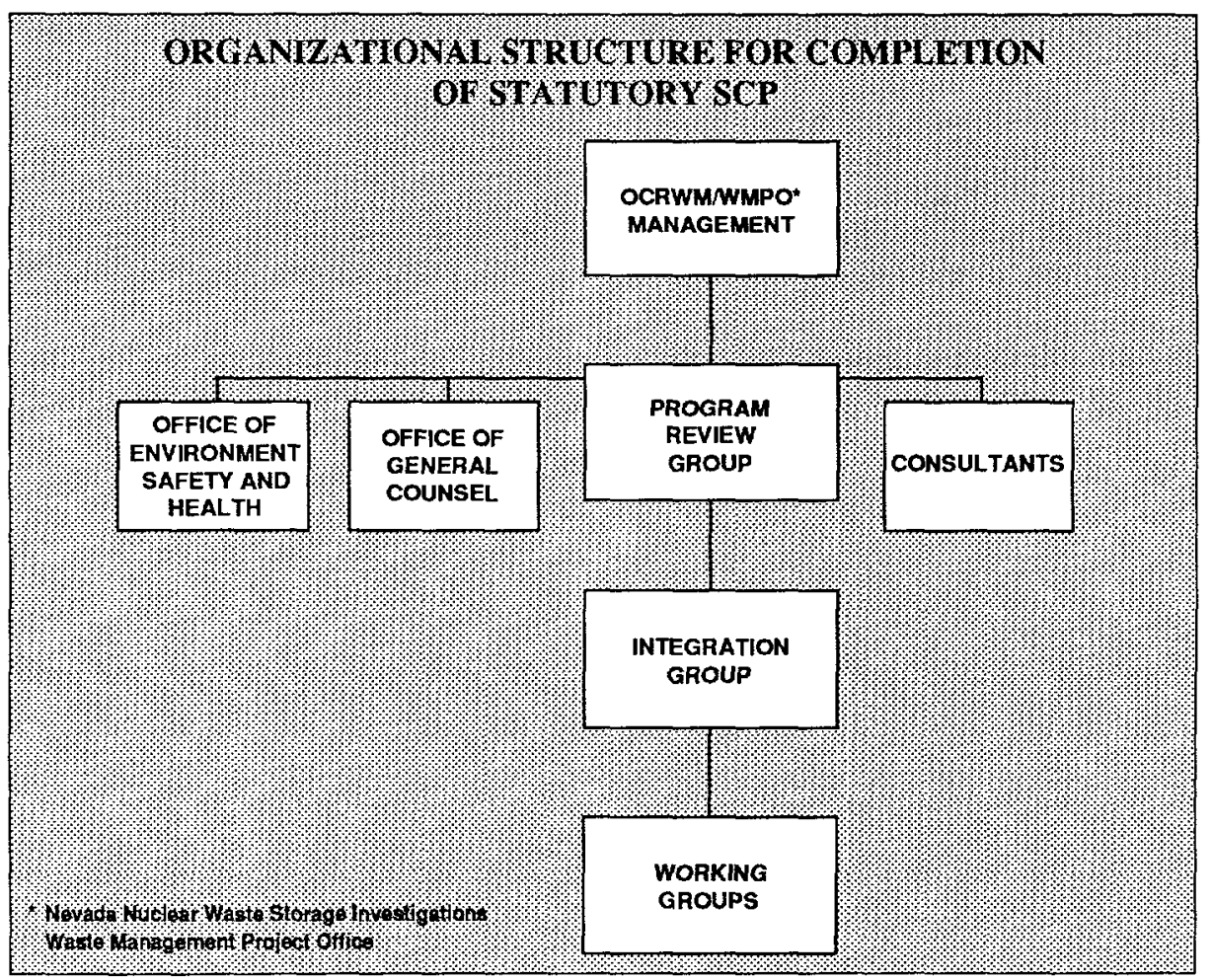

The SCP Program Review Group is responsible for assessing the integrated program, revisions proposed by the Integration Group and the Working Groups and proposed comment dispositions. It is also responsible for recommending revisions of the SCP to DOE management. Its membership consists of management level staff representing DOE Headquarters and Waste Management Project Office (WMPO) branches with responsibility for the SCP and the site characterization program: licensing, cost, schedule, geoscience, engineering and performance assessment.

The SCP Integration Group is responsible for providing guidance to the working groups, assessing evaluations of SCP/CD activities by the working groups, coordinating working group recommendations and making recommendations to the Program Review Group. Its membership consists of WMPO management staff, DOE Headquarters representatives and senior representatives from participating organizations, i.e., the U.S. Geological Survey, Sandia National Laboratories, Los Alamos National Laboratory, Lawrence Livermore National Laboratory and Science Applications International Corporation.

The SCP Working Groups assigned to specific technical areas are responsible for reviewing and evaluating SCP/CD activities, providing cost/schedule analyses and proposing text and program revisions. Its membership consists of top level WMPO representatives from licensing, cost, schedule, geoscience, engineering and performance assessment, with additional support and overview functions provided by DOE Headquarters representatives.

Quality control in the complex SCP completion process is addressed in SCP

(continued on page 3) 


\section{Development of Proposed Vehicle Inspection Procedures for Highway Shipments of Spent Nuclear Fuel}

The Commercial Vehicle Safety Alliance (CVSA), working through a cooperative agreement with OCRWM, is developing proposed vehicle inspection procedures for highway shipments of spent fuel. A Task Force representing CVSA members with expertise in motor carrier safety, hazardous materials transportation and driver qualifications completed the most recent draft inspection procedures in November 1987. The objective of CVSA and OCRWM in this project is to foster a system of uniformity and reciprocity in State vehicle inspections so that spent fuel shipments will be as safe and expeditious as possible.

For the next phase of this project, OCRWM is considering a pilot test of the current draft procedures using actual highway shipments. This inspection would be focused on the vehicle itself, and is not unique to spent fuel shipments. Therefore, spent fuel shipments are not required for this test. The Pacific States Agreement on Radioactive Materials Transportation Management (PSA) has volunteered to perform the pilot test. The PSA consists of the States of Idaho, Oregon and Washington. For a number of reasons, the PSA is well suited for the pilot test. For instance, there is a substantial amount of radioactive materials transportation within the PSA region because of activities at the Hanford reservation and at the nuclear facilities in Idaho Falls. The PSA States also have extensive experience in administering vehicle inspection and training programs.

Using the CVSA procedures to inspect highway shipments in the PSA region will provide a data base to test, evaluate and refine the procedures. The pilot test is expected to be a multi-year effort

\section{Site Characterization Plan Completion Process}

(continued from page 2)

management plans, written procedures for comment resolution, review and approval of comment disposition and text changes, and the participation of overview program groups and consultants to assure the adequacy and prudency of the site characterization program.

Numerous activities are taking place concurrently in completing the SCP. These activities include:

- Development of an internal issue closure methodology identifying:

- decision points and general criteria for termination of testing

- how information will be used to develop positions on issues and technical concerns

- approach to review of proposed positions

- $\mathrm{SCP} / \mathrm{CD}$ consultation process

- Internal review and analysis of the SCP/CD

- Schedule and cost analyses for site characterization activities

- Study plan development

Because of the importance of the SCP, the OCRWM Bulletin will carry a status report of the SCP completion process every other month beginning with this issue.

beginning in fiscal year 1989 . The initial activities will be devoted to preparation of a research design that will generate valid and reliable data. The PSA will develop a strategy to train inspectors in data collection, and may also develop a model training program for future highway vehicle inspectors.

While plans for the pilot test are being developed, OCRWM, CVSA and other organizations will continue to review the draft CVSA procedures. Comments have been received to date from the Western States Interstate Energy Board and the Utilities Nuclear Transportation Group.
When the pilot test is completed, the procedures will be refined as necessary. The last phase of the project calls for CVSA to formally adopt the procedures and to assist OCRWM in public interaction activities to ensure that they are uniformly accepted by all States. Tentative plans call for CVSA to develop a videotape and to hold regional meetings to discuss the procedures with State officials and other interested parties. Once adopted, the procedures can be updated and re-endorsed by CVSA if technological innovations or new program directions require. 


\section{DOE Policy: Waste Management Quality Assurance Excerpts from Remarks by William Kehew, OCRWM Office of Quality Assurance, before the American Nuclear Society Annual Meeting June 14, 1988, San Diego, CA}

\section{Quality Assurance Program Objectives}

"...The objectives are to provide confidence that the integrated radioactive waste management system will operate safely and isolate waste according to legislative and regulatory requirements and to help assure that these systems will perform other programmatic functions reliably and efficiently.

\section{OCRWM Quality Assurance Philosophy}

“...An effective program of quality assurance (QA) is essential for demonstrating that the technical performance of the waste management system and its elements meet regulatory standards. This demonstration is needed not only for obtaining from the Nuclear Regulatory Commission (NRC) the licenses needed for the repository and the Monitored Retrievable Storage (MRS) facility, as well as NRC certification for the transportation casks, but also for establishing public confidence in the technical quality of the program. We also believe that emphasis on quality assurance throughout the program will contribute to cost effectiveness. We, therefore, intend to implement a QA program that not only satisfies all NRC requirements but is completely integrated into every technical activity in the program and is completely documented.

"...OCRWM management fully appreciates the magnitude and complexity of the job ahead and has implemented systems and procedures for planning, scheduling, review and other required roles to provide close oversight and control of the program. Most important among these is its strong commitment to quality that must start at the top and flow down through the Headquarters line organizations, to the implementing Project Offices, to the performing contractor organizations and ultimately to the individual scientist, engineer or technician performing the work. OCRWM management must make a commitment to quality and be intimately involved in all phases of the program to assure its success.

"...OCRWM policy requires the establishment and implementation of documented and auditable QA programs by OCRWM Headquarters, Project Offices and Contractor line organizations to cover technical items and activities. To ensure that everyone will be working to uniform quality and related technical requirements, OCRWM is developing generic program guidance on the establishment of quality levels and the selective application of QA requirements. Program participants must describe the methodology for selecting the appropriate level or extent of QA controls to be applied to an item or activity within the scope of the program, based on its relative importance to safety, importance to waste isolation, or importance to program quality objectives.

"...Consistent application of QA requirements will not only ensure accomplishment of work by all participating organizations to the same required quality, but will also facilitate systematic verification of quality achievement.

"...An essential element of the development and implementation of the OCRWM QA program is the indoctrination and training of all personnel participating in OCRWM programs. The overall OCRWM plan envisions developing training modules and conducting training sessions to ensure that all personnel participating in the OCRWM program fully understand the management systems and their individual responsibilities for quality.

\section{Current Plans and Actions}

"...Revisions to the OCRWM QA program are currently in progress to (1) incorporate changes resulting from the Amendments Act, (2) reflect the new OCRWM organizational structure, (see OCRWM Bulletin, March/April 1988) and (3) complete the QA program development and implementation activities.

"...A primary example of OCRWM's commitment to quality assurance is reflected in the recent OCRWM Headquarters reorganization. The reorganization realigned the OCRWM Headquarters QA function by establishing an Office of Quality Assurance. The Director of the Office of Quality Assurance reports directly to the Director of the Office of Civilian Radioactive Waste Management.

The QA Director will have direct communications with the OCRWM Director and Associate Directors, Project Managers and other program management personnel to assure the achievement of the QA program objectives.

This will also provide added assurance that the official responsible for auditing and surveillance of quality-related activities reports independently to the highest level of the office. The QA Director is responsible for coordinating the development and maintenance of the OCRWM QA program. He is responsible for verifying through audits, surveillances and assessments that established QA programs are being implemented, are adequate and are an effective means of providing management with confidence that the $\mathrm{QA}$ program is functioning according to plan. The QA Director is also responsible for verifying and documenting that (continued on page 5) 


\section{Members of the Monitored Retrievable Storage Review Commission Sworn in}

Among the provisions of the Nuclear Waste Policy Amendments Act of 1987 was the establishment of a Monitored Retrievable Storage (MRS) Review Commission to prepare a report on the need for an MRS facility as part of a national nuclear waste management system. The report, together with the recommendations of the MRS Review Commission, is to be transmitted to Congress by June 1, 1989.

On June 14,1988 , Dr. Dale E. Klein, Dr. Frank L. Parker and Mr. Alex Radin were sworn in as members of the Commission by Speaker of the House, Jim Wright. The ceremony, conducted in Speaker Wright's offices, was attended by OCRWM Acting Director, Charles E. Kay; House Interior Committee Chairman Morris Udall; and key staff members of the Senate Energy and House Interior Committees. The first public meeting of the Commission is scheduled for July 25, 1988.

\section{Currently Scheduled OCRWM Short-Term Program Milestones}

July 1988

July/Aug. 1988

Sept. 1988

Dec. 1988

Dec. 1988

Dec. 1988
Issue Annual Capacity Report.

Issue initial version of Report on Dry Cask Storage for comment. Issue Fee Adequacy Evaluation to Congress.

Issue Yucca Mountain Site Characterization Plan to the public.

Issue Yucca Mountain Socioeconomic Impact Report to Congress.

Issue Revision 2 of Environmental Monitoring and Mitigation Plan.

For details on DOE/NRC meetings call (1/800) 368-2235 for a recorded message. In the Washington, DC, ares call 479-0487.

A telephone recording service has boen established for the amouncernent of upcoming meetings related to the waste managentent program of the NRC. the number is (1/800) 368-5642, Ext. 20436. Washington, DC, area residents should call $492-0436$.

Fox information on moetings undevents occuring between issues of the OCRWM Bulletin use OCRWM INFOLINK, an electronic bulletim board tbat can be accessed through a standard computer communications capability on (202) 586-9359. The OCRWM Bulletin is now available through INFOLINK.

\section{Draft Mission Plan Amendment Issued for Comment (continued from page 1)}

A copy of the draft Amendment to the Mission Plan is also available for public inspection at the above offices as well as at the following address:

\section{U.S. Department of Energy}

Public Reading Room, Room 1E-206

1000 Independence Avenue, S.W.

Washington DC 20585

Comments received on the draft Amend- ment to the Mission Plan will be available for public inspection at the Public Reading Room in Washington, $\mathrm{DC}$, at the above address. All comments received by Aug. 29,1988 , will be considered and changes will be incorporated as appropriate. Following the evaluation of the comments received, the final Mission Plan Amendment is scheduled for transmittal to Congress later this year.

\section{DOE Policy: Waste Management Quality Assurance \\ (continued from page 4)}

OCRWM has met all applicable regulations, statutes and other licensing requirements. Also, increased QA staffing levels have been authorized, and a QA support contractor is being used to assist OCRWM QA in the development and implementation of the QA program.

“...As part of the QA program development, OCRWM is currently engaged in prelicensing consultation with NRC to identify and resolve key QA issues, particularly those relating to the repository site characterization....The OCRWM Director has made a commitment to the NRC to have a fully qualified QA program in place for site characterization activities prior to the start of those activities.

"In order to facilitate the acceptance of the OCRWM QA program, Quality Assurance Coordinating Group (QACG) meetings will be re-initiated. These meetings were suspended in December 1987 pending the changes as a result of the Amendments Act.

"In order to assure that adequate QA provisions are in place for all site characterization activities, DOE will identify (1) those portions of the QA program required to support near-term site characterization activities, (2) the activities required toestablish and qualify those portions of the QA program and (3) the schedule for completion of those activities, commensurate with the schedule for site characterization activities. The initial plan and schedule will address near-term program activities and will be updated periodically to address subsequent program activities.

"This planned and scheduled approach to satisfying that commitment will allow both DOE and NRC to (1) monitor the

(continued on page 6) 


\section{OCRWM Issues Second Annual Capacity Report}

The Standard Contract for Disposal of Spent Nuclear Fuel and/or High-Level Radioactive Waste (10 Code of Federal Regulations 961) requires DOE to issue an Annual Capacity Report (ACR) for planning purposes. The ACR sets forth the projected annual receiving capacity of the Waste Management System (WMS) for 10 years following the projected commencement of facility operation and the annual acceptance ranking of spent nuclear fuel (SNF) and/ or high-level waste $(\mathrm{HLW})$ to be received by the WMS. This report is the second in the series of ACRs to be published by DOE.

The system configuration used as the basis for this year's report is the authorized system defined in the Draft 1988 Mission Plan Amendment (see article beginning on page 1 of this Bulletin). It includes an MRS facility as an integral system component. The illustrative waste acceptance schedule for this WMS configuration reflects the amended first repository schedule and a proposed schedule for the MRS facility. This schedule provides only an approximation of when and how the system will operate and is subject to changes as recognized in the Draft 1988 Mission Plan Amendment. During the first 10 years of WMS operation, the total quantity of spent fuel that could be accepted is projected to be 24,100 metric tons of uranium (MTU). The allocation of acceptance rights is currently based on the projected annual capacity of the WMS to receive SNF and the age of permanently discharged spent fuel as determined from 1986 data provided by the Purchasers of waste disposal services on the 1987 Nuclear Fuel Data Form, RW-859. The allocations are based on assigning the highest priority to the oldest fuel on an industry-wide basis.

The ACR allocates only that portion of the WMS capacity assigned to SNF and HLW originating from commercial reactors and covered by the Contract and/ or for which disposal fees have been paid. Commercial and defense high-level waste, spent fuel from non-commercial reactors and nonfuel wastes are not currently addressed.

Section 1.0 of the ACR provides a discussion of the requirement for the $A C R$ and the role it plays in DOE's interaction with Contract holders in implementing the provisions of the Standard Disposal Contract. The currently projected annual acceptance capacity to be allocated and a discussion of some of the impacts the Nuclear Waste

\section{New Publications and Documents}

\section{Draft 1988 Mission Plan Amendment, DOE/RW-0187, June 1988}

This draft 1988 amendment to the Mission Plan for the OCRWM program has been prepared to inform Congress of DOE's plans for implementing the provisions of the Nuclear Waste Policy Amendments Act of 1987 for the Civilian Radioactive Waste Management Program. This document is being submitted in draft form to Federal agencies, States, previously affected Indian Tribes, affected units of local government and the public. After consideration of comments, this amendment will be revised as appropriate and submitted to Congress.

\section{Annual Capacity Report, DOE/RW- 0191, June 1988}

The Annual CapacityReport sets forth the projected annual receiving capacity of the Waste Management System for 10 years following the projected commencement of facility operation and the annual acceptance ranking of spent nuclear fuel and/or high-level waste to be received by the Waste Management System. This report is the second in a series of Annual Capacity Reports to be published by DOE.
Amendments Act of 1987 may have on the Contract holders, DOE and the Contract are presented in Section 2.0. Section 3.0 discusses the basis and procedure for allocating this capacity (acceptance rights). The status of the ACR Issue Resolution Process and DOE responses to Contract holders' comments on the $1987 \mathrm{ACR}$ are discussed in Section 4.0. Annual capacity allocations, based on the chronological listing of spent fuel assembly final discharge dates, are summarized in Appendix A and detailed in Appendix B.

\section{DOE Policy: Waste Management Quality Assurance}

$$
\text { (continued from page 5) }
$$

progress of QA program development and implementation, (2) assure that QA program development and qualification activities are scheduled and completed consistent with their need and (3) schedule/allocate the necessary resources to complete the required activities.

"As stated previously, it is OCRWM's intention to have a fully qualified QA program in place prior to initiation of site characterization testing. This commitment was made with the understanding that fully qualified pertained to those activities that would result in collection of data and/or designs (hardware) that make up the licensing records and was based on the evolving nature of the repository program. Factors such as the extended time period over which site characterization will be performed, the sequential nature of many site characterization activities and the evaluation of the DOE/NRC interface, e.g., recent NRC notice of its intention to review and audit DOE prime contractor QA programs, make it clear that the DOE QA program will continue to develop over the next several years...." 


\section{OCRWM Bulletin}

United States Department of Energy Office of Civilian Radioactive Waste Management Washington, $D C 20585$

\section{NRC and DOE Sign Memorandum of Understanding for Cost Recovery}

The Nuclear Regulatory Commission (NRC) and the Department of Energy (DOE) signed a Memorandum of Understanding (MOU) in late July 1988 to establish general policy and procedures regarding the recovery by the NRC of costs it incurs in performing pre-license application activities related to the disposal of high-level radioactive waste and spent fuel in a geologic repository.

In Section 111 of the Nuclear Waste Policy Act of 1982 (NWPA), as amended, Congress made clear that while the Federal Government has the responsibility to provide for the permanent disposal of high-level radioactive waste and spent nuclear fuel, the costs of disposal should be borne by the generators and owners of the waste and spent fuel. To implement this policy, Congress in Section 302 of the NWPA established the Nuclear Waste Fund. The Fund consists of payments from the owners and generators of high-level radioactive waste and spent nuclear fuel. Section 302 authorizes the Secretary of Energy to make expenditures from the Fund for activities under Titles I and II of the NWPA. This would include appropriate reimbursement of the NRC costs.

Under the provisions of the MOU, reimbursement will be made from the Fund for all reasonable costs that are incurred by the NRC as a direct result of NRC's pre-license application consultations provided to the OCRWM program. Activities for which costs will be recovered by the $\mathrm{NRC}$ from the Fund are as follows:

- the development of NWPA regulatory requirements and technical guidance;

- the development of technical assessment capability for repository licensing reviews;

- the development and implementation of quality assurance/quality control and inspection programs for NWPA activities;

- site characterization reviews (conducting pre-license application reviews of OCRWM and OCRWM contractor NWPA activities, conducting pre-license application reviews of the environmental impact statement [EIS] resulting from the repository program including those activities required to make the EIS acceptable for adoption by the NRC);

- the review of transport packages certificate applications and technical issues related to package certification;

- the review of pre-license application activities related to the monitored retrievable storage (MRS) facility;

- the conduct of high-level waste research necessary to support the NRC regulatory activities directly related to the repository, MRS or transportation aspects of the program;

- activities relating to the disposal of defense high-level waste in the geologic repository;

- the costs of an independent auditor performing audits of NRC costs covered by this MOU; and

(continued on page 2)

\begin{tabular}{|lc|}
\hline \multicolumn{2}{|c|}{ In This ISSUe . . . } \\
\hline \multicolumn{2}{|c|}{ Page } \\
$\begin{array}{l}\text { NRC and DOE Sign Memo of } \\
\text { Understanding for Cost Recovery }\end{array}$ & 1 \\
$\begin{array}{l}\text { Stop Work Order Issued for U.S. Geological } \\
\text { Survey NNWSI Project Support }\end{array}$ & 2 \\
Status of Cask Design Effort & 2 \\
$\begin{array}{l}\text { Transportation ALARA } \\
\text { Report Available }\end{array}$ & 4 \\
Other Program Items & \\
$\begin{array}{l}\text { OCRWM Issues Annual Report } \\
\text { for Fiscal Year 1987 }\end{array}$ & 3 \\
$\begin{array}{l}\text { NRC High-Level Waste Advisory } \\
\text { Committe on Licensing Support System } \\
\text { Holds Final Meeting }\end{array}$ & 3 \\
$\begin{array}{l}\text { Public Comment Period Starts for Initial } \\
\text { Version of Dry Cask Storage Study }\end{array}$ & 3 \\
$\begin{array}{l}\text { Lake Barrett Designated to Serve as } \\
\text { Director, Office of Quality Assurance }\end{array}$ & 6 \\
$\begin{array}{l}\text { Currently Scheduled OCRWM Short-Term } \\
\text { Program Milestones }\end{array}$ & 5 \\
Selected Events Calendar & 4 \\
New Publications and Documents & 5 \\
\hline
\end{tabular}

Published by the U.S. Department of Energy (DOE), Office of Civilian Radioactive Waste Management (OCRWM)

For further information about the national program or for copies of new publications and documents listed in the OCRWM Bulletin contact the U.S. Department of Energy, OCRWM, Office of External Relations and Policy, Mail Stop RW-40, 1000 Independence Avenue, SW, Washington, DC 20585, (202) 586-5722. The OCRWM information Services Directory is available to provide sources of program information for the States, Indian Tribes, involved parties, and the public. 


\section{Stop Work Order Issued for the U.S. Geological Survey NNWSI Project Support}

During the course of a Waste Management Project Office Quality Assurance (QA) audit of the U.S. Geological Survey (USGS) project support for the Nevada Nuclear Waste Site Investigations (NNWSI), the audit team reviewed evidence and concluded that:

- the QA program currently in place is not being properly implemented in all areas; and

- in specific areas, the effectiveness of the QA program is questionable.

As a result of these findings, the following actions were taken on July 26, 1988.

- A stop work order was placed on the analysis, interpretation, publication and dissemination of data and information generated from the following activities: (1) site potentiometric level evaluation, (2) studies of calcite and opaline silica vein deposits, (3) current seismicity, (4) surface water runoff monitoring and (5) transport of debris by severe runoff.

All other tasks, including data collection for the preceding monitoring activities will continue. The sole exception to this provision is the calcite and opaline silica vein deposits study, for which sample collection is not authorized.

The stop work order will remain in effect until a readiness review, in which DOE is a direct participant, determines that the affected activities have been brought into full compliance with the provisions of the USGS NNWSI Project QA program.

- Further, an in-depth investigation will be undertaken to determine the extent to which the identified deficiencies in the QA program noted above apply to the balance of the QA Level I and II monitoring activities being conducted by the USGS. This investigation will commence by the submittal of a course of action plan(s) to the NNWSI Project Manager by Aug. 23, 1988. This plan will include the timetables, milestones, manpower requirements and criteria necessary to both detail the extent of the deficiencies and outline the measures necessary to correct them.

The activities affected by this stop order are crucial to the successful completion of the site characterization at Yucca confident that USGS can and will develop the required course of action plan(s) and implement corrective actions expeditiously. Mountain. The Project Office is

\section{NRC and DOE Sign Memorandum of Understanding for Cost Recovery \\ (continued from page 1)}

- that portion of the costs of the following that arise solely as a result of NRC's prelicense application consultations with the OCRWM program: (a) NRC staff's legal support for NWPA activities; (b) Atomic Safety and Licensing Board and Atomic Safety Licensing Appeal Panel expenses related to NWPA issues; (c) reviews of NWPA activities conducted by NRC's Advisory Committee on Nuclear Waste; and (d) services provided by NRC's Office of Governmental and Public Affairs related to NWPA issues.

In carrying out its responsibilities covered by this $\mathrm{MOU}$, the $\mathrm{NRC}$ will avoid unnecessary duplication of activities performed by DOE. Additional activities may be added to those listed above, after consultation between OCRWM and the NRC. The MOU also establishes procedures for billing and payment of costs incurred by the NRC.

\section{Status of Cask Design Effort}

OCRWM is proceeding with the design and development of casks suitable for shipping spent fuel from commercial reactor sites either to a repository or to a monitored retrievable storage (MRS) facility. OCRWM has now completed negotiations and signed five contracts for the design of "from-reactor" casks. The proposed truck and rail/barge casks have significantly greater carrying capacities than casks currently in use, and are expected to reduce the number of shipments to Nuclear Waste Policy Act waste management facilities.

The decision to develop overweight truck casks, originally planned as an element of the "from-reactor" cask development initiative, has been deferred until a later date. The development and demonstration of "dual-purpose" casks (casks that are technically and economically suitable for both storage and transportation) have been underway for several years as a result of both DOE and industry initiatives.

The first of the two truck cask design contracts was signed with General Atomics on Feb. 8, 1988, for $\$ 8.5$ million. Westinghouse Electric Corporation signed a contract for $\$ 7.7$ million on May 13,1988 . The three contracts for rail-andbarge casks were signed with Nuclear Assurance Corporation for $\$ 8.9$ million on Apr. 1, 1988; Nuclear Packaging, Inc., for $\$ 13.5$ million on May 10,1988 ; and with Babcock \& Wilcox for $\$ 14.9$ million on July $15,1988$.

Under the contracts, approximately two years will be devoted to preliminary and final design. After completion of the final design, two years will be needed for preparation of the Safety Analysis Report on Packaging and for review and certification of designs by the NRC. Three to five years are expected to be needed for the development of the cask prototypes and testing. DOE's Idaho

(continued on page 5) 


\section{Other Program Items}

OCRWM Issues Annual Report for Fiscal Year 1987

OCRWM has issued its Fifth Annual Report to Congress. The report, required by Section 304(d) of the Nuclear Waste Policy Act of 1982, covers the activities and expenditures of OCRWM during fiscal year 1987, which ended on Sept. 30, 1987.

Since the close of the fiscal year, a number of significant events have occurred. Foremost, was the passage of the Nuclear Waste Policy Amendments Act of 1987 (Amendments Act) on Dec. 21, 1987. As a result, some of the plans and activities discussed in chapters I through IX are undergoing significant change or are being discontinued. The refocusing of the waste management program under the Amendments Act is highlighted in the epilogue, chapter XI, to inform the reader of actions and events affecting the program since the end of the fiscal year. it

\section{NRC High-Level Waste Advisory Committee on the Licensing Support System Holds Final Meeting}

The final meeting of the NRC High-Level Waste Advisory Committee on the Licensing Support System (LSS) was held in Reno, NV, on July 20-21, 1988. The purpose of this Committee was to negotiate a proposed rule which would apply to the submission and management of records and documents related to the licensing of a geologic repository for the disposal of high-level radioactive waste.

Formal consensus on a proposed rule was not reached unanimously as the industry coalition participating in the meetings was unable to agree. However, the NRC staff will provide a strong recommendation to its Commission that a proposed rule be published in accordance with a draft rule that had the agreement of all parties except for the industry. This agreement was reached among the NRC, DOE, the State of Nevada, Nevada local governments, the National Congress of American Indians and a coalition of national environmental groups.

Publication of the draft rule is scheduled in September 1988 with a final rule at ihe end of the year.

Public Comment Period Starts for the Initial Version of the Dry Cask Storage Study

In accordance with the requirements of Section 5064 of the Nuclear Waste Policy Amendments Act, OCRWM has prepared an initial version of a report on the study and evaluation of the use of dry cask storage (and other technologies currently being considered) at reactor sites to meet the utility industry's spent nuclear fuel storage needs (see map below) through the start of operation of a permanent geologic repository (year 2003).

(continued on page 4)

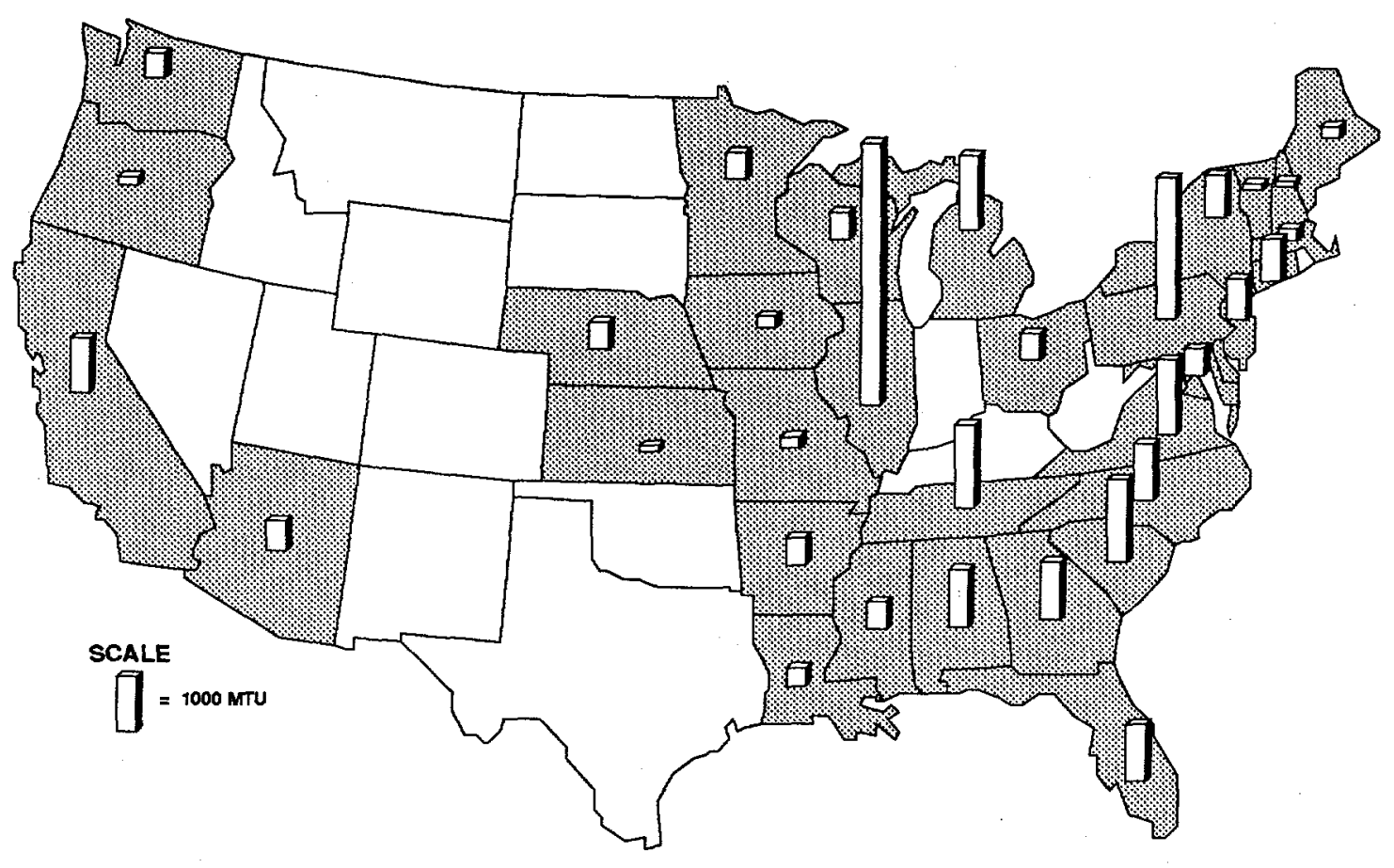

Distribution by State of the Maximum Additional At-Reactor Storage Requirements for the Reference Waste Disposal System Acceptance 


\section{Transportation ALARA Report Available}

The federal system for the management radioactive waste includes the acceptance by DOE of the spent fuel loaded intocasks at reactors, its transportation to a repository and its handling and final emplacement in the repository.

To assist in the development of an operational transportation system, OCRWM initiated an analysis of radiation doses to the public and to workers during normal transportation activities. While DOE will meet the regulatory limits for radiation doses, it will also consider meeting as low as is reasonably achievable (ALARA) principles as defined in proposed Nuclear Regulatory Commission (NRC) regulations appearing in 10 Code of Federal Regulations 20.3 and in the Federal Register Jan. 9, 1986. The OCRWM study, conducted by the Pacific Northwest Laboratory, gives estimates of the radiation doses expected using current and disposal of spent fuel and high-level equipment designs and transportation practices with proposed shipment statistics.

Study findings, published in a report entitled "Analysis of Radiation Doses from Operation of Postulated Commercial Spent Fuel Transportation Systems" (DOE-CH/TPO-001), are now available. The report contains an analysis of routine operations and estimates of public and worker radiation doses that system from commercial nuclear power reactors to a DOE repository using both truck and rail shipping. When finding dose producing activities in the postulated transport system higher than acceptable under ALARA principles, alternatives to that system were identified and evaluated. The analyses of these alternatives will be used by OCRWM to provide input to the development of a cost effective system, including the design and operation of the casks and interfacing facilities. might occur in a postulated transportation

Seventeen alternatives were identified to reduce the dose levels of individuals within the total system. These alternatives were evaluated individually to determine their related effect on operational times, radiation exposures and cost impacts. The alternatives developed with the highest system dose reduction were (1) those with increased cask capacity, such as overweight truck casks and advanced design casks, (2) increased end shielding on casks and (3) use of remote handling at the repository. Other alternatives resulting in significant dose reduction were special impact wrench tools, single action fasteners on cask lids and increased side shielding on truck casks.

The report is available from the Office of Scientific and Technical Information, U.S. Department of Energy, P.O. Box 62, Oak Ridge, TN 37831.

\section{Other Program Ifems \\ (continued from page 3)}

Sept. 19-23 Southern States Energy Board Bi-Annual Meeting, Carlsbad, NM. Contact Steve Kouba (312) 972-2263.

Oct. 12-13 National Academy of Sciences Board on Radioactive Waste Management, Washington, DC. Contact Charles Armstrong (202) 334-3068.

Oct. 24-26 15th Annual National Energy Division Conference (American Society for Quality Control), San Antonio, TX. Contact Robert Hartstern (201) 792-2400, ext. 223.

Nov. 9-11 Western Interstate Energy Board High-Level Waste Transportation Committee Meeting and Workshop, Denver, CO.

Contact Judy Holm (312) 972-2410.

For details on DOE/NRC meetings call (1/800) 368-2235 for a recorded message. In the Washington, DC, area call 479-0487.

A telephone recording service has been established for the amouncement of upcoming meetings related to the waste management program of the NRC. the mamber is (1/800) 368-5642, Ext. 20436. Washington, DC, area residents should call $492-0436$.

For information on meetings and events occuring between issues of the OCRWM Bulletin use OCRWM INFOL.INK, an electronic bulletin board that can be accessed through a standard computer communications capability on (202) 586-9359. The OCRWM Bulletin is available through INFOLINK.

\section{Selected Events Calendar}

The objectives of the Dry Cask Storage Study are:

- to consider the costs of dry cask storage technology, the extent to which dry cask storage at reactor sites will affect human health and the environment, the extent to which storage affects the cost and risk of transporting spent nuclear fuel to a central facility such as a monitored retrievable storage facility and any other factors that are considered appropriate.

- toconsider the extent to which amounts in the Nuclear Waste Fund can be used, and should be used, to provide funds to

(continued on page 6) 


\section{Currently Scheduled OCRWM Short-Term Program Milestones}

Aug. 1988 Issue initial version of Report on Dry Cask Storage

for comment.

Sept. 1988 Submit Annual Fee Adequacy Evaluation to Congress.

Nov. 1988 Submit 1988 Mission Plan Amendment to Congress

Dec. 1988 Issue Yucca Mountain Site Characterization Plan to the public.

Dec. 1988 Issue Yucca Mountain Socioeconomic Impact Report to Congress.

Dec. 1988 Issue Revision 2 of Environmental Monitoring and Mitigation Plan.

\section{New Publications and Documents}

Analysis of Radiation Doses from Operation of Postulated Commercial Spent Fuel Transportation Systems, DOE/CH/TPO-001, July 1988.

This report contains an analysis of routine operations and estimates of public and worker radiation doses that would occur in a postulated transportation system from commercial nuclear power reactors to a DOE repository using both truck and rail shipping. When finding high dose producing activities in the postulated transport system, alternatives to the system were identified and evaluated. The report is available from the Office of Scientific and Technical Information, U.S. Department of Energy, P.O. Box 62, Oak Ridge, TN 37831.

\section{OCRWM Annual Report, DOE/RW-0189, August 1988.}

This report is the fifth annual report to Congress. The report covers the activities and expenditures of OCRWM during fiscal year 1987, which ended on September 30, 1987. The refocusing of the waste management program under the Nuclear Waste Policy Amendments Act is highlighted in the epilogue, Chapter XI, to inform the reader of actions and events affecting the program since the end of the fiscal year 1987.

OCRWM Transportation Program Reference; Glossary, Acronym List, Bibliography, DOE/RW-0193, July 1988.

This booklet has been developed to assist in the exchange of information and to help in the communication of issues for the public understanding of the transportation system for nuclear waste. It provides a glossary of commonly used terms, a list of acronyms, a bibliography selected from the public information developed by the OCRWM program and contacts for additional information.

\section{Managing the Nation's Nuclear Waste, DOE/RW-0195, July 1988.}

This brochure answers some of the most commonly asked questions about the nuclear waste management program. The answers provide a brief overview on topics including the Nuclear Waste Policy Act of 1982, geologic repositories and site selection in terms appropriate for the general public. Revised reprint.

$$
\text { (continued on page 6) }
$$

\section{Status of Cask Design Effort \\ (continued from page 2)}

Operations Office will provide the dayto-day coordination and technical direction of the cask development contractors.

Opportunities will continue to be provided for public input in the cask design and development process. DOE will provide briefings on preliminary and final design activities at meetings of the Transportation Coordination Group and provide copies of related technical and topical reports to interested parties. In addition, copies of draft and final Safety Analysis Reports and copies of NRC comments on the reports will be made available for review.

The development of "from-reactor" casks suitable for shipping waste either to an MRS or a repository facility is just one of the four major initiatives planned for the design and development of transportation casks. The other three initiatives are (1) casks for shipping exclusively from an MRS facility to a repository, (2) casks for non-standard fuel and non-fuel bearing components and (3) casks for shipping high-level waste.

The design and development initiatives for other casks needed in the waste management program will proceed on a phased basis. For example, the development of the MRS-to-repository casks will begin once a decision on fuel rod consolidation at the MRS has been made. The requirements for casks that will carry non-standard and non-fuel components will be defined during the development of the "from-reactor" casks. The products of the "from-reactor" initiative will be analyzed to determine what waste, if any, cannot be handled by the family of casks. Work on casks for shipping high-level waste will also be initiated after DOE determines whether it will be necessary to develop new casks or to modify existing "from-reactor" casks. 


\section{Other Program Items}

(continued from page 4)

construct, operate, maintain and safeguard spent nuclear fuel in dry cask storage at reactor sites.

- to consult with the NRC and include its views in the report; and

- to solicit the views of State and local governments and the public.

In late August 1988, DOE published in the Federal Register a notice intended to facilitate the participation of State and local governments and the public by notifying them that the initial version of the report is available for their review and comment. Those interested in receiving a copy of the report or submitting comments should write to Mr. Charles Head, U.S. Department of Energy, Office of Civilian Radioactive Waste Management, RW-322, Forrestal Building, 1000 Independence Avenue, S.W., Washington, DC 20585. Comments are due by Oct. 28, 1988.

After reviewing the comments received, DOE will make appropriate modifications in the report before it is submitted to Congress.
Lake Barrett Designated to Serve as Director, Office of Quality Assurance

The development and implementation of the OCRWMQuality Assurance program is essential to the overall success of the integrated management system. Accordingly, OCRWM's Acting Director, Charles E. Kay, has designated Lake Barrett, who is currently assigned as Acting Deputy Associate Director, Office of External Relations and Policy, to serve as Director for the Office of Quality Assurance. In addition, several members of the OCRWM staff have been detailed to the Office of Quality Assurance to assist in the quality assurance effort.

Mr. Barrett and members of the Office of Quality Assurance are charged with the establishment and implementation of a quality assurance program that will become an effective working vehicle for OCRWM and will foster and strengthen DOE's relationship with the NRC.

\section{New Publications and Documents \\ (continued from page 5)}

Technical Position on Items and Activities in the High-Level Waste Geologic Repository Program Subject to Quality Assurance Requirements, NUREG-1318, April 1988.

The purpose of this technical position paper is to provide Nuclear Regulatory Commission staff positions on quality assurance criteria for licensing, the types of analyses appropriate to determine which items and activities are important to safety and/or waste isolation, the staff information needs to assure adequate and timely staff involvement and the graded application of quality assurance measures to items and activities important to safety and/or waste isolation. The report is available from the National Technical Information Service, Springfield, VA 22161. 
United States Department of Energy Office of Civilian Radioactive Waste Management Washington, $D C 20585$

September 1988

\section{Congress Enacts Appropriation for Nuclear Waste Program For Fiscal Year 1989}

On July 19, 1988, Public Law 100-371 was enacted that included, among other appropriations for Fiscal Year 1989, $\$ 369,832,000$ for nuclear waste disposal activities to be derived from the Nuclear Waste Fund. This appropriation is allocated to the following programmatic activities:

\section{Nuclear Waste Fund}

First Repository

Operating expenses

Capital purchase

Construction

Subtotal

Second Repository

Operating expenses

Capital purchase

Construction

Subtotal

Monitored Retrievable Storage

Operating expenses

Capital purchase

Construction

Subtotal

Transportation and Systems Integration

Operating expenses

Capital purchase

Construction

Subtotal .

Program Management and Technical Support

Operating expenses .....................................

Capital purchase

Construction

Subtotal

Total Program

Nuclear Regulatory Commission Fees

Total Nuclear Waste Fund

Several limitations on expenditures were included in the legislation:

- Of the amount appropriated, no more than $\$ 11$ million, at an annualized rate, may be provided to the State of Nevada for the period July 1, 1988 through June 30, 1989, for the conduct of its oversight responsibilities pursuant to the Nuclear Waste Policy Act of 1982 as amended, of which not more than $\$ 1.5$ million may be expended for socioeconomic studies and not more than $\$ 1.5$ million may be expended on transportation studies.

- No more than $\$ 5$ million, at an annualized rate, may be provided to local governments to conduct appropriate activities.

\section{In This Issue...}

$\begin{array}{rr}\$ 4,000 & \$ 15,000 \\ 0 & 0 \\ 0 & 0 \\ \$ 4,000 & \$ 15,000\end{array}$

$\begin{array}{rr}\$ 37,000 & \$ 40,600 \\ 0 & 400 \\ 0 & 0 \\ \$ 37,000 & \$ 41,000\end{array}$

$\$ 56,800$

2,700

$\$ 59,500$

$\$ 71,732$

$\$ 75,132$

$\$ 360,000$

$\$ 354,832$

15,000

$\$ 369,832$

$\$ 360,000$

0

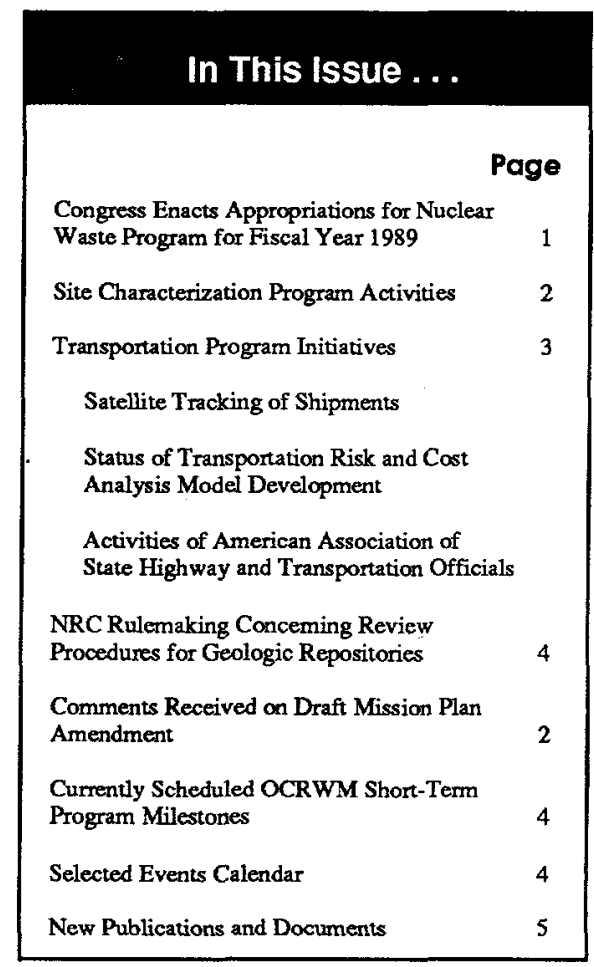

Published by the U.S. Department of Energy (DOE), Office of Civilian Radioactive Waste Management (OCRWM)

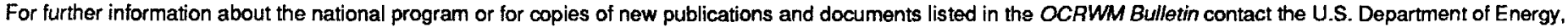
OCRWM, Office of External Relations and Policy, Mail Stop RW-40, 1000 independence Avenue, SW, Washington, DC 20585, (202) 586-5722. The OCRWM information Services Directory is available to provide sources of program information for the States, Indian Tribes, involved parties, and the public. 


\section{Site Characterization Program Activities}

The purpose of site characterization is to determine whether the Yucca Mountain site in Nevada is suitable for the Nation's first geologic repository for high-level radioactive waste. To achieve this objective, an organizational structure has been established and a site characterization plan (SCP) is being developed as described in the July issue of the OCRWM Bulletin.

Although the Nuclear Waste Policy Act (NWPA) calls for DOE to develop a "general plan" for site characterization, DOE has chosen to go well beyond this requirement, chiefly to provide the Nuclear Regulatory Commission (NRC) with enough information to enable them to determine whether the site characterization program is likely to provide the information they need to conduct the licensing process. The resulting SCP will run to several thousand pages in length, is supported by several thousand reference items, presents available geotechnical information about the site and will describe the conceptual designs for the engineered features and the plans for characterizing the site.

To generate the information needed to establish the suitability of the Yucca Mountain site, a site characterization program has been designed consisting of the following major activities:

- Investigation of the physical characteristics of the site and analysis of both the new data generated and data already available to determine more exactly the nature of the site characteristics. To determine physical site characteristics, both subsurface and surface-based investigations will be conducted. At the heart of the site investigations will be an exploratory shaft facility consisting of two shafts. One will be used for almost all of the testing; the other primarily for service and safety purposes. At the main test level, three long exploratory drifts will be excavated that will allow testing within the proposed repository horizon and over a substantial portion of the proposed areal extent of the repository excavation.

- Refining models for predicting how the natural features of the site and each of the engineered barriers will perform, both individually and together, for the next 10,000 years. DOE will be documenting the results of the performance assessments in a series of position papers and reports, some of which will serve as a basis for consultations with the NRC and other parties. The documents will also be used in developing the Safety Analysis Report that will be part of DOE's license application to the NRC.

In addition to investigating the physical characteristics of the site, OCRWM is engaged in the design of the engineered features of the disposal system, tailoring each to the physical conditions of the site. The engineered features include the underground repository facility, the waste package and a system for permanently sealing the repository. The design of the repository, waste package and seals system will proceed through four distinct stages: (1) preliminary conceptual designs for the engineered elements of the repository, (2) advanced conceptual designs, (3) designs described in the license application to the NRC and (4) the final designs to be used to actually procure and construct the engineered components of the system.
Because of the complexity of the SCP, an initial consultation process and technical review was conducted through the issuance in January 1988 of a site characterization plan/consultation draft. This review has been completed, and revisions to the SCP, in response to the external comments received and continuing internal evaluations, are being considered. The revision process was iterative and involved workshops to consider the merits of the comments; drafting of changes to the SCP followed by reviews before various management panels described in the July OCRWM Bulletin. Among the major topics addressed by these panels were:

\section{- Alternative conceptual models}

- Exploratory shaft facility construction/ testing interference/impacts

\section{- Performance confirmation}

- Total-system radioactivity releases

- Substantially complete containment

- Schedules

At the present time, it is expected that a final draft of the SCP will be available in late September. The concurrence review by Headquarters staff of OCRWM is scheduled to begin in October with completion in November. The current plan is for printing to take place in December, with issuance of the SCP in late December.

\section{Comments Received on Draft 1988 Mission Plan Amendment}

The public comment period on the draft 1988 Mission Plan Amendment has closed. Approximately 40 letters with comments have been received. Responding to the request for comments were replies from State and Local Governments (20), interest groups (11), utilities (3), private citizens (3), Indian Tribes (2) and one Federal agency. The NRC and the State of Nevada have advised that their comments will be forthcoming. Copies of the letters have been placed in the DOE reading room. 


\section{Transportation Program Initiatives}

Satellite Tracking of Shipments

Current Nuclear Regulatory Commission (NRC) regulations require that written prenotification be provided to States before spent fuel or high-level waste is shipped within or through their boundaries. Also under consideration by OCRWM is the use of a real-time shipment tracking system of Nuclear Waste Policy Act (NWPA) shipments as a method for supplementing the NRC prenotification requirements and providing emergency response information.

DOE's Office of Defense Programs is developing a satellite transportation tracking and communication system to monitor the movement of radioactive material shipments. The system, known as TRANSCOM, is being developed to enhance DOE's management oversight and operational control over shipments of radioactive materials. The TRANSCOM satellite tracking system will use a U.S. Coast Guard LORAN-C Navigation System, antenna assemblies, satellites and satellite earth stations. TRANSCOM is expected to be operational by October 1988 to support the opening of the Waste Isolation Pilot Plant in New Mexico.

In full operation, TRANSCOM provides position location information and twoway messaging capability between the TRANSCOM Control Center and the vehicle. In addition to receiving the location information every 15 minutes, the use of TRANSCOM allows the user to access other vital information through an extensive data base. For an individual shipment, TRANSCOM users could access shipment schedules, planned routes and the type of radioactive material contained in the shipment. Key emergency contacts at DOE Headquarters and the DOE field office closest to the shipment would be listed for each shipment. The TRANSCOM system will be available to authorized users.

Tracking and message receiving capabilities for TRANSCOM were demonstrated by DOE in April 1988, and user training began in May 1988. A control center is being set up in Oak Ridge, TN.

Following development of the TRANSCOM system, OCRWM will evaluate the feasibility of applying the TRANSCOM system to NWPA shipping.

\section{Status of Transportation Risk and Cost Analysis Model Development}

One of OCRWM's objectives is to design a transportation system for spent nuclear fuel and high-level radioactive waste that is safe and cost-effective. In support of this objective, a computer code has been developed that analyzes the transportation system on the basis of lifetime risk and cost. The code, known as the Transportation Risk and Cost Analysis Model (TRICAM), will be used to support decision making during the current planning stage of the OCRWM transportation program.

TRICAM is a constrained optimization code that models the transportation cask handling and storage components of the overall OCRWM waste management system. Each activity (such as cask loading and hauling) is modeled in terms of three variables - radiation dose, costs and constraints. Examples of constraints include the minimum age of the spent nuclear fuel before it would be transported, the quantity of fuel that can be handled annually at the repository, capacities of the transportation casks and pool capacities. For any given set of radiation doses, costs and constraints, TRICAM computes the optimum set of "paths" for getting the spent nuclear fuel from the sources - the waste generator sites - to its ultimate repository destination. These paths include, in addition to transportation, storage in pools and dry casks and fuel consolidation and packaging.

TRICAM will be used by DOE as a planning and decision support tool. The primary advantage of TRICAM is that it enables the comparison of alternative scenarios-system, equipment and schedule options - in terms of their lowest achievable risks and costs. A preliminary version of TRICAM was completed in April 1988 and has been tested intensively. Code documentation is expected to be completed by the end of 1988 .

\section{Update on Activities of the American Association of State Highway and Transportation Officials (AASHTO)}

AASHTO is working on a number of initiatives for expanding national truck transport uniformity. One element of this program is evaluation of the feasibility of a uniform permitting system for overweight truck shipments of spent nuclear fuel. Most States require special permits, which vary from State to State, and impose operating restrictions for trucks that exceed 80,000 pounds gross vehicle weight. The AASHTO Task Force on Truck Size and Weight Regulation is leading this effort to achieve uniformity.

The Task Force, which includes State officials representing each of AASHTO's four regions, is working in cooperation with DOE, the Federal Highway Administration and the International Bridge, Tunnel and Turnpike Association (IBTTA). The Task Force held its third meeting on Mar. 9, 1988, in Dallas, TX.

(continued on page 5) 


\section{NRC Rulemaking Concerning Review Procedures for Geologic Repositories and Disposal of Certain Low-Level Radioactive Waste}

\section{Review Procedures for Geologic Repositories (10 Code of Federal Regulations 51)}

The Nuclear Regulatory Commission (NRC) has issued for comment a notice of proposed rulemaking concerning review procedures for geologic repositories under the National Environmental Policy Act (NEPA) and the Nuclear Waste Policy Act (NWPA), as amended. The proposed rule:

- addresses the NRC role under the NEPA in connection with a license application submitted by DOE for a geologic repository for high-level waste;

- reflects the provisions of the NWPA, as amended, which require the NRC to adopt DOE's environmental impact statement (EIS) to the extent practicable; and

- sets out the standards and procedures that would be used in determining whether such adoption is practicable.

Disposal of Greater-than-Class-C (GTCC) Low-Level Waste (10 Code of Federal Regulations 61)
The NRC is proposing two changes to its existing rules. First, it would require all GTCC waste to be disposed of in a geologic repository unless an alternative proposal is approved by the NRC. Second, the jurisdictional reach of 10 CFR 61 would be extended to cover all activities of DOE that may be subject to the licensing and regulatory authority of the NRC.

Copies of the comments received by the $\mathrm{NRC}$, including those of $\mathrm{DOE}$, may be examined at the NRC Public Document Room, 1717 H Street, NW, Washington, DC.

\section{Currently Scheduled OCRWM Short-Term Program Milestones}

Dec. 1988 Submit Yucca Mountain Site Characterization Plan to the Governor of Nevada, the NRC and the public.

Submit Dry Cask Storage Study Report to Congress.

Issue Yucca Mountain Socioeconomic Impact Report to Congress.

Issue Revision 2 of Environmental Monitoring and Mitigation Plan.

Issue final Report to Congress on evaluation of lead as a potential waste package material.

\section{Selected Events Calendar}

Oct. 12-13 National Academy of Sciences Board on Radioactive Waste Management Meeting, Washington, DC.

Contact Charles Armstrong (202) 334-3068.

Oct. 24-26 15th Annual National Energy Division Conference (American Society for Quality Control), San Antonio, TX.

Contact Robert Hartstern (201) 792-2400, ext.223.

Oct. 30- American Nuclear Society/European Nuclear Society International Conference, Washington, DC.

Nov. 4 Contact Meetings Department (312) 352-6611. An OCRWM exhibit will be shown at this conference.

Nov. 9-11 Western Interstate Energy Board High-Level Waste Transportation Committee Meeting and Workshop, Denver, CO. Contact Judith Holm (312) 972-2410.

Dec. 7-8 Transportation Coordination Group Meeting, Hyatt Regency Hotel, Kansas City, MO. For reservations, contact the hotel at (816) 421-1234. Contact Beth Darrough (202) 586-5616.

For details on DOE/NRC mectings call (1/800) 368-2235 for a recorded me ssage. In the Washington, DC, area call 479-0487.

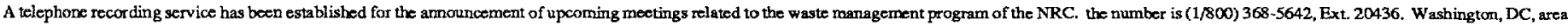
residents should call 492-0436.

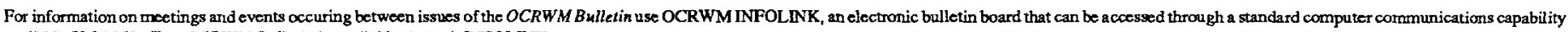
on (202) 586-9359. The OCRWM Bulletin is available through INFOLINK. 


\section{New Publications and Documents}

\section{Analysis of Institutional Issues and Lessons Learned from Recent Spent Nuclear Fuel Shipping Campaigns, BMI/OTSP-03, May 1988}

This report identifies institutional issues that surfaced during ten spent fuel rail and highway shipping campaigns, analyzes the measures taken to avoid or resolve problems and abstracts lessons that may apply to future shipments. Information was provided by interviews with shippers, carriers, receivers and licensees involved in the campaigns.

The major institutional issues encountered during the course of the ten campaigns included routing, overweight truck permitting, documentation of environmental impacts, escorts, inspections, cask safety and certification and prenotification procedures. The study analyzes the actions taken in response to these issues and formulates lessons learned in three categories: campaign and public information planning and coordination, shipment policy and procedures, and State and local interactions.

To obtain a copy of the report, contact the Office of Transportation Systems and Planning, Battelle Memorial Institute, 505 King Avenue, Columbus, OH 43201-2693.

\section{Managing the Nation's Nuclear Waste, DOE/RW-0192, August 1988}

The Nuclear Energy Agency (NEA) of the Organization for Economic Cooperation and Development seeks to promote cooperation between member governments on the safety and regulatory aspects of nuclear development and on the role of nuclear energy as a contributor to economic progress. As part of this cooperation, DOE has prepared a brochure describing its national program for disposing spent fuel and high-level radioactive waste. Similar brochures have been prepared by the Swiss and Swedish governments and are available on request from U.S. Department of Energy, Office of External Relations and Policy, Mail Stop RW-40, 1000 Independence Avenue, SW, Washington, DC 20585, (202) 586-5722. Other brochures are being developed by other cooperating governments and will be announced in the OCRWM Bulletin when available for distribution.

\section{Initial Version Dry Cask Storage Study, DOE/RW-0196, A ugust 1988}

This initial version of the report on the use of dry cask storage technology at the sites of civilian nuclear power reactors has been prepared in response to the requirements of the Nuclear Waste Policy Amendments Act of 1987 that, among other things, directs the Secretary of Energy to conduct a study and evaluation of dry cask storage. This initial version of the report is being issued for review and comment by State and local governments, utilities, other interested parties and the public. It is also being submitted to the Nuclear Regulatory Commission (NRC) for review and comment. After comments are received, the report will be revised as appropriate and again submitted to the NRC for final review and comment. After comments of the NRC have been received, the final report together with the views of the NRC will be submitted to Congress.

To obtain a copy of the report, contact the U.S. Department of Energy, Office of External Relations and Policy, Mail Stop RW-40, 1000 Independence Avenue, SW, Washington, DC 20585, (202) 586-5722.
Update on Activities of the American Association of State Highway and Transportation Officials (AASHTO) (continued from page 3)

The group's findings and recommendations will provide input to OCRWM's decision on the role of overweight trucks in the NWPA shipping program.

At the Dallas meeting, the Task Force chairman reported that the AASHTO Policy Committee recently approved a resolution endorsing uniformity in the permitting of overweight truck casks used to transport spent nuclear fuel. The Policy Committee also approved a resolution defining the cask and payload of spent nuclear fuel as a non-divisible load. In November 1987, the Federal Highway Administration informed OCRWM that it considered casks and their payload as non-divisible loads, thereby allowing States to permit the shipments without jeopardizing Federal-aid highway funding.

As a first step toward State acceptance of uniform overweight permitting, the Task Force has been developing a conceptual vehicle design that would have the greatest potential for nationwide acceptability. The Task Force narrowed the range of options for the conceptual vehicle design through questionnaires and informal contacts with State permitting officials. The Task Force also coordinated with OCRWM officials representing the Cask Systems Design Program and the Transportation Operations Program to ensure that NWPA shipping needs are accommodated.

The next step for the Task Force is to contact the chief administrative officers of State transportation departments and IBTTA member authorities for more formalized information about State permitting practices and to identify potential obstacles to uniformity. The Task Force plans to submit a recommendation to OCRWM by mid-1989 on the feasibility of uniform permitting. The next Task Force meeting is tentatively scheduled for late fall 1988. 


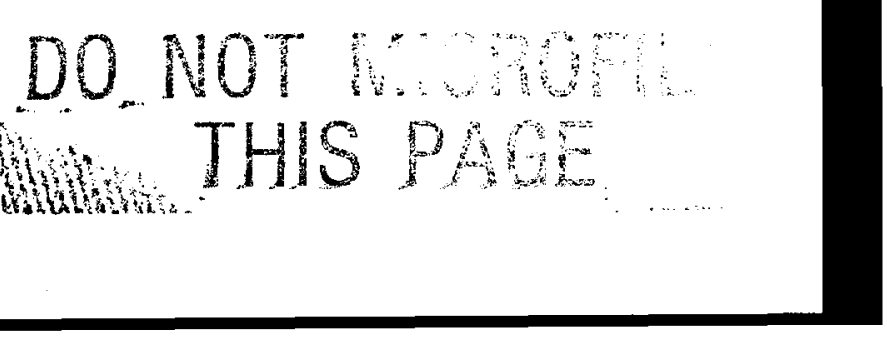




\section{OCRWM Bulletin}

United States Department of Energy Office of Civilian Radioactive Waste Management Washington, DC 20585

October/November 1988

\section{Samuel Rousso Appointed Acting Director of OCRWM; Franklin G. Peters Appointed Deputy Director}

Samuel Rousso has been appointed Acting Director of the Office of Civilian Radioactive Waste Management (OCRWM), succeeding Charles E. (Ed) Kay, who has moved to a senior position at the U.S. Department of the Interior. Mr. Kay served as OCRWM's Deputy Director since February 1985, and became OCRWM's Acting Director in November 1987. He leaves to become the Interior Department's Principal Deputy Assistant Secretary for Policy, Budget and Administration.

Mr. Rousso has worked in the civilian radioactive waste management program since 1986 and most recently has been Associate Director of OCRWM's Office of Program Administration and Resources Management. Prior to this position, he was in the private sector as a senior staff member providing management consulting expertise for large and complex technical programs. Mr. Rousso was Chief Planning and Financial Officer for Defense Programs in the Department of Energy (DOE) and its predecessor agencies from 1976-1983. He also served as a Scientific Advisor for the Atomic Energy Commission in Europe. During the six years of this service, his major activities centered on nuclear power, nuclear waste management and other nuclear energy issues.

\section{MRS Review Commission Announces Public Hearing Dates and Locations}

The Monitored Retrievable Storage Review Commission will hold public hearings to obtain the views of the public on the need for a Monitored Retrievable Storage (MRS) facility as part of the Nation's nuclear waste management system.

The dates, locations and times of the hearings reported by the Commission are:

- Dec. 1-2, 1988, in Washington, DC, at the Rayburn House Office Building, Room 2322, Independence Avenue, between South Capitol Street and First Street S.W., from 10:30 a.m. - 5:00 p.m.

- Jan. 5, 1989, in Denver, CO, at the Stouffer Concourse Hotel, 3801 Quebec Street, (303) 399-7500, from 9:00 a.m. - 5:00 p.m.

- Jan. 9, 1989, in San Francisco, CA, at the Cathedral Hill Hotel, 1101 Van Ness Avenue, (415) 776-8200, from 9:00 a.m. - 5:00 p.m.

- Jan. 17, 1989, in Atlanta, GA, at the Westin Peachtree Plaza, Peachtree and International Boulevard, (404) 659-1400, from 9:00 a.m. - 5:00 p.m.

In another OCRWM management change, Franklin G. Peters has been appointed the program's Deputy Director, a position which also had been held by Mr. Kay. Mr. Peters has been with DOE for 12 years and was previously the Executive Assistant to the Deputy Secretary of Energy. Before his last assignment, he was special assistant (for Field Operations) to the Under Secretary. He has also held various management positions in DOE program and staff organizations and worked in the private sector as a management consultant. 论

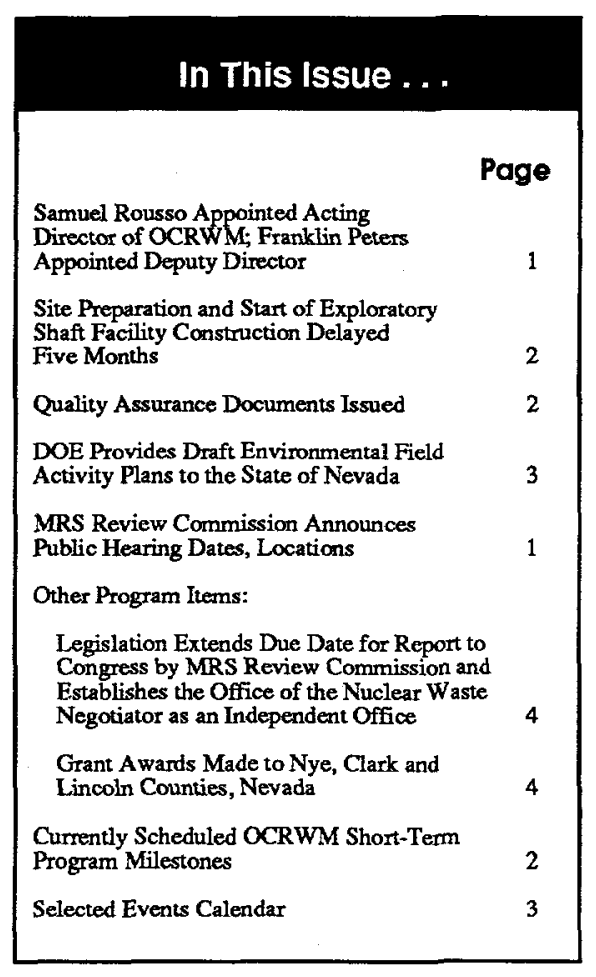

Published by the U.S. Department of Energy (DOE), Office of Civilian Radioactive Waste Management (OCRWM)

For further information about the national program or for copies of new publications and documents listed in the OCRWM Bulletin contact the U.S. Department of Energy, OCRWM, Office of External Relations and Policy, Mail Stop RW-40; 1000 Independence Avenue, SW, Washington, DC 20585, (202) 586-5722. The OCRWM Information Services Directory is available to provide sources of program information for the States, Indian Tribes, involved parties, and the public. 


\section{Site Preparation and Stant of Exploratory Shaff Facility Construction Delayed for Five Months}

The current schedule for activities related to the Yucca Mountain Project exploratory shaft facility (ESF) reflects a 5-month delay in the planned start of site preparation work necessary for construction of the ESF. Commencement of actual construction activities will be similarly affected and is now scheduled to begin in November 1989. The new schedule for major site characterization events is shown below:

- Issue Site Characterization Plan (SCP)

Dec. 1988

- Hold Public Briefings and Hearings on SCP in Nevada

Feb./Mar. 1989

- Begin Site Preparation Work

May 1989

- Begin Exploratory Shaft Construction

Nov. 1989

The delay in site preparation work and commencement of construction is to allow time for DOE to put into place prerequisite quality assurance procedures and design controls prior to start of final designs for the ESF.

DOE's planning and extensive interactions with the Nuclear Regulatory Commission (NRC) have allowed DOE to systematically define those prerequisites necessary for starting construction of the ESF. Among these prerequisites are:

- Development and implementation by DOE and acceptance by NRC of Yucca Mountain Project Quality Assurance Plans for ESF construction and testing.

- Development and implementation of comprehensive contractor design control procedures in developing final ESF designs.

With the additional time required to be ready to start site preparation, DOE is looking closely at the longer-term schedule to determine what impact this delay may have on the overall schedule. Surface-based testing described in the SCP is expected to begin in 1989 as soon as DOE has quality assurance plans in place and appropriate permits are received.

\section{Currently Scheduled OCRWM Short-Term Program Milestones}

Dec. 1988 Submit Yucca Mountain Site Characterization Plan to the Governor of Nevada, the Nuclear Regulatory Commission and the public.

Issue Yucca Mountain Socioeconomic Impact Report to Congress.

Issue Environmental Monitoring and Mitigation Plan.

Issue Revised Environmental Regulatory Compliance Plan.

Issue Environmental Program Overview.

Issue five Site Study Plans.

Jan. 1989 Submit Dry Cask Storage Study Report to Congress.

Mar. 1989 Issue Annual Report to Congress.

\section{Quality Assurance Documents Issued}

OCRWM is committed to have a fully qualified quality assurance (QA) program in place and accepted by the NRC prior to the start of new site characterization activities. Existing QA documents have been consolidated into the OCRWM Quality Assurance Requirements (QAR) Quality Assurance Program Description (QAPD) and the Nevada Nuclear Waste Storage Investigation Quality Assurance Plan (NNWSI 88-9). All three documents have been submitted to the NRC for acceptance.

\section{Quality Assurance \\ Requirements Document}

This document presents the QA requirements governing quality affecting activities of OCRWM, the Yucca Mountain Project Office and all other program participants. The requirements in the QAR establish a hierarchy flowing down from the OCRWM Director to the Associate Directors and the Project Manager to all program participants including contractors, other Federal agencies, national laboratories and ultimately to the individual scientist, engineer or technician performing the work.

The OCRWM QA program is applied to items and activities in a graded manner commensurate with their importance to safety, waste isolation or other program objectives. It incorporates and supplements the applicable QA program requirements from the Code of Federal Regulations, DOE Orders and ANSI/ ASME Standard NQA-1-1986 (Quality Assurance Program Requirements for Nuclear Facilities).*

(continued on page 4)

*NQA-1-1986, "Quality Assurance Program Requirements for Nuclear Facilities," a copyrighted publication of the American Society of Mechanical Engineers, contains an introduction, basic requirements

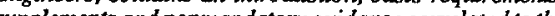
18. 18 criteria of Appendix $B$ of 10 Code of Federal Regulation 50. "Quality Assurance Criteria for Nuclear Power Plants and Fuel Reprocessing Plants," that establishes requirements for $Q A$ in the nuclear power industry. 


\section{DOE Provides Draft Environmental Field Activity Plans to the State of Nevada}

Environmental Field Activity Plans (EFAPs) describe the site-specific field and laboratory activities that will be conducted to support environmental site investigations at the candidate repository site at Yucca Mountain, NV. Draft EFAPs have been prepared and provided to the State of Nevada for the following environmental disciplines:

- Radiological Studies - establish the site-specific radiological background by collecting data necessary to (1) characterize the work environment at the site and evaluate the potential impact of past and future Nevada Test Site activities on the site, (2) support facility design and preparation of the safety analysis report, (3) monitor the impacts of site characterization on the environment, (4) verify the acceptability of specific analytical techniques for evaluation of environmental levels of selected radionuclides and provide data necessary for the decontamination and decommissioning of the site, as required and (5) demonstrate compliance with DOE, the Nuclear Regulatory Commission and Environmental Protection Agency environmental requirements.

- Air Quality - describe the ambient air quality monitoring program to (1) establish ambient particulate concentrations in the vicinity of Yucca Mountain and (2) determine impacts as needed for permitting.

- Terrestrial Ecosystems - (1) monitor and mitigate any potentially significant adverse impacts to terrestrial ecosystems caused by site characterization activities, (2) support radiological monitoring by providing samples and information on species used to monitor levels of radionuclides in the biotic environment and (3) provide basic information on the ecological parameters of native faunal associations that may be used to evaluate levels of impact to the environment. Floristic studies will be included in the EFAPs for reclamation feasibility studies.

- Cultural Resources: Native American Component - identify if, and to what extent, traditional cultural and religious values are associated with specific geographic areas within the project area. Additionally, if these values are found to be associated with geographic areas where land disturbing activities are proposed to occur, strategies to minimize the effects on traditional cultural and religious values will be developed in consultation with the Tribal Councils and key cultural experts from the Tribes.

- Cultural Resources: Archaeological Component - (1) identify all cultural resources in areas that may be affected by site characterization activities and evaluate all identified cultural resources, (2) evaluate potentially adverse effects to all significant cultural resources and (3) make recommendations for mitigating potential adverse impacts to affected cultural resources.

All of the draft EFAPs are written to implement the environmental data collection programs. In general, they provide (1) a description of the field activity to take place during site characterization, (2) a rationale for the studies proposed, (3) a description of field techniques and methods and the equipment and materials required and (4) quality assurance requirements.

In providing these draft EFAPs to the State of Nevada, DOE has offered to meet with the State to clarify the documents and exchange views over the proposed environmental field programs as described in the draft EFAPs.

\section{Selected Events Calendar}

Dec. $7-8$ Transportation Coordination Group Meeting, Kansas City, MO. Contact Beth Darrough (202) 586-5616.

Dec. 20

Briefing for NRC Commissioners at One White Flint North, Rockville, MD, by OCRWM Acting Director. Contact R. Stein (202) 586-6046.

Jan. 5,1989 MRS Review Commission Public Hearing, Stouffer Concourse Hotel, Denver, CO. Contact Paula N. Alford (202) 653-5616.

Jan. 9, 1989 MRS Review Commission Public Hearing, Cathedral Hill Hotel, San Francisco, CA. Contact Paula N. Alford (202) 653-5616. Jan. 17, 1989 MRS Review Commission Public Hearing, Westin Peachtree Plaza, Atlanta, GA. Contact Paula N. Alford (202) 653-5616.

For details on DOE/NRC meetings call (1/800) 368-2235 for a recorded message. In the Washington, DC, area call 479-0487.

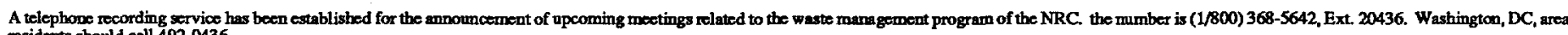
residemts should call $492-0436$.

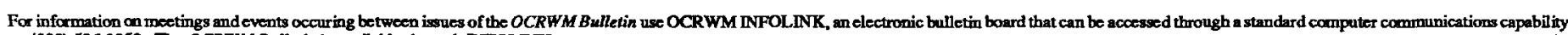
on (202) 586-9359. The OCRWM Bulletin is available through INFOLINK. 


\section{Other Program Items}

\section{Legislation Extends Due Date for Report to Congress by MRS Review Commission and Establishes the Office of the Nuclear Waste Negotiator as an Independent Office}

On Oct. 18, 1988, Public Law 100-507 was signed by the President. This Act extended the MRS Review Commission's Report due date regarding the need for an MRS facility from June 1,1989 to Nov. 1, 1989. The Report will address the need for an MRS facility as part of a national nuclear waste management system that achieves the purposes of the Nuclear Waste Policy Amendments Act of 1987 (Amendments Act). Because of the extension of the due date for the Report, the term of the MRS Review Commission has also been extended to Dec. 31, 1989.

Public Law 100-507 also mandated that the Office of the Nuclear Waste Negotiator, provided for in the Amendments Act, shall be an independent establishment in the executive branch outside of the Executive Office of the President.

\section{Grant Awards Made to Nye, Clark and Lincoln Counties, NV}

Pursuant to Section 116(c) of the Nuclear Waste Policy Act, as amended, DOE awarded an initial grant in the amount of $\$ 203,340$ to Nye County, NV, on Oct. 14, 1988. Similar grants were also awarded on Oct. 14,1988 , to Clark County for $\$ 313,568$ and to Lincoln County for $\$ 156,490$. The final grant awards will be made within the next several weeks. Section $116(\mathrm{c})$ provides authority for funding the following:

- Review activities of DOE, its participating contractors and related work of other participating Federal agencies with respect to the Yucca Mountain site for purposes of determining any potential economic, social, public health and safety and environmental impacts of a repository in Nye, Clark and Lincoln Counties and their residents.

- Develop a request for impact assistance designed to mitigate the impact of a nuclear waste repository and the characterization of the Yucca Mountain site.

- Engage in monitoring, testing, or evaluation activities with respect to site characterization programs at the Yucca Mountain site.

- Provide information to County residents regarding any activities of the County, the Secretary of Energy or the Nuclear Regulatory Commission with respect to the Yucca Mountain site.

- Request information from and make comments and recommendations to the Secretary of Energy regarding any activities with respect to the Yucca Mountain site and nuclear waste repository issues.

\section{Qualify Assurance Documents Issued (continued from page 2)}

The QAR consists of 18 sections structured in accordance with NQA-1 that address such topics as QA management; QA program elements; design, procurement and document control; inspection; control of tests, processes and measuring and test equipment; handling, storage and shipping; corrective action; and QA records and audits.

\section{Quality Assurance Program Description Document}

This document consists of 18 sections covering the same topics as the QAR and:

- describes how OCRWM will implement the QA requirements in the QAR;

- describes organizational responsibilities for achieving and assuring quality at OCRWM and

- describes the interfaces between OCRWM and the Yucca Mountain Project Office for achieving and assuring quality.

Nevada Nuclear Waste Storage Investigation Quality Assurance Plan

The NNWSI 88-9 document serves as the framework for the Project Office and its participants to develop specific policies, plans and procedures to implement the QA program for the Yucca Mountain Project. This document is based on the QA program requirements specified in the OCRWM QAR document. The NNWSI 88-9 document also addresses all 18 criteria in accor dance with NQA-1 and presents requirements that must be met by all participants.

In addition to development of the documents described above, required program-wide indoctrination and training of OCRWM and contractor employees (continued on page 5) 


\section{Quality Assurance Documents Issued}

(continued from page 4)

has been initiated to ensure an understanding and recognition of individual responsibilities in meeting program quality and performance objectives. This includes an awareness of QA needs and benefits and the NQA-11986 basic criteria under which QA programs have been established and used successfully throughout the U.S. nuclear power industry.

The responsibility for the integrity and technical quality of all work performed is with the line management and technical staff performing the work. The role of the QA staff is to verify the work performed independent of those performing the technical work. Readiness reviews, surveillances, inspections and audits (with observation by the NRC and the State of Nevada) will be conducted to verify that the program is functioning according to program requirements and plans. 
Do $110 T$

MI

THS 


\section{OCRWM Bulletin}

Office of Civilian Radioactive Waste Manugement Washington, DC 20585

\section{Site Characterization of the Vucca Mountain Site in Nevada}

In December 1987 the Yucca Mountain site in Nevada was designated by the Nuclear Waste Policy Amendments Act of 1987 (Amendments Act) for detailed study as the candidate site for the first U.S. geologic repository for spent nuclear fuel and high-level radioactive waste. A comprehensive program of detailed investigations called "site characterization" will be conducted by DOE at Yucca Mountain to determine whether it is suitable for a repository. If the site is suitable, then DOE must demonstrate to the Nuclear Regulatory Commission (NRC) that the site meets regulations intended to protect the health and safety of the public both during repository operations and after the repository has been permanently closed. In order to demonstrate to the NRC that the repository system - that is, the site, the repository and the waste package - will perform as required, DOE must also develop designs for the repository and the waste package and conduct scientific assessments to determine that the performance of the repository system will meet all applicable regulations.

This comprehensive program is described in a document known as the Site Characterization Plan (SCP) for the Yucca Mountain site. The SCP is a ninevolume document, approximately 6,300 pages in length, that describes in (continued on page 2)

\section{Why and How the Site Characterization Plan Was Developed}

Legislative and Regulatory

Requirements for the SCP Process

Requirements for the licensing of geologic repositories were issued by the NRC in 10 Code of Federal Regulations Part 60. The NRC regulations implement and enforce the environmental standards issued for the management and disposal of radioactive waste by the Environmental Protection Agency (EPA) in 40 Code of Federal Regulations Part 191. Both the NRC and EPA regulations were issued in response to the requirements of Section 121 of the Nuclear Waste Policy Act of 1982 (NWPA). A site characterization program that will provide the information needed to address these requirements is mandated by Section 113 of the NWPA.
The NWPA, as recently amended, also specifies that, before starting to construct exploratory shafts at Yucca Mountain, DOE must meet the following requirements:

- Submit to the NRC, as well as to the Governor and Legislature of the State of Nevada, a Site Characterization Plan for their review and comment and

- Make the SCP available to the public and hold public hearings to inform the residents of the Yucca Mountain area of the SCP and to receive their comments.

To meet these requirements, DOE has submitted copies of the SCP to the NRC (continued on page 3 )

\section{In This Issue}

Site Characterization of the Yucca

Mountain Site in Nevada

Why and How the Site Characterization Plan Was Developed

The Site Characterization Plan Overview

How to Leam More About the Site

Characterization Plan

What Happens After Site

Characterixation?

DOE Issues Report on Mitigation of

Potential Impacts of Locating a

Repository at the Yucca Mountain Site

DOE Issues Draft Environmental

Program Overview for Yucca

Mountain Site

Currently Scheduled OCRWM

Short-Term Program Milestones

Selected Events Calendar

New Publications and Documents
Page

1

1

5

3

2

7

6

6

8

7

Published by the U.S. Department of Energy (DOE), Office of Civilian Radioactive Waste Management (OCRWM)

For further information about the national program or for copies of new publications and documents listed in the OCRWM Bulletin contact the U.S. Department of Energy, OCRWM, Office of External Relations and Policy, Mail Stop RW-40, 1000 Independence Avenue, SW, Washington, DC 20585, (202) 586-5722. The OCRWM Information Services Directory is available to provide sources of program information for the States, Indian Tribes, involved parties, and the public. 


\section{What Happens After Site Characterization?}

The Nuclear Waste Policy Act, as amended, specifies other steps in the process for siting and licensing a repository in addition to its requirements for site characterization.

At any point in the site characterization process, DOE could uncover a major disqualifying flaw at the Yucca Mountain site. The discovery and confirmation of such a flaw would bring site characterization activities to a halt. Similarly, at the end of the site characterization process, DOE could conclude that the site is unsuitable. In either case, if the Yucca Mountain site is determined to be unsuitable for a repository, then DOE must stop all site characterization activities at the site and take reasonable and necessary steps to reclaim the site and to mitigate any significant adverse environmental impacts caused by site characterization activities. Also, DOE must notify Congress and the Governor and Legislature of Nevada of the termination and recommend further action to the Congress to provide for the permanent disposal of the waste. This recommendation for further action is to be made not later than 6 months after the determination of unsuitability.

If after site characterization the site is found to be suitable, the Secretary of Energy will submit a report to the President to recommend Yucca Mountain for development as a repository. This report will be accompanied by an environmental impact statement. If the President approves, the recommendation will go to Congress.

Within 60 days after Congress has received this recommendation, the State of Nevada may submit a notice of disapproval to Congress. This will prevent the development of the site as a repository unless Congress passes a joint resolution of repository siting approval within the next 90 days of continuous session. If no

(continued on page 6)

\section{Site Characterization of the Yucca Mountain Site in Nevada \\ (continued from page 1 )}

considerable detail, the activities that will be conducted to characterize the geologic, hydrologic and other conditions relevant to the suitability of the site for a repository (see Figure 1).

The contents of the SCP and its level of detail reflect earlier consultations with the staff of the NRC and the State of Nevada. The SCP presents general information on the sequence of activities, the priorities assigned to the activities and general schedules for the site characterization program. The detailed descriptions of site characterization studies and activities will be given in study plans. Not included in the SCP are the activities that will be performed to collect data on environmental and socioeconomic conditions. Plans for these activities are described in other documents (see page 8).

Figure 1. Organization of the SCP

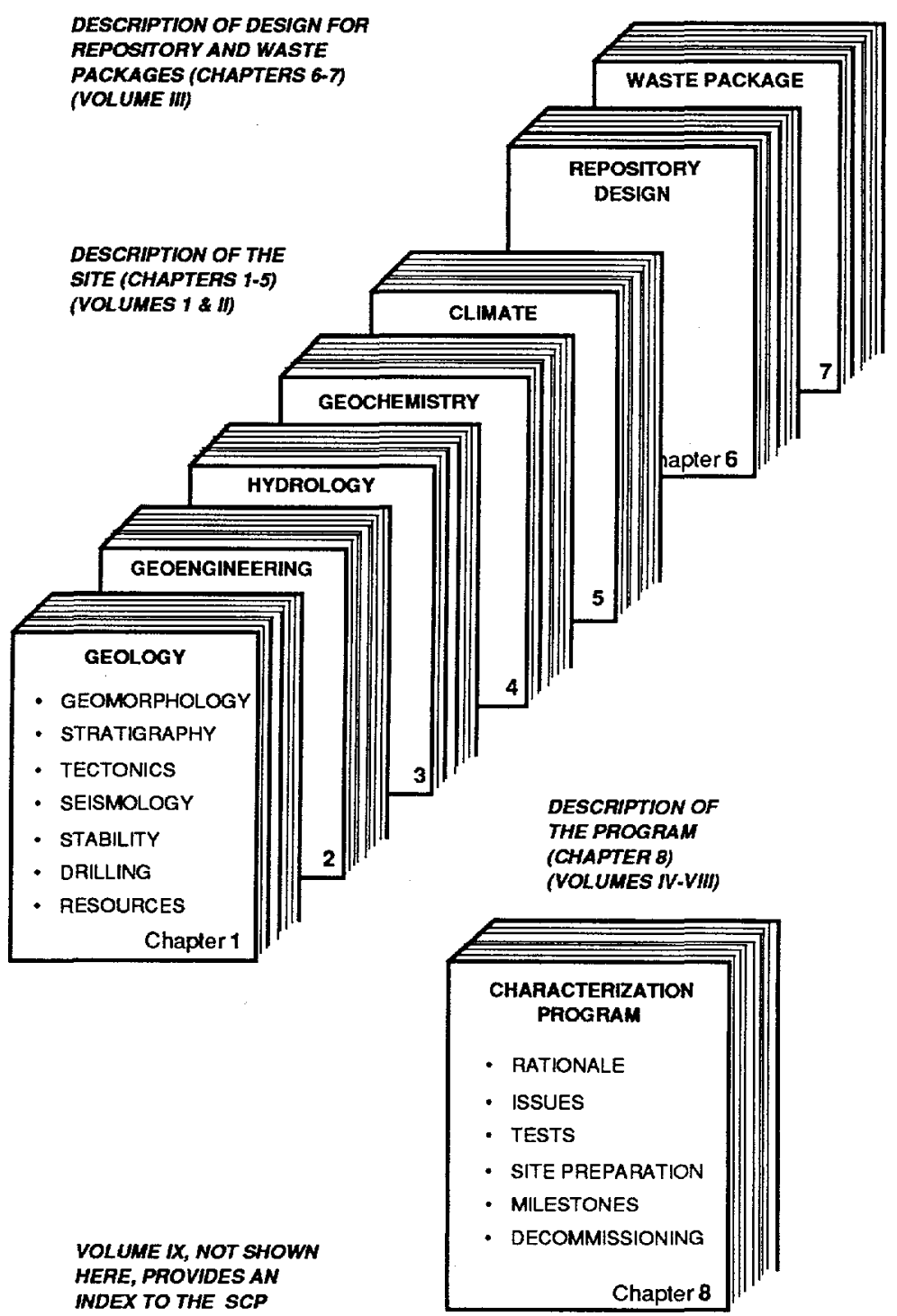




\section{Why and How the Site Characterization Plan Was Developed \\ (continued from page 1)}

and to the Governor and the legislature of Nevada. In addition, DOE has submitted the SCP to the affected units of local government in Nye, Clark and Lincoln Counties, Nevada.

To ensure that the SCP is available to the public, DOE has placed copies of the SCP in the public reading rooms of its Operations Offices around the country and in public libraries in Nevada (see below and page 4).

To help the public understand the SCP and the site characterization program, DOE has prepared an Overview and a Public Handbook that are described in this Bulletin (see below and page 5).

\section{The Consultation Draft of the SCP}

On Jan. 8, 1988, DOE issued a consultation draft of the SCP (CD/SCP) for the Yucca Mountain site to the State of Nevada and the NRC. The purpose of the CD/SCP was to provide an advance forum for DOE to explain the organization and content of the SCP and to consult with the State of Nevada and the NRC staff on concerns they may have and, if possible, to resolve these concerns.

Preliminary comments on the consultation draft were submitted to $D O E$ by the NRC staff in March 1988, and final comments were submitted in May 1988. In addition, comments were received from the U.S. Geological Survey in April 1988 and from the Edison Electric
Institute and the Utility Nuclear Waste Management Group in August 1988. The State of Nevada submitted comments in September 1988.

The SCP, as issued, represents a significant revision of the CD/SCP and reflects the comments received before the end of the comment period designated for the consultation process (June 1988). During the consultation period, DOE held several technical meetings and workshops with the NRC and the State of Nevada. Comments received after the close of the comment period will be considered; and if any changes are made in the site characterization program as a result of these comments, these changes will be in semi-annual Progress Reports.

\section{How To Learn More About the Site Characterization Plan}

A Public Handbook has been prepared to serve as a guide to help interested citizens understand, locate and use information contained in the Site Characterization Plan (SCP). Part 1 of the Handbook explains what site characterization is and how the SCP relates to it. Part 2 tells how to locate subjects covered by the plan. In addition, the Handbook identifies opportunities for public involvement in the review of the SCP.

Copies of the SCP have been distributed directly to a number of interested Federal, State and local agencies. The SCP is also available for public inspection at the following DOE Public Reading Rooms:

Albuquerque Operations Office

Pennsylvania \& $\mathrm{H}$ Sts.

Kirkland Air Force Base

Albuquerque, NM 87115

Chicago Operations Office

9800 South Cass Avenue

Argonne, IL 60439

Idaho Operations Office

Technical Library

785 DOE Place

Idaho Falls, ID 83402
Nevada Operations Office

Technical Library

2753 South Highland Drive

Las Vegas, NV 89193-8518

Oak Ridge Operations Office 200 Administration Road

Oak Ridge, TN 37830

Richland Operations Office

825 Jadwin Avenue

Richland, WA 99352
San Francisco Operations Office

1333 Broadway

Oakland, CA 94612

Savannah River Operations Office University of South Carolina-Aiken Gregg-Graniteville Library

171 Parkway

Aiken, SC 29801

DOE Public Reading Room

1000 Independence Avenue, S.W.

Room 1E-190

Washington, DC 20585

(continued on page 4) 


\section{How To Learn More About the Site Characterization Plan \\ (continued from 3)}

In addition to DOE's reading rooms, the SCP will be available for public inspection at the DOE Yucca Mountain Information Office in Beatty, NV, at U.S. Route 95 and State Route 374 and at the following locations in Nevada.

Amargosa Valley Community Center HCR 69-2, Box 401-T Amargosa Valley, NV 89020

Beatty Community Library

Fourth and Ward Street

Beatty, NV 89003

Clark County Library 1401 E. Flamingo Road

Las Vegas, NV 89119

\author{
Nevada State Library \\ 401 N. Carson Street \\ Carson City, NV 89710 \\ Tonopah Public Library \\ 171 Central \\ Tonopah, NV 89049
}

University of Nevada, Reno
Getchell Library
Reno, NV 89557-0044

Washoe County Library

301 S. Center

Reno, NV 89501

University of Nevada, Las Vegas

James R. Dickinson Library

4505 Maryland Parkway

Las Vegas, NV 89154

Public involvement is encouraged through the review and comment period that will occur for 90 days after the SCP is issued. All comments received during this period will be considered and made part of the official record for the SCP. Any changes in the site characterization program SCP as a result of these comments will be noted in future Progress Reports that will be issued in 6-month intervals. Copies of these reports will be available in local libraries and the Yucca Mountain Information Office in Beatty, Nevada.

During February 1989, Project Update Meetings will be conducted in Nevada by the DOE Yucca Mountain Project Office to inform interested parties of DOE's planned activities and the site characterization process. These meetings will be widely advertised. Those persons whose names are on repository program mailing lists will be notified, and meeting information will be provided to the news media. The public is invited to attend these meetings and review the SCP. DOE plans to continue to hold Yucca Mountain Project Update Meetings in the future to keep the public informed about site characterization.

Currently scheduled meetings will be held at the following locations in Nevada from 7:00 p.m to 10:00 p.m. on the dates indicated.

February 15 in Beatty, at the Beatty Community Center

February 16 in Las Vegas, at the Aladdin Hotel

February 21 in Caliente, at the Caliente Girls Training Center

February 23 in Reno, at the Reno-Sparks Convention Center

About one month after the Update Meetings, public comments will be solicited through Public Hearings that will be held at the following locations in Nevada from 2:00 p.m. to 5:00 p.m. and from 7:00 p.m. to 10:00 p.m. on the dates indicated.

March 20 at the Amargosa Valley Community Center

March 21 at the Aladdin Hotel in Las Vegas

March 23 at the Reno Hilton Hotel

In addition to public hearings and briefings, written comments on the SCP may be submitted to: SCP Comments, Yucca Mountain Project Office, U.S. Department of Energy, P.O. Box 98518, Las Vegas, NV 89193. 


\section{The Site Characterization Plan Overview}

The Overview of the Site Characterization Plan (SCP) presents summaries of selected topics covered in the SCP. It is intended primarily for those persons who want to understand the general scope and basis of the site characterization program, the activities to be conducted and the facilities to be constructed without spending the time necessary to become familiar with all of the technical details presented in the SCP. The Overview will be useful as a general guide to the readers of the SCP.

The basic purpose of the SCP is to:

- Describe the site, the preliminary designs of the repository and the waste package and the waste emplacement environment in sufficient detail so that the basis for the site characterization program can be understood,

- Identify the issues (questions related to the performance of the repository system) that must be resolved during site characterization, including the issues related to site suitability; to present the strategy for resolving the issues; and identify the information needed to resolve the issues, and

- Describe the general plans for the work needed to obtain the information deemed necessary and to resolve outstanding issues.
The SCP Overview is structured somewhat differently from the SCP itself. An introduction presents general information on site characterization, the SCP and the siting process after site characterization. Chapter 2 briefly describes the Yucca Mountain site, including a history of the process by

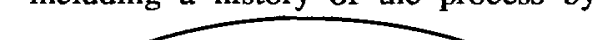

Chapter 4 of the Overview discusses the various activities that will be conducted at the Yucca Mountain site during characterization and describes the facilities that will be constructed for that purpose. It also discusses the analyses that have been conducted to determine that the activities conducted during site characterization will not significantly affect the ability of the site to provide waste isolation.

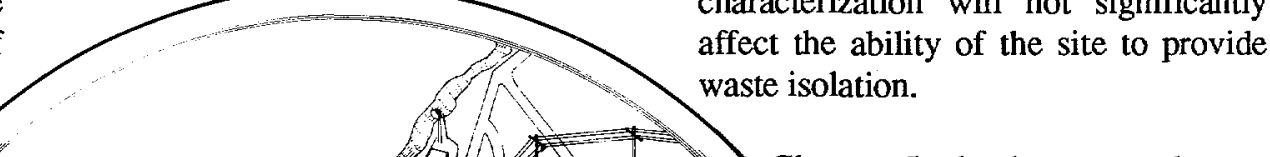

Chapter 5, the longest and most detailed of the Overview chapters, explains the basis for the site characterization program. It begins by discussing the top level strategy for determining whether a repository would perform satisfactorily at Yucca Mountain. Next it discusses the hierarchy of issues that must be addressed by the site characterization program and summarizes DOE's Fault preliminary strategies for the to obtain the information needed support these strategies as well as the programs in which this information will be used. These include (1) refining the

which the site was selected for characterization and the characteristics that are pertinent to a geologic repository, as determined by investigations performed to date. Chapter 3 presents information about preliminary designs for the repository and the containers in which waste would be packaged for disposal. designs of the repository, the system to seal the repository and the waste package and (2) assessing the performance of the repository. Chapter 5 is followed by a glossary. Included in the Overview is an appendix that presents the issues and information needs for the Yucca Mountain site. 


\section{DOE Issues Draft Environmental Program Overview For Yucca Mountain Site}

DOE is committed to performing its activities in an environmentally safe and sound manner, and will comply with applicable environmental statutes and regulations. The environmental program is integrated with other OCRWM programs to evaluate the Yucca Mountain site as a candidate site for a repository.

Figure 2 on page 9 illustrates the organization of the environmental program together with the major components of the environmental program. Each of these components are described in the draft Environmental Program Overview (EPO) which was released in December 1988. The environmental planning documents provide the breakdown, requirements and descriptions of activities to be performed, including necessary reports, in order to accomplish the program. Programmatic planning documents include:

- Environmental Monitoring and Mitigation Plan (EMMP) to plan how DOE will conduct environmental monitoring and implement mitigation for site characterization activities identified as having the potential for causing significant adverse environmental impacts.

- Environmental Regulatory Compliance Plan (ERCP) to plan how DOE will address regulatory compliance for site characterization.

- Reclamation Program and Implementation Plans (RPP, RIP) to plan and implement reclamation at the Yucca Mountain site. The RIP will be responsive to the policy specified in the Reclamation Program Plan.

- Environmental Impact Statement (EIS) Implementation Plan to record the results of the scoping process, to plan what technical information is required to complete the EIS and to plan how DOE will manage and produce the EIS.

Also identified in Figure 2 on page 9 are the final tier of planning documents - the Environmental Field Activity Plans (EFAPs) and the Reclamation Feasibility Plan (RFP). The EFAPs (described in the October/November 1988 OCRWM Bulletin) and the RFP are integrated technical plans that describe the discipline-specific field activities necessary to satisfy data collection requirements of each of the above environmental planning documents. The EFAPs will be modified over time to meet all Project environmental requirements. Thus, in the current site characterization phase, the EFAPs describe the field activities necessary to meet the EMMP and ERCP environmental data requirements. Future requirements, such as those associated with the Environmental Impact Statement, will later be added to the EFAPs.

\section{What Happens After Site Characterization? \\ (continued from page 2)}

notice of disapproval is submitted or if a notice of disapproval is overturned by a joint resolution, then the site designation will become effective. At that time, the Secretary will submit an application to the NRC within 90 days for authorization to construct the repository.

This application will contain a description of the site, a description of the repository and the waste package and the results of the assessments performed to demonstrate that the repository complies with the applicable regulations. The NRC will review the application and decide whether to authorize the construction of the repository. If NRC authorization is received, construction may begin.

When the repository is ready for operation, DOE will submit an updated license application to the NRC seeking a license to receive and possess waste at the site. If this is granted, DOE can begin repository operations.

At the end of repository operations, DOE must submit an application to the NRC seeking an amendment to the license permitting DOE to permanently close the repository. If this amendment is granted, DOE can close and seal the repository. Once closure has been completed, DOE must then submit an application to the NRC for an amendment to terminate the license and decommission the surface facilities.

\section{Currently Scheduled OCRWM Short-Term Program Milestones}

Dec. 1988

Submit Yucca Mountain Site Characterization Plan to the Governor and Legislature of Nevada, affected units of local government in Nevada, the Nuclear Regulatory Commission and the public.

Submit Yucca Mountain Socioeconomic Impact Report to Congress.

Issue Revision 2, Environmental Monitoring and Mitigation Plan.

Issue Revision 1, of Environmental Regulatory Compliance Plan.

Issue draft Environmental Program Overview.

Issue 5 exploratory shaft construction-phase Site Study Plans.

Jan. 1989

Submit Dry Cask Storage Study Report to Congress.

Mar. 1989 Submit Annual Report to Congress. 


\section{DOE Issues Report on Mitigation of Potential Impacts of Locating A Repository at the Yucca Mountain Site}

Section 175 (a) of the Nuclear Waste Policy Act of 1982, as amended, directs the Secretary of Energy to report the following to Congress by December 1988 :

"... the potential impacts of locating a repository at the Yucca Mountain site, including the recommendations of the Secretary for mitigation of such impacts and a statement of which impacts should be dealt with by the Federal Government, which should be dealt with by the State with State resources, including the benefit payments under Section 171 , and which should be a joint Federal/State responsibility. The report under this subsection shall include the analysis of the Secretary of the authorities available to mitigate these impacts and the appropriate sources of funds for such mitigation."

Based on the identification of effects that may occur in Nevada as a result of the repository program as well as an analysis of the authorities available to the Secretary and appropriate sources of funds for possible mitigation activities, the Secretary has concluded that DOE has the necessary authorities and sources of funds to be administered in close consultation with the State and affected units of local government to address impacts that may occur throughout the course of the program.

The report also concludes that:

- Program-related effects might occur in at least 12 categories specified in the Amendments Act.

- Because of the uncertainties inherent in projecting worker settlement patterns, four different residential location scenarios were evaluated. The scenarios were used in this report as a basis for identifying a range of potential effects. No one of these four scenarios is viewed as more likely than the others. The same categories are identified as potentially affected under each scenario, although the location and magnitude of the effects vary with each scenario.

- The primary goal of DOE's policy for mitigation is to conduct its activities in a manner that would avoid or minimize significant adverse impacts to the maximum extent practicable.

- An important element in mitigation will be the implementation of a monitoring program to determine whether impacts have been avoided, whether mitigation has been effective in reducing impacts and whether new impacts have emerged. This monitoring program will be described in the Socioeconomic Monitoring and Mitigation Plan for Site Characterization. The conduct of the monitoring program and the collection of data will be closely coordinated with the State and affected units of local government.

- Initial evaluation of need and appropriate mitigation should be made by the communities experiencing impacts. To the extent that these evaluations show the need for assistance,
DOE will work closely with the State or affected unit of local government to reach agreement on the nature and level of such assistance.

- Impacts related to the transportation of radioactive waste and accident management will depend on the programmatic decisions concerning waste transport and emergency response capabilities.

- Initial efforts at addressing changes in demand for facilities and services resulting from repository activities should focus on minimization or avoidance through modifications to DOE activities and also accommodation by the jurisdiction through the use of available resources, including additional revenues generated by the repository program, such as PaymentsEqual-to-Taxes. Financial assistance for mitigation can be provided by DOE through a negotiated agreement under authority granted by Congress in the Amendments Act. Mitigation to address adverse impacts should be administered by the jurisdictions and entities that customarily provide facilities or services.

\section{New Publications And Documents}

\section{Site Characterization Plan Overview: Yucca Mountain Site, Nevada Research and Development Area, Nevada, DOE/RW-0198, December 1988.*}

This document presents summaries of selected topics covered in the Site Characterization Plan (see page 5 for a more complete description of the Overview).

\section{Site Characterization Plan for the Yucca Mountain Site, State of Nevada, DOE/RW-0199, December 1988.*}

The Site Characterization Plan is a large document, approximately 6,300 pages in length, and includes a description of the candidate site, a description of planned site characterization tests and activities, plans for decontamination and decommissioning should the site not be found suitable for development as a repository and criteria to be used to determine suitability. The Site Characterization Plan also describes the conceptual design for a repository at the site and the possible packaging for the high-level radioactive waste and spent nuclear fuel to be emplaced in such a repository.

$$
\text { (continued on page 8) }
$$




\section{New Publications And Documents \\ (continued from page 7$)$}

Secretary of Energy Report to the Congress Pursuant to Section 175 of the Nuclear Waste Policy Act, as Amended, DOE/RW-0205, December 1988.**

In accordance with Congressional requirements, this report addresses the potential impacts of locating a repository at the Yucca Mountain site as well as recommendations for mitigation of such impacts and the appropriate sources of funds for such mitigation (see page 7 for a more detailed description of the Section 175 report).

Site Characterization Plan Public Handbook for Yucca Mountain, DOE/ RW-0206, January 1989.*

This Handbook explains what site characterization is, how the Site Characterization Plan relates to it and how to locate subjects covered in the SCP.
It also identifies opportunities for public involvement in the review of the Site Characterization Plan (see page 3 for a fuller description of the Handbook).

\section{Draft Environmental Program Overview, DOE/RW-0207, December 1988.**}

The draft Environmental Program Overview presents the environmental requirements applicable to the program, describes the methodology to be used to ensure that these requirements will be satisfied and details the products or documents to be developed in the process of satisfying those requirements (see page 6 for further description of the draft Environmental Program Overview).

Environmental Monitoring and Mitigation Plan for Site Characterization, Revision 2, DOE/RW-0208, December 1988.**
This plan describes DOE's monitoring and mitigation programs for site characterization and focuses only on site characterization activities with a potential for causing significant adverse environmental impacts.

* Copies of these publications are available upon request to the U.S. Department of Energy, Yucca Mountain Project Office, P.O. Box 98518, Las Vegas, NV 89193, or to the U.S. Department of Energy, Office of Civilian Radioactive Waste Management (RW43), 1000 Independence Avenue, S.W., Washington, DC 20585.

** Copies of these reports are available upon request from U.S. Department of Energy, Office of Scientific and Technical Information, P.O. Box 62, Oak Ridge, TN 37831.

\section{Selected Events Calendar}

Jan. 5, 1989 MRS Review Commission Public Hearing, Stouffer Concourse Hotel, Denver, CO. Contact Paula N. Alford (202) 653-5616.

Jan. 9 MRS Review Commission Public Hearing, Cathedral Hill Hotel, San Francisco, CA. Contact Paula N. Alford (202) $653-5616$.

Jan. 17 MRS Review Commission Public Hearing, Westin Peachtree Plaza, Atlanta GA. Contact Paula N. Alford (202) 653-5616.

Feb.15 Yucca Mountain Project Update Meeting, 7:00-10:00 p.m., Beatty Community Center, Beatty, NV.*

Feb. 16 Yucca Mountain Project Update Meeting, 7:00-10:00 p.m., Aladdin Hotel, Las Vegas, NV.*

Feb. 21 Yucca Mountain Project Update Meeting, 7:00-10:00 p.m., Caliente Girls Training Center, Caliente, NV.*

Feb. 23 Yucca Mountain Project Update Meeting, 7:00-10:00 p.m., Reno-Sparks Convention Center, Reno, NV.*

Mar. 20 Site Characterization Plan Public Hearing, 2:00-5:00 p.m. and 7:00-10:00 p.m.,

Amargosa Valley Community Center, Amargosa, NV.*

Mar. 21 Site Characterization Plan Public Hearing, 2:00-5:00 p.m. and 7:00-10:00 p.m., Aladdin Hotel, Las Vegas, NV.*

Mar. 23 Site Characterization Plan Public Hearing, 2:00-5:00 p.m. and 7:00-10:00 p.m., Reno Hilton Hotel, Reno, NV.*

* For further information contact Yucca Mountain Information Office, U.S. Department of Energy, (702) 553-2130 or Office of External Affairs, Nevada Operations Office, (702) 295-3521.

For details on DOE/NRC meetings call (1/800) 368-2235 for a recorded message. In the Washington, DC, area call 479-0487.

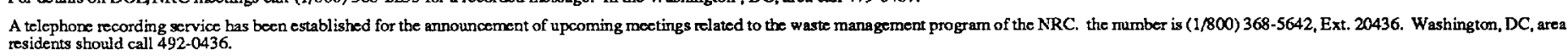

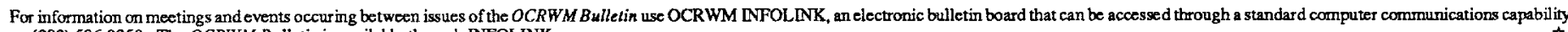
on (202) 586-9359. The OCRWM Bulletin is available through NFOLINK. 
Figure 2. Environmental Planning Process and Documents

Define the

System

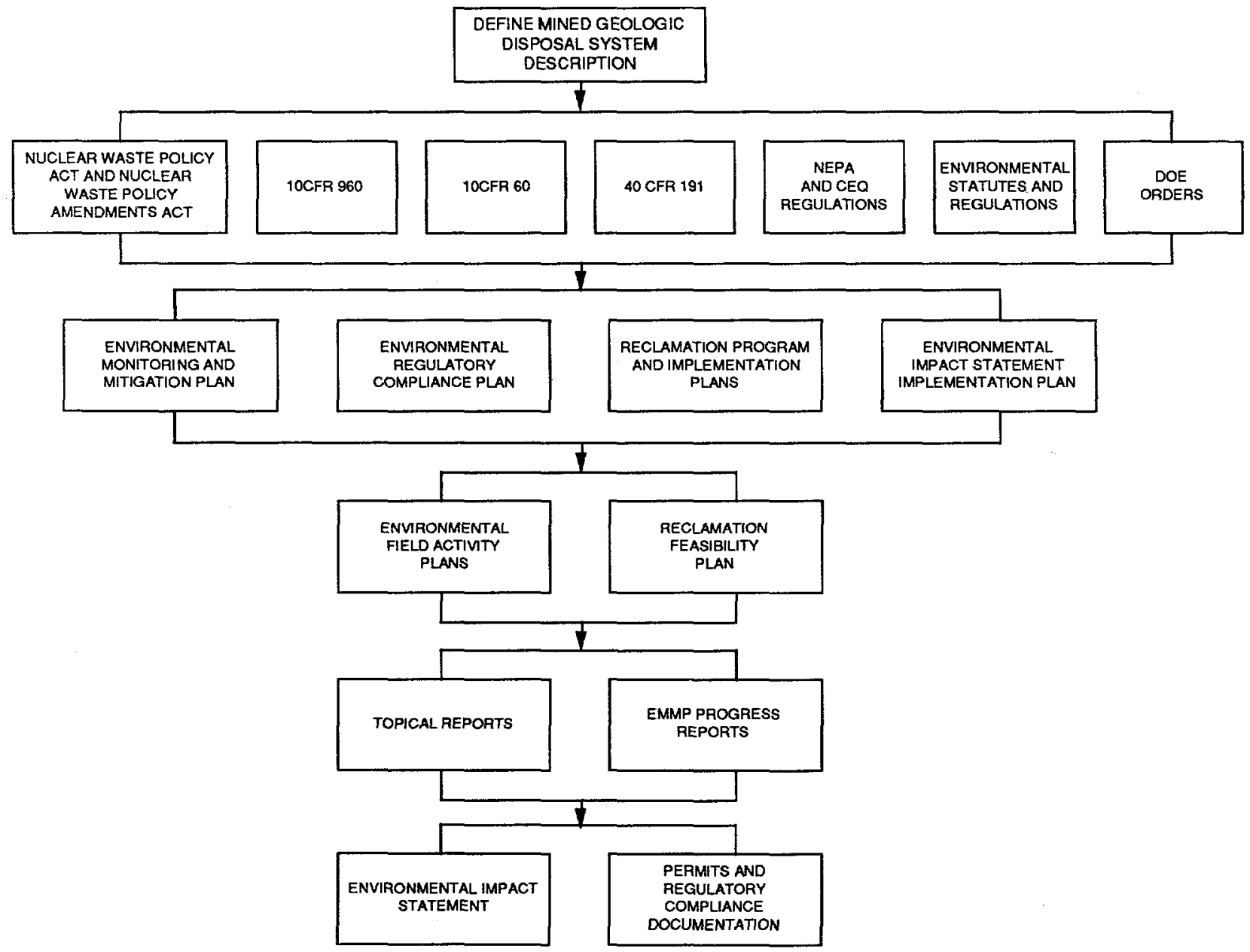

Satisfaction of

Environmental

Requirements 


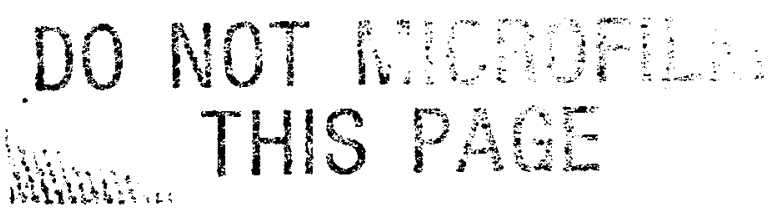




\section{OCRWM Bulletin}

United States Department of Energy

Office of Civilian Radioactive Waste Management

Washington, $D C 20585$

Index
Advisory Committee on Nuclear Waste, 24

Affected unit of local government, 24

Agencies

International Atomic Energy, 15

Nuclear Energy Agency of the Organization for

Economic Cooperation and Development, 15

Amendments Act (see Nuclear Waste Policy

Amendments Act of 1987)

American Association of State Highway and

Transportation Officials (AASHTO), 45, 47

American Nuclear Society, 34

ANSI/ASME Standard NQA-1-1986, 50

Appointments

MRS Commission

Dr. Dale E. Klein, 35

Dr. Frank L. Parker, 35

Alex Radin, 35

Office of Civilian Radioactive Waste Management

Acting Director, C. E. Kay 19, 49

Acting Director, S. Rousso, 49

Deputy Director, F. Peters, 49

Office of External Relations and Policy

Associate Director, T. Isaacs, 19

Deputy Associate Director, L. Barrett, 19, 42

Office of Facilities Siting and Development

Associate Director, S. Kale, 19

Deputy Associate Director, J. Saltzman, 19

Office of Program Administration and Resource

Management

Associate Director, S. Rousso, 19

Deputy Associate Director, J. Bresee, 19

Office of Quality Assurance

Acting Director, P. Saget, 19

Director, L. Barrett, 42, 49
Office of Systems Integration and Regulations

Associate Director, R. Stein, 19

Deputy Associate Director, K. Klein, 19

Babcock and Wilcox, 38

Battelle Columbus Division, 3

Benefits Agreement, 2, 15, 24, 29, 52 (see also Funding)

Budget (see Funding)

Bureau of Land Management (BLM), 7-8

Carolina Power and Light, 17

Casks (see Storage, dry cask and Transportation Program)

Citizens Alert, 17

Clark County, Nevada, 24, 52, 59

Closeout activities, 8, 15, 21

Code of Federal Regulations

10 CFR 1,11

10 CFR 51,46

10 CFR 53, 11

10 CFR $60,27,32,55$

10 CFR 61,46

10 CFR $600.123,8$

10 CFR 961, 36

10 CFR 191, 55

Commercial Vehicle Safety Alliance (CVSA), 33

Coordination Groups, 8

Transportation, 4, 23, 25, 41

Quality Assurance, 35 
Consultation and cooperation, 24, 29

Consultations, DOE/NRC, 27-28, 40, 42, 50

Cooperative demonstrations, 17

Deaf Smith County, Texas, 14, 18

Department of the Interior, 7

Draft Mission Plan Amendment, 31, 35, 44

Edison Electric Institute, 57

Emergency response, 25, 26

Environmental protection

Environmental Field Activity Plans, 51, 60

environmental planning process and documents, 60 , table 63

Environmental Program Overview (draft), 60 figure 63

environmental site investigations, 51

(see also Research and Development, Reports)

Exploratory Shaft Facility, 1, 44

construction delay, 50

Federal Highway Administration, 45, 47

Federal Interim Storage, 11, 12, 25-26

Federal Register Notices, 24, 40, 42

Financial assistance, 15, 29

\section{Funding}

assistance for training, 26

Benefits Agreement, 15, 24

grant awards, 52

provision for payments, 29

siting benefits, 2

Civilian Radioactive Waste Research and

Development Program, 17

Congressional appropriations, 43

Dry Cask Storage Program, 16, 20

NRC Memorandum of Understanding, 17, 37-38

monitored retrievable storage, 16

OCRWM budget, 13-17, tables 9, 13, 14
NRC fees, 16

Nuclear Waste Fund, 13-17, 20, 43, tables 17, 43 goals, 14

pre-licensing activities, 39

project closeouts, 8

cessation of grants, 8

transportation, 16

General Accounting Office, 3

General Atomics, 25, 38

Glass waste forms, 3

Governor Richard H. Bryan, Nevada, 24, 29

Grants-Equal-to-Taxes, 2

Hanford, Washington, 1, 8, 14

Inspector General Audit, 4

International Bridge, Tunnel, and Turnpike Association (IBTTA), 45, 47

International Cooperative Activities, 15

Lawrence Livermore National Laboratory, 32

Legislation

(see Nuclear Waste Policy Act, Nuclear Waste

Policy Amendments Act, and Public Laws)

Licensing

Licensing Support System, 3, 16, 28

selection of contractor, 3

proposed NRC rule, 39

Lincoln County, Nevada, 52

Los Alamos National Laboratory, 32

Management and Operating Contract, 19, 20, 27

Memorandum of Understanding NRC, 37-38

Mission Plan Amendment, 9 (see also Draft Mission Plan Amendment) 
Mitigation, 61

Monitored Retrievable Storage additional information on MRS Report, 3 authorization, 1-2

discussion, 16

funding, 16

public participation, 16,49

Report to Congress, 52

Review Commission Schedule, 2, 10, 16, 35, 49

members named, 35

testing and demonstration, 16

Monitoring and Mitigation

DOE capabilities and policy, 61

Environmental Monitoring and Mitigation Plan, 15,60

planning document, 60

National Conference of State Legislatures

(NCSL), 25

National Congress of American Indians (NCAI), 25

National Environmental Policy Act, 1, 8, 46

Negotiatior, 2, 10, 52

Nevada Nuclear Waste Site Investigations, 38

Nevada Nuclear Waste Project Office, 18

Nevada Nuclear Waste Study Committee, 17

Nevada Waste Management Project Office, 17, 32,38

Northeast Utilities Services Co., 17

Nuclear Assurance Corp., 25, 38

Nuclear Fuel Data Form RW-859 (1987), 36

Nuclear Packaging, Inc., 38

Nuclear Regulatory Commission (NRC), 15, 17, 18

Advisory Committee on Nuclear Waste, 24 alternative conceptual models for repository site, $18,27,28$

eligibility of Federal Interim Storage applicants, 11

High-Level Waste Advisory Committee on the Licensing Support System, 39

interactions on exploratory shaft facility, 50

Memorandum of Understanding, 17, 37

pre-licensing funding activities, 17, 37

prenotification regulations, 26

proposed rule for licensing and records

management, 39

reports, 3, 21, 42

rulemaking for repositories and disposal, 46

site characterization, Point Papers, 18, 28

testimony before, 27

Nuclear Waste Fund (see Funding)

Nuclear Waste Policy Act, 32

amendments to

(see Nuclear Waste Policy Amendments Act)

(see Public Laws)

passage of, 1

provisions of, 1,32

Sections

111,37

113,55

$116,2,8,52$

$117,24,29$

$118,2,8$

121,55

149,2

$175,15,61,62$

180,26

223,15

$301,8,31$

302,37

304,39

Nuclear Waste Policy Amendments Act of 1987 $1,8,24,34$

Benefits Agreements, 29

financial assistance, 29

NRC role, 46

onsite representation, 24

phaseout and reclamation activities, 21

prenotification, of waste shipments, 25 
Sections

$5011,8,24$

5031,24

5032,8

5033,8

$5064,20,39$

schedule of, table 10

Nuclear Waste Technical Review Board, 2, 10

Nye County, Nevada, 52

\section{Oak Ridge National Laboratory, 26}

\section{Offices}

Civilian Radioactive Waste Management, 19, chart 19

Chicago Operations, 25

Defense Programs, 45

External Relations and Policy, 18, 42

Facilities Siting and Development, 18

Geologic Repositories, 17

Idaho Operations, 25, 38, 41

Management and Budget, 28

the Negotiator, 2, 52

Nevada Operations, 24

Nevada Waste Management Project, 17, 32,38

Oak Ridge Operations, 25

Program Administration and Resource

Management, 18

Quality Assurance, 19, 28, 34, 42

State of Nevada Nuclear Waste Project, 18

Systems Integration and Regulations, 18

Subseabed Research, 3

(see also Appointments)

\section{Onsite representation, 24}

Pacific Northwest Laboratory, 40

Pacific States Agreement on Radioactive Materials Transport Management, 33

Prenotification, of waste shipments, 26, 45

Program planning, 16

Strategy Options Document, 4
Public Laws

100-203, 1

$100-371,43$

$100-507,52$

Public Participation

cask design, 41

draft Mission Plan Amendment, 44

dry cask storage, $20,39-40,42$

financial assistance, 29

monitored retrievable storage program, 16, 49

onsite representation, 24

repository program, $24,28-29$

Site Characterization Plan, 15, 17-18, 28-29, 55, 57-58

transportation program, 23, 25, 26, 45, 47

Quality Assurance

coordinating group, 35

Level I and II monitoring, 38

Office of, organization, 19, 34

Office of, Director of, 28, 34, 42

Nevada Nuclear Waste Storage Investigation

Quality Assurance Plan (NNWSI 88-9), 50, 52

planning, 52 (see also Reports)

program objectives, $28,34-36,53$

Quality Assurance Coordinating Group, 35

Quality Assurance Requirements document, 50

Quality Assurance Program Description, 50, 52

requirements, $42,50,52$

stop work order, 38

training for, $34,52-53$

Quality control, 32-33

Radiation doses, in transportation, 40

Reclamation Program and Implementation Plan 60

\section{Regulations}

for disposal of Greater-than-Class-C Low-Level Waste, 46

Environmental Regulatory Compliance Plan, 60 for geologic repositories, $46,55-56$

quality assurance, 50 


\section{Reports}

ALARA--Analysis of Radiation Doses from

Operation of Postulated Commercial Spent Fuel

Transportation Systems, 40, 41

Annual Capacity Report, 36

Dry Cask Storage Study, 20, 39-40

environmental documents, figure 63

Environmental Field Activity Plans, 51

Environmental Impact Statement Implementation Plan, 60

Environmental Monitoring and Mitigation Plan, $12,15,60$

Environmental Program Overview (draft), 60

Environmental Regulatory Compliance Plan, 60 draft, 12

Licensing Support System (LSS)

Benefit-Cost Analysis, 28

Conceptual LSS Design, 28

Preliminary Needs Analysis, 28

Preliminary Data Scope, 28

MRS Review Commission Report, 52

Nevada Nuclear Waste Storage Investigation

Quality Assurance Plan, 50, 52

Nuclear Regulatory Commission

Point Paper, 18, 27

OCRWM Annual Report to Congress, 39, 41

Quality Assurance Program Description

Document, 50, 52

Quality Assurance Requirements, 50

Reclamation Program and Implementation Plans, 60

Safety Analysis Report on Packaging, 38

Section 175 Report, 61

Site Characterization Plan Overview, 59

Site Characterization Plan Public Handbook for

Yucca Mountain, 57

Socioeconomic Monitoring and Mitigation Plan, 12,61

Transportation Business Plan, amendment, 4-5

\section{Repository}

authorization procedures for, 56,60

first repository, 1, 14-15

schedule, table 14

performance allocation in design, 27

review procedures for, 46

second repository, 2,15

\section{Research and Development}

air quality research, 51

Civilian Radioactive Waste Research and

Development program funding request, 17

cooperative demonstrations, 17

cultural resources studies, 51

dry cask storage (see Storage, dry cask)

Energy Supply Research and Development

Program, 13

Exploratory Shaft Facility, 50

International programs, 15

Office of Subseabed Research, 3

radiological studies, 51

subseabed disposal, 2-3

surface-based testing, 15

terrestrial ecosystems studies, 51

\section{Right-of-Way Reservation (ROWR), 7-8}

\section{Sandia National Laboratories, 32}

\section{Schedule}

Exploratory Shaft Facility, 50

Monitored Retrievable Storage Review

Commission, 49

report due date extended, 52

Nuclear Waste Policy Amendments Act of 1987, 10

OCRWM program milestones, tables 41, 50

repository, table 14

Science Applications International Corporation, 3,32

\section{Section 175 Report, 61}

Site Characterization Plan (SCP), 14-15, 32, 44, 55-59, illus. 59

alternative conceptual models, 18, 28, 44

applicable regulations, $32,46,55$

concurrent activities, 33

Consultation draft, 15, 17-18, 27, 44, 57

Overview, 12

purpose of, 57

review and comments, 44

technical review by NRC, 18

disqualification, procedures in event of, 56

Exploratory Shaft Facility, schedule for, 50, table 50 
legislative and regulatory requirements, 55,57

overview, 59

organization for completion, 32, chart 32

organization of, 56

quality control, 32-33

SCP Program Review Board, 32

SCP Integration Groups, 32

SCP Working Groups, 32

Public handbook, 57

public participation, $17-18,55,57-58$

purpose of, 59

Safety Analysis Report, 44

Site Characterization Program, 14, 44

characterization activities, 44

description, 7, 32, 55-56

model development, 44

organization of, illus. 56

physical characterization, 44

process, 56

purpose, 44

Nevada Nuclear Waste Site Investigation, 38

Southern States Energy Board (SSEB), 25

Standard Contract for Disposal of Spent Nuclear

Fuel, 36

\section{States}

Tennessee, 3

Nevada, 15, 17, 18, 24, 28, 39, 43, 51, 57

Louisiana, 8, 21

Mississippi, 8, 21

Texas, 8,21

Utah, 8, 21

Washington, 8, 21

Stop-work order, 38

Storage, at-reactor requirements, map 39

Storage, dry cask

study, 16, 20, 27, 39-40, 47

funding, 20

public participation, $20,39-40,41,42$

Storage, Federal Interim, 11, 25-26

Subseabed disposal, 2-3, 10
Surface-based Testing, 15

Systems Engineering Development and

Management (SEDM), 20

Systems Integration, 16

Technical Review

Nuclear Regulatory Commission, 18

Nuclear Waste Technical Review Board, 2

Testimony, Congressional, by C. E. Kay, 23, 26-29

Nuclear Regulatory Commission presentation, 27-29

transportation program, $23,26-27$

\section{Training}

for public safety officials, 26

in Quality Assurance program, 34

\section{Transportation}

ALARA principles, 40

analysis of radiation doses in, 40

Business Plan; 4

cask development

background, 4, 25, 26- 27

cask description, illus. 26

contractors named, 38

dual-purpose casks, deferral of, 4-5, 38

from-reactor casks, 4, 25, 26, 38, 41

legal-weight truck casks, 25, 27, 38, 47

opportunities for public input, 41

overweight truck casks, 38,40

$\mathrm{rail} /$ barge casks, $5,25,27,38$

cask maintenance facility, 25, 27

computerized programs and data bases, 26

cooperative agreements, 25,45

emergency response, 25,26

funding, 16

institutional issues, 23,47

Institutional Plan, 23

legal weight truck shipments, 4, 5

objectives, 27

overweight truck shipments, 4-5, 45, 47

pilot test, 33

plans, 16

Risk and Cost Analysis Model, 45

routing, 23, 26 
satellite tracking of shipments, 45

shipping campaigns, lessons learned, 47

training assistance, public safety officials, 26

uniform permitting system, 45

vehicle inspection, 33

Transportation Coordination Group, 4, 25, 41

TRANSCOM (satellite transportation, tracking and communication system), 45

TRICAM (Transportation Risk and

Cost Analysis Model), 45

U.S. Geological Survey, 32, 38, 57

USGS Southern Great Basin Seismic

Monitoring Network, 27

Utilities Nuclear Transportation Group, 33

Utility Nuclear Waste Management Group, 57

Virginia Power, 17

Waste Isolation Pilot Plant, 45
Western Interstate Energy Board (WIEB), 25,33

Westinghouse Electric Corporation, 38

Workshops

alternative conceptual models, 18,28

NRC Draft Point Paper, discussion of, 18

emergency preparedness, 25,26

Yucca Mountain Project, 50, 58

Project Update Meetings, 58

\section{Yucca Mountain Site}

Amendments to NWPA, 1

Environmental Field Activity Plans, 51

Environmental Program Overview (draft), 60

Exploratory Shaft Facility, 50

Right-of-Way Reservation, 7

Section 175 Report, 61

Site Characterization Plan

(see Site Characterization Plan)

Site Characterization Plan activities, 44

Site Characterization Plan, Consultation draft, 17

Site Characterization Plan process, 32, 55, 56

State on-site representative, 24 